\title{
Size and Liquidity Effects in Asia-Pacific equity markets
}

\begin{abstract}
This study contrasts the effectiveness of the capital asset pricing model (CAPM) against more recent augmented variants including size and book-to-market factors (Fama and French, 1993) as well as both size and liquidity factors of Martinez et al (2005) in explaining average returns in industry portfolios across a comprehensive sample of Asia-Pacific equity markets. Size and especially liquidity effects were found to be pervasive across national industry portfolios which were further supported through the application of Kalman filter time varying techniques. The evidence suggests that there are distinct similarities between the determinants of returns in both Chinese exchanges, namely Shanghai and Shezen, the markets of Singapore and Malaysia also have common determinants in their returns. Estimates of cost of equity across industries reveals that Japan is lowest followed by Australia, New Zealand, Singapore, Malaysia, Hong Kong and South Korea. The emerging markets of Thailand, Indonesia and Philippines together with both
\end{abstract} Chinese exchanges have the highest values.

\section{INTRODUCTION}

The established asset pricing model of Sharpe (1964) and Lintner (1965) has come to dominate the literature during the course of the last forty years and is routinely used by academics and practitioners in relating average returns to risk. The core prediction of the model is that the market portfolio of invested wealth if mean-variance efficient (Markowitz, 1959) inferring firstly that expected returns on securities are a positive linear function of their market betas (namely the slope or gradient in the regression between a security's return and those of the market) and secondly that these betas fully describe the cross section of expected returns (Fama and French, 1992).

While pricing theory states that the cross section of expected stock returns are related to the returns' sensitivities to state variables, which themselves are linked to investor welfare, there is interest in the nature of the state variables themselves. Fama and French (1993) (henceforth FF) first proposed that variations in size, defined as the valuation differences between value and growth stocks, and variations in accounting book value and market value of stocks are two such candidates for state variables. Furthermore, supplementing the traditional CAPM with two additional returnsbased factors representing these state variables provided improvements over the simple marketfactor alone. More recently, liquidity has been proposed as a state variable with a range of methods cited for its measurement. Pastor and Stambaugh (2003) found evidence of increased support for a trading volume based-liquidity factor augmenting the FF model, while Liu (2006) introduced a new trading speed measure designed to capture both traded turnover as well as frequency of trading as elements of liquidity. Furthermore, Liu (2006) found evidence that the addition of the single 
liquidity factor alone to the traditional CAPM generated increased explanatory power in excess of either the one factor CAPM or the FF model.

However there is a lack of evidence across the wider Asia-Pacific region concerning the benefits of including both the FF size and book-to-market factors in modelling the cross section of stock returns with focus being made on single individual markets such as Australia (Brooks and Faff (1998); Chan and Faff (2003)) and Japan (Chang et al, 2010). The presence of size effects is especially likely across the Asia-Pacific region given the wide dispersion of markets ranging from the highly developed Tokyo exchange to emerging markets such as China, dominated by state ownership (Ng et al, 2009), Thailand, dominated by family groups (Bertrand et al, 2008), as well as Indonesia and Philippines that are characterised by a wide dispersion of listings from larger internationally focussed firms as well as indigenous small and medium enterprises (SMEs) (Bowe and Domuta, 2004). However a large body of literature has emerged during the last two decades citing the importance of liquidity in affecting returns within Asia-Pacific markets although this is largely focussed on individual national markets rather than on a regional aggregate measure. Narayan and Zheng (2010) find evidence of a market-wide aggregate liquidity factor in the Chinese stock market, while Chang et al (2010) empirically contrast the liquidity constructs of Liu (2006) and Amihud (2002) in the Tokyo stock exchange. Aitken and Comerton-Forde (2003) contrast order and trade-based liquidity measures and their effectiveness in capturing liquidity effects in Jakarta stock exchange. Similarly Pukthuanthong-Le and Visaltanachoti (2009) find evidence of communality in liquidity in Thailand while Chan and Faff (2003) find evidence that liquidity is a priced anomaly in Australian stock returns. Consequently this study investigates whether size and liquidity effects are priced in these markets. The issue is whether differences in cross sectional expected returns can be better explained by including factors accounting for the differences in aggregate market-wide size and liquidity effects than simply the market factor of the traditional CAPM.

Liquidity as a concept is very hard to define largely because its characteristics transcend a number of transactional properties of markets including tightness, depth, resilience (Lesmond, 2005) and information (O'Hara, 2003). The literature has traditionally been limited in only using constructs that capture only one dimension of a multidimensional phenomenon. This typically centres on variants of the bid-ask spread (quoted or effective) in Amihud and Mendelsen (1986), the turnover measure of Datar et al. (1998), or measures relating to the price impact arising from traded volume such as Amihud (2002) and Pastor and Stambaugh (2003). However, there is very little published research concerning measures capturing the trading speed dimension of liquidity, defined as the ability to transact large quantities quickly with little price impact (Liu, 2006; Pastor and Stambaugh, 2003). Furthermore, there are serious concerns over the ability of existing onedimensional constructs to fully capture liquidity risk and their inaccurate estimation of the dimension they are intended to model (Pastor and Stambaugh, 2003; Amihud, 2002). Equally 
deficiencies in the application of the bid-ask spread measure have been highlighted in Lee (1993) where evidence reveals that many large trades occur outside the bid-ask spread while many small trades are undertaken within it, leading to potential bias. Further concerns over the application of one-dimensional measures focus on the fact that they are undefined in the presence of extremes of illiquidity, as is frequent in smaller regional markets (Lesmond, 2005). A more recent measure developed by Liu (2006) captures the trading speed dimension of liquidity, defined as the standardized turnover-adjusted number of zero trading volumes over the past twelve months. It is multi-dimensional and captures effects relating to trading speed, trading quantity and trading cost, with an emphasis on trading speed, defined as the continuity of trading and the potential delay in executing an order (Liu, 2006). An additional benefit from this measure arises is its robustness in the presence of significant illiquidity (Liu, 2006), again as is often present in emerging markets (Hearn and Piesse, 2009).

The literature concerning the inclusion of liquidity as a priced state variable in a valuation framework is very recent. Pastor and Stambaugh (2003) find strong evidence from US stock data that market-wide liquidity is a priced state variable and that it should be positive. The study applied the innovations of a price impact measure of liquidity to sort stocks within a universe into decile portfolios with the market aggregate premium formed by the difference between returns of the highest and lowest liquidity deciles. The explanatory power from including this fourth fact was established by comparison with the Fama and French (1993) three factor model and the traditional CAPM. Stocks with higher sensitivity to aggregate liquidity stocks compensate investors with higher expected returns. Evidence is also found that small stocks have greater sensitivity to liquidity innovations than large stocks. Pastor and Stambaugh (2003) note that intuitively it could be expected that small and illiquid stocks are those most affected by market aggregate drops in liquidity and this causes investors to flee to assets with higher liquidity. However, their findings also show that size and liquidity are not the sole determinants of liquidity betas. This is reinforced by the argument that stocks with a high liquidity beta are not necessarily illiquid. Investor preferences when there are market aggregate falls in liquidity are also likely to focus on rival bond markets. In order to increase portfolio holdings in bonds investors may seek to sell liquid stocks in order to save on transactions costs. Consequently in this scenario the price reaction to aggregate liquidity changes is stronger for more liquid stocks. Equally, prices of liquid stocks could have greater sensitivity to aggregate liquidity shocks if such stocks are held in greater proportions within the portfolios of liquidity-conscious investors. Thus, Pastor and Stambaugh (2003) find little basis for liquidity betas to bear a simple relation to stock size and liquidity. Liu (2006) builds on this first using a new liquidity construct to estimate stock liquidity and then including this factor within a two factor augmented CAPM. While the additional liquidity factor offers strong performance in explaining the cross section of US stock returns the results contradict earlier findings of Pastor and 
Stambaugh as the liquidity premium alone incorporates anomalies such as size and the book-tomarket effects in Fama and French (1993).

However extensions of the CAPM in including liquidity measurement tend to be restricted to individual national markets and lack wider regional focus while only Brooks et al (1998) consider the modelling of industry portfolios with this being solely focussed on Australia. Consequently the motivation here is to focus on the wider Asia-Pacific region in looking for communality in size and liquidity effects. A unique perspective on individual industry sectors is provided that justify the consideration of stocks that are constituent members of blue chip indices as these are most likely to satisfy the asset market integration and informational assumptions inherent in the CAPM and are of most interest to overseas investors.

The majority of the valuation literature on pricing models assumes a time invariant relationship in the systemic risk of an asset. However, a separate literature addressing the time varying nature of systemic risk has evolved because of an increasing concern about the violation of assumptions inherent in the linear model, such as normality, identity and independence of stock returns (Grout and Zalewska, 2006). Pettengill et al (1995) and Ho et al (2006) studied the relationship between risk and return in "up" as opposed to "down" markets while Bekeart and Harvey (1995) undertook a similar study using Markov-switching regressions across a sample of emerging markets to examine differences between periods of integration with world markets and segmentation. More recently Watanabe and Watanabe (2008) incorporate a Markov-switching regime model to account for a time varying liquidity premium across a universe of US stocks. However Brooks et al (1998) used time varying techniques based on the Kalman-filter approach applied Australian industry portfolios and found that these techniques produced improved in and out of sample performances than other econometric techniques. Grout and Zalewska (2006) find that the use of Kalman filter methods is preferable to Markov-switching regressions as it was not necessary to define the exact point of the switch (Grout and Zalewska, 2006). Instead any changes in the time path of betas can be assessed using regression results, which is particularly relevant in modelling liquidity effects in the presence of the fluctuation within emerging markets. Thus, following Brooks et al (1998), this paper uses time varying techniques and the Kalman filter.

The results show that aggregate size and liquidity effects are significant in industries across individual national markets across the Asia-Pacific region. The inclusion of size and liquidity is preferable to the FF size and book-to-market value factors in offering enhanced explanatory power in capturing the cross section of average stock returns. Similar results are found using the time varying techniques. However there are considerable variations across the wider Asia-Pacific region as would be expected in a region of this breadth and diversity. Substantial differences exist between both Chinese markets of Shanghai and Shenzen with Hong Kong where size and liquidity effects in industries in the former two Chinese markets are very similar in size, direction and statistical significance while size in particular is less important in explaining Hong Kong returns. 
Equally there is evidence of similarly sized and significant liquidity effects between the Malaysia and Singaporean financial sector with both having been affected by the recent global financial crisis and recession. There is also some evidence too of a sharp increase in illiquidity in Thailand's stock market during the initial period of civil and political unrest in 2009. Costs of equity, estimated from a US investor viewpoint, support the dominance and international competitiveness of blue chip firms in Japanese industries while the markets of Australia, New Zealand, Singapore, Malaysia and Hong Kong remain competitive in sourcing finance. The least competitive industrial sectors are those of Philippines, Thailand, and both Chinese markets of Shanghai and Shenzen which in part is supported by the literature (da Veiga et al (2008); Narayan and Zheng (2010)). Overall these results lend further support for the use of the mean-variance theory in an emerging market context.

The paper is structured as follows. Section 2 reviews the institutional features of Asian and Australasian equity markets, describes the construction of the liquidity measures and provides descriptive statistics of the data used. Section 3 outlines the two modelling approaches: the size and liquidity augmented CAPM and its time varying parameter equivalent. Section 4 discusses the results and the final section concludes.

\section{ASIA-PACIFIC EQUITY MARKETS AND LIQUIDITY MEASUREMENT}

\subsection{Australia and New Zealand}

The modern Australian stock exchange (ASX) is the result of the integration of six regional stock exchanges located in each of the state capitals. The Sydney exchange was first to be established in 1871, followed by the Hobart (in 1882), Melbourne and Brisbane (in 1884), Adelaide (in 1887), and Perth (in 1889). National integration of individual state-focussed regulatory regimes was achieved in 1937 (ASX website, 2009) while the six exchanges finally merged in 1987 to form the Sydney based ASX. The SEATS (Stock Exchange Automated Trading System) trading system was adopted for all trading in 1990 following the closure of the exchange open outcry floor with the exchange demutualising in 1996. The Australian Securities and Investments Commission is responsible for regulation while the ASX owned Austraclear operates clearing, settlement and payments at a national level (ASX website, 2009). The evidence from Table 1 reveals that market capitalization and traded value is more concentrated on financial and basic materials sectors while Appendix Table 1 reveals that regulatory and listings requirements are particularly onerous for this market inferring the adoption of high international standards.

The New Zealand stock exchange (NZX) is based in Wellington and consists of three principal market segments: the stock exchange (NZSX), alternative exchange (NZAX) and debt market (NZDX), which is further subdivided into the NZFOZ which is responsible for derivatives products (NZX website, 2009). The NZX traces its origins to the 1970's gold rush period and the establishment of informal markets in the major regional towns and cities which had been organized 
into formal exchanges by 1915 . These were integrated in 1974 to form the modern NZX which was de-mutualised in 2002 (NZX website, 2009). Trading has been electronic since 1991 and the systems were substantially improved in 1999 (NZX website, 2009). The NZSX has a more dispersed profile than its Australian neighbour (see Table 1) with capitalization in particular spread between industrial, financial, communications, consumer cyclical and consumer non-cyclical sectors fairly evenly. Traded value is slightly more focussed between communications, consumer cyclical and industrial sectors.

\section{Table 1}

\subsection{Indonesia}

The modern Indonesia Stock Exchange (IDX) was established in 2007 following the merger between the Surabaya stock exchange (SSX) itself established in 1989, and the Jakarta stock exchange (JSX), originally created in 1912. While trading has been electronic since inception this is based on the Jakarta Automated Trading System (JATS) originally established in the JSX in 1995. Following the earlier JSX the exchange is de-mutualised and under the regulatory surveillance of the Capital Market Supervisory Agency (IDX website, 2009). Table 1 reveals that while capitalization is reasonably dispersed with $25.09 \%$ in financial sector followed by $12.82 \%$ in communications, $16.17 \%$ in basic materials, $14.97 \%$ in consumer non-cyclical and $12.93 \%$ in industrial sectors the traded value is much more focussed with $42.31 \%$ being in basic materials, $16.09 \%$ in financial and $13.05 \%$ in industrial sectors. This indicates that the top tier blue chip stocks in Indonesia are primarily basic materials and mining firms.

\subsection{Singapore and Malaysia}

The Singapore Stockbrokers Association was established in 1930 and subsequently re-branded as the Malayan Stockbrokers Association seven years later. The Stock Exchange of Malaysia was established in 1964 with trading boards between Singapore and Kuala Lumpar (KLSE website, 2009). The independence of Singapore and 1973 secession of currency interchange ability between the Malaysian Ringgit and Singapore Dollar caused the de-merger of the two exchanges with the Stock Exchange of Singapore and Kuala Lumpar Stock Exchange (KLSE) being newly created. The KLSE changed to the present Bursa Malaysia following its 2007 de-mutualisation. Trading is electronic and a CDS enables the market to achieve international standards in clearing and settlement (KLSE website, 2009). The modern Singapore stock exchange (SGX) is the result of a 1999 merger between the Singapore International Monetary Exchange and the Stock Exchange of Singapore, where the history of the latter is detailed above. The SGX is the Asia-Pacific's first demutualised and integrated securities and derivatives exchange (SGX website, 2009). The evidence from Table 1 reveals that there are considerable similarities between both Singapore and Malaysia with their financial sectors having the greatest proportion of capitalization $(35.94 \%$ and $33.21 \%$ 
respectively) and traded value (36.65\% and $34.78 \%$ respectively) followed by consumer noncyclical sector which has capitalization of $18.66 \%$ in former and $17.82 \%$ in latter. There is a marginally higher concentration in communications sectors in Singapore while there is a greater focus in diversified and utilities in Malaysia. Overall these results indicate that the dispersion of blue chip stocks between both markets is broadly similar across industrial sectors.

\section{$2.4 \quad$ Thailand}

The Stock Exchange of Thailand (SET) was established in 1974 following the demise of the original Bangkok stock exchange which failed largely due to a lack of domestic investment culture and lack of government support. The exchange operates an electronic trading system (Automated System for the Stock Exchange of Thailand (ASSET)) which is split into two compartments: Automatic Order Matching (AOM) and Put-Through transactions (PT). AOM is further split into a continuous auction for more liquid securities and a sequence of call auctions for those less frequently traded stocks (SET website, 2009). In contrast the PT system allows functions as a broker-dealer market and permits trading to occur by agreement between buyers and sellers where the effective executed price may not be the same as that advertised and may not follow the price spread rules. The market also has a well developed circuit-breaker where trading is halted should the SET Index fall by more than 10\% from the previous day closing value (SET website, 2009). The market has a highly concentrated profile in both capitalization and traded value with financial and energy sectors dominating with a combined total of $57.89 \%$ capitalization and $61.90 \%$ traded value.

\subsection{Hong Kong and China (Shanghai and Shenzen)}

The Hong Kong Stock Exchange traces its origins to the 1891 Association of Stockbrokers in Hong Kong which was renamed in 1914 as the Hong Kong Stock Exchange (HKSE) in the British protectorate of Hong Kong. A series of complex mergers with other smaller exchanges in Hong Kong between 1947 and 1986 resulted in the HKSE monopolising the market. The modern form of the HKSE is from a final merger in 2000 with the Hong Kong Futures Exchange and the Hong Kong Securities Clearing Company. While the HKSE first introduced a computer assisted trading system to the market as early as 1986 the electronic "Automatic Order Matching and Execution System" (AMS) was formally introduced in 1993 which was substantially improved to replace open outcry trading in 2000 (HKSE website, 2009). The market adheres to the self-regulatory model of regulation with legal system closely related to English common law largely due to the recent 1997 relinquishment of the city state to Chinese rule. Table 1 reveals that concentration of capitalization and traded value is in financial sector followed by communications and energy industries. A total proportion of $42.63 \%$ capitalization and $37.41 \%$ traded value is in financial sector stocks. 
The two other Chinese stock exchanges, in Shenzen and Shanghai, are fundamentally different in their design and operation than that of Hong Kong and were jointly established in 1990. The Shenzen stock exchange (SZSE) was established as part of the Chinese socialist government's reform process. However despite the considerable size of the market the Chinese government retains a sizeable controlling interest in the majority of listed firms and until very recently in 2005 over $66 \%$ of shares were non-tradable on the exchange. Trading is by electronic continuous auction with settlement undertaken through a CSD (SZSE website, 2009). The profile of the market is similar to that of Shanghai where a handful of industries account for the majority of capitalization and traded value. The financial, basic materials, consumer cyclical and consumer non-cyclical sectors jointly account for $76 \%$ of total market capitalization and over $70 \%$ traded value which with the exception of the financial sector is markedly different from Hong Kong.

The Shanghai stock exchange (SSE) trades three principal types of security: stocks, debt and funds. However in line with Shenzen the government maintains considerable control over the market both directly and indirectly through strict capital account controls making foreign investment and repatriation of profits difficult. Furthermore there are two types of share issued and traded on the SSE, namely "A" and "B" shares with the former being quoted in local currency and later in US\$ in turn reflecting that the former are restricted for Chinese nationals only while the latter are open to both local and foreign investors (SSE website (2009); Cai et al (2005); da Veiga et al (2007)). Reforms in 2002 were implemented where foreign investors qualifying under the Qualified Foreign Institutional Investor (QFII) program are able to also participate in the trading of "A" shares although trading activity is subject to pre-set quotas reflecting continued influence of government over the market (SSE website (2009); Cai et al (2005); da Veiga et al (2007)). The evidence from Table 1 shows that in line with Shenzen capitalization and traded value are focussed in financial, basic materials, consumer cyclical and consumer non-cyclical industries.

\subsection{Philippines}

The Philippine stock exchange was established from the 1992 merging of the much older Makati stock exchange, established in 1963, and Manila stock exchange, founded in 1927 which served distinct business districts within the Philippines capital, Manila (PSE website, 2010). Since the merger two trading floors are maintained in the Makati and Pasig city areas of Manila which are linked through a common electronic trading platform and a central depository itself established in 1995. The merged exchange and wider market is subject to self-regulation under the supervisory oversight of the Philippines Securities and Exchange Commission. The PSE maintains three listing boards, the first, second and Small and Medium Enterprises Board with an overview of listings criteria provided in Appendix Table 1. The profile of the constituents of the top tier blue chip Thomson Reuters TRX index reveal that there is heavy concentration in capitalization between financials, communication and industrial sectors with the financial sector dominating at $36.83 \%$. 
Similarly there is considerable concentration in proportion of traded value with this being dominated in particular by financial sector $(36.52 \%)$. The dominance of the financial sector in smaller emerging markets such as the Philippines is intuitively expected owing to regulatory requirements ensuring banking industry diversification of capital and deposit insurance in the form of equity.

\subsection{Japan and South Korea}

The modern Tokyo stock exchange (TSE) traces it's origins to a much older Tokyo Stock Exchange Company Ltd that was established in 1878. This became the centre of the wartime Japan Securities Exchange itself established in 1943 through the merging of the then eleven regional Japanese stock exchanges. This was dissolved in 1947 with the current TSE being created in 1949 (TSE website, 2009). Open outcry trading was replaced by an electronic continuous auction system in 1999 and the exchange de-mutualised in 2001 changing its status from an incorporated association with its members as stakeholder to a joint stock corporation (TSE website, 2009). Trading is remote and from $9 \mathrm{am}$ to $11 \mathrm{am}$ and $12-30 \mathrm{pm}$ to $15-00 \mathrm{pm}$ across the three market segments: the first and second tiers and the Tokyo Mothers Board ("Market of high-growth and emerging stocks") which is the development market (TSE website, 2009). The profile across the TOPIX-100 market barometer index composed of blue chip stocks reveals significantly greater dispersion than in any other AsiaPacific regional market. However financial sector still accounts for $15.36 \%$ capitalization while the consumer cyclical and industrial sectors account for $20.34 \%$ and $22.46 \%$ proportion of capitalization respectively. Similarly traded value is evenly spread across sectors though with some focus on these three sectors too.

The Daehan Stock Exchange, the predecessor of the modern Korea Stock Exchange (KSE), was established in 1956 which was reorganized into a joint-stock company in 1962 before undergoing further reorganization as a not-for-profit government run organization the following year (KSE website, 2010). Trading is electronic and settlement confirms to international best practice. The profile in Table 1 reveals that while financial sector accounts for $17.04 \%$ of capitalization, the technology and industrial sectors account for $32.45 \%$ and $27.15 \%$ capitalization respectively. Similarly the three sectors account for a total $80.58 \%$ traded value. This would indicate the greater emerging market character of the exchange in contrast to its highly developed neighbouring exchange in Tokyo.

\section{(ii). Liquidity constructs}

\section{The Bid Ask spread and commission cost}

The Bid-Ask spread and commission cost: The bid-ask spread is calculated using the average of the available monthly quotes and incorporates at a minimum a single month's quote for that month. 
The average bid-ask spread spanning the quarter is used for the estimate of the spread. This procedure minimizes outliers and averages out the recording of either highs or lows in quotes resulting from monthly sampling. Following Lesmond (2005) bid-ask spreads that exceed $80 \%$ are trimmed as these are potentially errors. The monthly quoted spread is defined as:

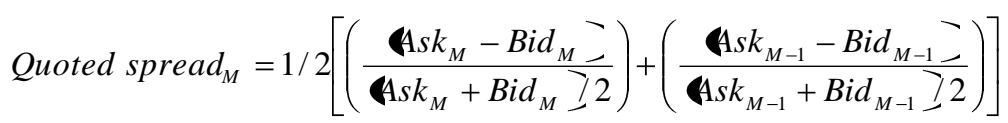

\section{Liu (2006) measure}

The measure is from Liu (2006) and defined as $\mathbf{L M}_{\mathrm{x}}$ which is the standardized turnover-adjusted number of zero daily trading volumes over the prior $\mathrm{x}$ months $(\mathrm{x}=1,6,12)$ i.e.

$L M_{x}=\left[\right.$ Number of zero daily volumes in prior $\mathrm{x}$ months $\left.\_+\frac{1 / \mathrm{x} \text { month turnover }}{\text { Deflator }}\right] * \frac{21 x}{\text { NoTD }}$

where $\mathrm{x}$ month turnover is the turnover over the prior $\mathrm{x}$ months, calculated as the sum of the daily turnover over the prior $\mathrm{x}$ months, daily turnover is the ratio of the number of shares traded on a day to the number of shares outstanding at the end of the day, NoTD is the total number of trading days in the market over the prior x months, and Deflator is chosen such that,

$0<\frac{1 / \text { month turnover }}{\text { Deflator }}<1$

for all sample stocks ${ }^{1}$. Given the turnover adjustment (the second term in brackets in first expression), two stocks with the same integer number of zero daily trading volumes can be distinguished: the one with the larger turnover is more liquid. Thus, the turnover adjustment acts as a tie-breaker when sorting stocks based on the number of zero daily trading volumes over the prior $\mathrm{x}$ months. Because the number of trading days can vary from 15 to 23 , multiplication by the factor (21x/ NoTD) standardizes the number of trading days in a month to 21 , which makes the liquidity measure comparable over time. LM1 can be interpreted as the turnover-adjusted number of zero daily trading volumes over the prior 21 trading days, which is the approximate average number of trading days in a month. The liquidity measure, $\mathbf{L M}_{\mathrm{x}}$ is calculated at the end of each month for each individual stock based on daily data. Daily data is available for all markets across the sample period.

(iii). Data: Sources

Daily stock closing, bid and ask prices, total number of shares outstanding, traded volumes, dividend per share in local currency and converted into US\$ were obtained for all markets from

${ }^{1}$ Following Liu (2006) a deflator of 11,000 is used in constructing estimates for LM1 
Datastream. These data formed the basis of calculation of the daily return variance (volatility), market capitalization, defined as total number of shares outstanding multiplied by daily closing price, and various liquidity constructs. The total returns series for each stock were also from Datastream for all markets as were local currency to US\$ exchange rates and 10 year US Treasury Bill yield data. The 10 year US Treasury Bill yield rate represents the risk free rate although this is adjusted to take account of monthly excess returns as opposed to the quoted equivalent annualised rates. The conversion of the total returns series and prices into US\$ and the use of US Treasury Bill yield rate assume long term parity between local currencies and US\$. All estimation was in US\$ in line with asset pricing literature. Finally only primary listed stocks were included with those being constituent to the top tier blue chip indices in each market in order to satisfy the concept of investibility as well as issues regarding potential segmentation through the selection of wider universes composed of smaller less liquid stocks within each country. These are the 100 constituent stocks of the Standard \&Poors (S\&P) ASX 100 in Australia, 133 constituents of NZSX All-Share in New Zealand, 45 constituents of the Jakarta 45 index in Indonesia, 177 constituents of TRX-Singapore, 100 stocks of the FTSE-100 in Malaysia, 100 constituents of SET-100 in Thailand, 201 constituents of Hong Kong Composite, China Shanghai 180, China Shenzen 100, 54 constituents of Thomson Reuters Top Philippines, TOPIX-100 in Japan and finally the KOSPI-100 in South Korea.

\section{(iv). Data: Summary statistics}

There are considerable differences both across industries within and between individual markets in the Asia Pacific region as reflected in Table 2. The average firm size, or market capitalization in US\$ is largest in the major global markets of Japan and then Australia which is partly a reflection of onerous regulatory and corporate governance requirements for which constituent firms are subjected in order to maintain a listing in the top tier blue chip indices in both markets. Equally these two markets have the lowest bid-ask spreads and the lowest average monthly daily zero returns providing further indication of the extremely high liquidity and lack of any price rigidity in these markets. New Zealand in contrast to its neighbour is a much smaller market as reflected in average capitalization or firm size across industries and has significantly higher illiquidity denoted in much higher percentage daily zero returns and bid-ask spreads with reduced traded volumes. The markets of Malaysia and Singapore together with both Chinese markets in Shenzen and Shanghai have similar average firm sizes across industries and levels of activity denoted by average percentage daily zero returns and bid-ask spreads. Industry characteristics are notably different in Hong Kong than either of the two mainland Chinese exchanges and while the average monthly percentage of daily zero returns and bid-ask spreads are higher across industries firm size is considerably larger, as in market capitalization, while traded volumes are comparable. The South Korean industries are broadly comparable in average firm size, monthly average percentage daily 
zero returns and bid-ask spread to the Japanese market while average firm size is considerably smaller. Finally industries in the Philippines stock market generally have the smallest average size, or market capitalization, least traded volume and the highest price-rigidity denoted by the average monthly proportion of daily zero returns although bid-ask spreads are comparable to markets such as Singapore and New Zealand.

\section{Table 2}

\section{MODELS}

This section considers time invariant coefficient and time varying coefficient modelling strategies. The former is further divided into one-factor CAPM, followed by the three-factor Fama and French (1993) model augmented by size and book-to-market value returns based factors and finally the three-factor size and liquidity augmented CAPM of Martinez et al (2005). The returns based factor mimicking portfolios used are generated through a two-stage sorting process for size and book-tomarket factors following Fama and French (1993) first sorting stocks constituent to market universe into five respective size portfolios and for each size portfolio into a further five book-to-market value portfolios in December of each year. The size and book-to-market factor is then constructed in accordance to Fama and French (1993) techniques. Finally the size and liquidity mimicking portfolios of Martinez et al (2005) follow the double-sorting procedure of Fama and French (1993) though this time first into three size based portfolios and then each into a further three illiquidity sorted portfolios, based on Liu measure. The resulting returns based factors are constructed in same manner as Fama and French size and book-to-market value factors. In addition to the returns-based factors individual national-market and industry portfolios were formed through sorting stock returns into simple price-weighted portfolios.

(i). Size and Liquidity Augmented CAPM

The standard capital asset pricing model (CAPM) of Sharpe (1964) and Lintner (1965) states that excess returns on a stock or portfolio of stocks are positively related to those of the market. Formally this is stated in expected returns:

$$
E \boldsymbol{C}_{p t} \supset r_{f t}=\beta_{M} \mathbf{E} \boldsymbol{\varangle}_{m t}-r_{f t}{ }_{-}^{-}
$$

where $r_{p t}$ is the returns on a portfolio $\mathrm{p}$ of stocks at time interval $\mathrm{t}, r_{m t}$ is the returns on market portfolio and $r_{f t}$ the risk free rate. This can be rearranged and estimated by OLS regression:

$$
r_{p t}-r_{f t}=\alpha_{i}+\beta_{M}\left(r_{m t}-r_{f t}\right)+\varepsilon_{i t}
$$


where $\alpha_{i}$ is the constant, or Jensen alpha, $\beta_{M}$ is market coefficient and $\varepsilon_{i t}$ is an independently identically distributed (iid) disturbance term.

Following Fama and French (1993) the one factor CAPM can be further augmented with expected returns attributable to size and book-to-market effects:

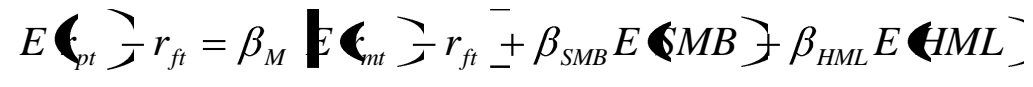

where the additional SMB and HML terms are the size and book-to-market factors. This can be rearranged and estimated by OLS regression:

$$
r_{p t}-r_{f t}=\alpha_{i}+\beta_{M}\left(r_{m t}-r_{f t}\right)+\beta_{S M B} S M B_{t}+\beta_{H M L} H M L_{t}+\varepsilon_{i t}
$$

In the spirit of the above Fama and French model the one-factor CAPM is augmented with size (SMB) and liquidity (ILLIQ) factors in order to create a size-liquidity three factor model, following Shum and Tang (2005) and Martinez et al (2005). Therefore, the expected excess returns on a portfolio $\mathrm{p}$ of emerging market stocks can be written as

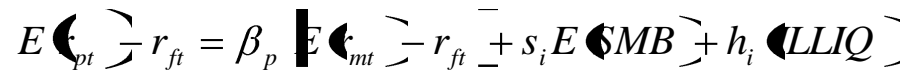

This can be transformed in order to test historical data into the following equation:

$$
r_{i t}-r_{f t}=\alpha_{i}+\beta_{i}\left(r_{m t}-r_{f t}\right)+s_{i} S M B_{t}+h_{i} I L L I Q_{t}+\varepsilon_{i t}
$$

where the variables are described above and $\varepsilon_{i t}$ is an independently identically distributed (iid) disturbance term. The model is estimated using time series Ordinary Least Squares (OLS) techniques, following Black, Jensen and Scholes (1972), in line with Fama and French (1993); Pastor and Stambaugh (2003); and Liu (2006)).. The expectation is that the Jensen alpha should not be statistically different from zero given the theoretical relationship between an individual portfolios expected returns and those of the market (Markowitz 1959). However, Scholes and Williams (1977) found that using standard OLS resulted in beta estimates that are biased downwards for securities infrequently trading and upwards for those traded more often. Dimson (1979) also found the beta estimate is inefficient in thinly traded stocks and proposes a correction technique based on the aggregation of betas from lagged and leading regression coefficients. Dimson and Marsh (1983) propose a second correction technique, which uses a trade-to-trade method measuring and matching returns between individual stocks or portfolios and the market index between the times of the last trades in successive months. The use of standard OLS here follows the work of Pastor and Stambaugh (2003), Liu (2006) and Martinez (2005) who use these techniques extensively in their studies involving multifactor CAPM models capturing liquidity effects. However the limitations of standard OLS must be taken into account particularly when 
applied to the smaller and significantly less liquid markets such as Philippines and especially Indonesia.

\section{(ii). Time varying parameter CAPM model}

Following Brooks et al (1998) the time varying parameter equivalent of the linear CAPM uses the Kalman filter and relies on the notion of state space to estimate the conditional constant term and market beta of the multifactor CAPM. This is represented by an observation equation and a transition or state equation, that in combination express the structure and dynamics of a time varying system. A state space model is specified where an observation at time $t$ is a linear combination of a set state variables, which compose the state vector at time t. Assuming the number of state variables is $\mathrm{m}$ and the $(\mathrm{m} \times 1)$ vector is $\theta_{\mathrm{t}}$ then the observation equation can be represented by:

$$
y_{t}=z_{t} \theta_{t}+\mu_{t}, \quad \mu_{t} \sim N\left(0, \sigma_{\mu}^{2}\right)
$$

where $z_{t}$ is assumed to be known ( $\left.\mathrm{mx} 1\right)$ vector, and $\mu_{t}$ is the observation error, which is assumed to be normally distributed with zero mean. The set of state variables is defined from the minimum set of information from past and present data and future values of time series are completely determined by the present values of the state variables (the Markov property). The state space model incorporates unobserved variables and estimates them with the observable model, in imposing a time varying structure of the CAPM beta. The conditional betas are estimated using the following observation equation:

$$
R_{i t}=\alpha_{t}+\beta_{i t}^{\text {Kalman }} R_{M t}+s_{i}{ }^{\text {Kalman }} S M B+h_{i}{ }^{\text {Kalman }} I L L I Q+\varepsilon_{t}, \quad \varepsilon_{t} \sim N(0, \Omega)
$$

where $\mathrm{R}_{\mathrm{it}}$ and $\mathrm{R}_{\mathrm{Mt}}$ are the excess returns on the individual portfolio and market portfolios at time $t$ and $\varepsilon_{t}$ is disturbance term. The exact form of the transition equation depends on the form of stochastic process the betas are assumed to follow and in this case a simple random walk is imposed as outlined in Brooks et al (2000). The transition equation is defined:

$$
\begin{array}{ll}
\alpha_{i t}^{\text {Kalman }}=\alpha_{i t-1}^{\text {Kalman }}+\eta_{\alpha t}, & \eta_{\alpha t} \sim N(0, Q) \\
\beta_{i t}^{\text {Kalman }}=\beta_{i t-1}^{\text {Kalman }}+\eta_{\beta t,}, & \eta_{\beta t} \sim N(0, Q) \\
s_{i t}^{\text {Kalman }}=s_{i t-1}^{\text {Kalman }}+\eta_{s t,} & \eta_{s t} \sim N(0, Q) \\
h_{i t}^{\text {Kalman }}=h_{i t-1}^{\text {Kalman }}+\eta_{h t,}, & \eta_{h t} \sim N(0, Q)
\end{array}
$$

Together equations 13 and the combination of 14 to 17 constitute a Kalman filter state space model. However, a set of prior conditional values are necessary to forecast the future value expressed as: 


$$
\begin{aligned}
& \alpha_{0}^{\text {Kalman }} \sim N\left(\alpha_{0}^{\text {Kalman }}, P_{0}\right) \\
& \beta_{0}^{\text {Kalman }} \sim N\left(\beta_{0}^{\text {Kalman }}, P_{0}\right) \\
& s_{0}^{\text {Kalman }} \sim N\left(s_{0}^{\text {Kalman }}, P_{0}\right) \\
& h_{0}^{\text {Kalman }} \sim N\left(h_{0}^{\text {Kalman }}, P_{0}\right)
\end{aligned}
$$

Brooks et al (1998) cite that this technique uses the first two observations to establish the prior conditions and then recursively estimates the entire series providing conditional estimates of $\beta_{i t}^{\text {Kalman }}, s_{i t}^{\text {Kalman }}, h_{i t}^{\text {Kalman }}$ and $\alpha_{i t}^{\text {Kalman }}$.

\section{RESULTS}

(i). Summary statistics relating to size-liquidity sorted portfolios

Table 3 presents the descriptive statistics for the nine size-illiquidity sorted portfolios and the returns-based valuation factors. The mean returns across all portfolios in panel A are positive while there is a noticeable decrease in standard deviation from small size portfolios to large size portfolios while there are negligible differences between low illiquidity portfolios and those of high illiquidity. Levels of skewness and kurtosis are generally not overly revealing in terms of likely non-Normality of returns distributions except in the case of the small size-high illiquidity portfolio, which has an excess kurtosis value of 9.26 mirrored by a Jarque-Bera statistic of 241.04 indicating a high degree of non-Normality in returns. However this would be intuitively expected in smaller and more highly illiquid firms (Pastor and Stambaugh, 2003). More generally the Jarque-Bera statistics are noticeably higher across all three small size portfolios than those of medium or large size indicating that returns are much more erratic for smaller sized firms than for firms with higher market capitalizations ${ }^{2}$.

The dispersion of stocks across portfolios caused by the size-liquidity sorting process in forming the nine portfolios can be seen in panel B. While there is a relatively even dispersion of stocks across all nine size-illiquidity sorted portfolios with an average of between 130 to 140 stocks in each portfolio there are considerable differences in stock dispersions by country. Australian stocks are noticeably concentrated in the two medium and large size but high illiquidity portfolios while Japanese stocks fall heavily into the two large size and medium and high illiquidity portfolios. The large size and low illiquidity portfolio in contrast is largely made up from Chinese Shenzen, Shanghai and Hong Kong stocks while New Zealand stocks are almost exclusively concentrated in the three small size portfolios though with an emphasis on the small size and low illiquidity

\footnotetext{
${ }^{2}$ Correlations between returns based factors were undertaken with results available from author upon request. However these revealed a general lack of correlation between any of the factors and low levels of statistical significance mitigating largely concerns over multicollinearity.
} 
portfolio. Malaysian stocks are generally dispersed amongst the small and medium size portfolios while those of Thailand and Philippines dominate the small size portfolios although the former tends to be focussed in high illiquidity portfolios while the latter is concentrated on low illiquidity portfolios. Overall these results provide a more direct contrast between the intrinsic characteristics of each of the regions markets with notable differences in particular between Australia and Japan, where the latter is more liquid than the former while both have the largest listed firms yet the two Chinese exchanges and Hong Kong have more activity reflected in domination of low illiquidity portfolios. The smaller emerging markets of Indonesia, Philippines, Thailand and Malaysia are generally dispersed amongst medium and small size portfolios.

The evidence from panel $\mathrm{C}$ regarding the descriptive statistics of the returns-based valuation factors reveals that both the FF size factor and the Martinez et al (2005) size factor returns are least Normal reflected in higher levels of excess kurtosis and large Jarque-Bera statistics ( 247.1 for the former and 245.1 for the latter). However it is notable that mean returns are negative in the FF constructed size factor and positive for the Martinez size factor. This would indicate the possibility of a reverse size effect with expected returns actually decreasing as firm size increases when using the FF constructed size factor. However while the mean returns on the illiquidity factor are positive indicating the possibility of a reverse liquidity effect, their median value is negative as would be expected with the difference in direction between the two values likely to be from nonNormality in liquidity factor returns. This is likely owing to the comprehensive nature of the sample through including smaller and less liquid markets such as Philippines and Indonesia.

Table 3

Table 4 presents the descriptive statistics for the industry sector portfolios for each market. These show that while mean returns for all industrial portfolios are positive their standard deviations are generally large. However the evidence is generally supportive of the earlier findings that industries in Japan and Australia have the lowest returns but matched by the lowest standard deviations (the risk measure) which are equally mirrored by low levels of excess kurtosis, skewness and JarqueBera statistics indicating a high degree of Normality in the distribution of returns. In contrast at the other extreme of non-Normality the industry returns across Indonesia and Philippines are generally higher but matched by substantial standard deviations (over 69\% in Philippine basic materials) and extremely high levels of skewness, excess kurtosis and Jarque-Bera statistics in the Philippines at 13,678 for basic materials and 3,749 for consumer cyclical. The only industry with more extreme deviations of non-Normality in returns is Thailand communications with a Jarque-Bera statistic of 35,404. As such these results generally reveal the differences across the regional sample group between developed and developing markets with extreme exhibited by the much smaller emerging markets of Indonesia and Philippines.

\section{Table 4}


(ii). Comparison of traditional CAPM, FF model and size-liquidity augmented CAPM

The results from the application of the traditional CAPM against the FF three factor model, augmented by size and book-to-market value effects, against the size and illiquidity three factor model of Martinez et al (2005) are in panels A to C in Table 5. These reveal that while both the FF and size-liquidity models exhibit improved explanatory power over the traditional CAPM the sizeliquidity model is preferable with marginally higher $\mathrm{R}^{2}$ across all nine size-illiquidity sorted portfolios than that of the FF model. Notably the absolute size of the beta coefficients on the additional two factors are larger and with higher statistical significance in the Martinez size liquidity model than in the FF model. This would indicate support for the preferential inclusion of size and liquidity factors as opposed to the size and book-to-market counterparts in the FF model. In both cases the Jensen alpha, $\alpha_{p}$, terms across the majority of the nine portfolios are not statistically significant indicating a generally good fit with theory (Markowitz, 1959) and the assumption that asset market integration holds for the stocks included within the universe. As such differentiation between the models is centred largely on relative explanatory power. Notably in the Martinez size - liquidity model the size beta coefficients are negative on big and medium size portfolios indicating a reverse size effect similar to that documented in Martinez et al (2005) for the Spanish market while coefficients are negative on low and medium illiquidity portfolios as would be expected and positive on high illiquidity portfolios indicating a potential reverse liquidity effect and poor opportunities for investors to hedge risk in using this model for highly illiquid stocks and firms.

\section{Table 5}

\section{(iii) Modelling market portfolios}

Country and industry portfolios were formed from the aggregate price-weighted averages of stock returns. The time invariant CAPM and the size-illiquidity augmented CAPM were applied to the portfolios and results reported in Table 7.

\section{Average Returns of Australian and New Zealand industries}

The evidence from Table 6 reveals that while the three-factor size liquidity augmented CAPM provides a good fit in modelling industry portfolios across both markets with Jensen alpha, $\alpha_{p}$, terms that are not statistically significant and generally large and statistically significant size and liquidity betas the explanatory power is substantially greater across Australian industry portfolios than their New Zealand counterparts. Furthermore the size beta is generally negative across Australian industries while positive across those of New Zealand indicating the presence of a documented reverse size effect in the former which is not present in the latter market. Illiquidity beta terms are generally large, negative and statistically significant across industries in both markets 
providing further indication of the good fit of the model in capturing average industry returns for blue chip stocks in both countries.

\section{Table 6}

Average Returns of Indonesia industries

The evidence regarding Indonesian industry portfolios reveals that while Jensen alpha, $\alpha_{\mathrm{p}}$, terms are not statistically significant inferring a good fit with theory (Markowitz, 1959) the size beta coefficients lack statistical significance while liquidity betas are large and statistically significant. This would indicate that liquidity is a major determinant of returns across Indonesian industry portfolios. However these results are mitigated by much lower explanatory power than in the earlier cases of Australian and New Zealand industry portfolios indicating altogether a poorer fit of the model. Explanatory power is notably higher in consumer cyclical (37.21\%) and (37.12\%) industrial sectors than other industries where apart from the aggregate Indonesian portfolio $(47.33 \%)$ it is less than $30 \%$.

Average Returns of Singapore and Malaysia industries

The evidence suggests that there are considerable differences in the determinants of average industry returns between Singapore and neighbouring Malaysia. Explanatory power is large across all industry portfolios between both countries, albeit generally in the range of $30 \%$ to $50 \%$ in Malaysia and 50\% to $70 \%$ in Singapore. However the key differences are in the smaller size and lack of statistical significance in the size and liquidity beta coefficients in Malaysian industry portfolios in direct contrast to the large and highly significant beta coefficients for both size and liquidity factors in Singapore. Furthermore liquidity betas are positive across Malaysian industries indicating a reverse liquidity effect with expected returns increasing alongside increases in aggregate illiquidity which is in direct contrast to the negative signs on Singaporean liquidity betas.

Average Returns of Thailand industries

The evidence relating to Thai industry portfolios reveals that explanatory power is generally in the range of $50 \%$ to $60 \%$ across all sectors while the Jensen alpha, $\alpha_{p}$, terms are similarly not statistically significant indicating a generally good fit of the model in application to blue chip stocks in the Thai market. However there is considerable variation in the statistical significance of the size beta coefficients while all liquidity beta coefficients are negative and statistically significant these vary dramatically in absolute size. The smallest liquidity beta is -0.035 on consumer non-cyclical while the largest is -0.771 on technology sector.

Average Returns of Hong Kong and Chinese industries 
The evidence from Table 6 reveals substantial differences between industry sectors in Hong Kong as opposed to the two Chinese markets of Shenzen and Shanghai. The first principal difference is in levels of explanatory power with these being considerably higher in both Chinese markets between $60 \%$ and $70 \%$ in contrast to a highly variable figure in Hong Kong ranging from $14.61 \%$ in basic materials to $78.88 \%$ for diversified. Jensen alpha, $\alpha_{p}$, terms in both Shanghai and Shenzen lack statistical significance across industry sectors while there is some variation in Hong Kong with the Jensen alpha terms for consumer non-cyclical and technology sector portfolios in particular being significant. The greatest difference is in the size and statistical significance of the liquidity beta coefficients. These are extremely large in absolute size and significance in both Chinese markets indicating that this is a key determinant of average industry returns while are much less statistically significant in Hong Kong and subject to greater variation. Liquidity beta coefficients in Hong Kong communications, basic materials and utilities industries are notably lacking in statistical significance while the betas themselves vary with a mix of positive and negative in contrast to the negativity of those of industries between Shanghai and Shenzen. This indicates the possibility of a reverse liquidity effect present in some Hong Kong industry sectors.

\section{Average Returns of Philippine industries}

There is generally mixed evidence regarding the performance of the three factor model in capturing the average industry returns across Philippine blue chip stocks. Both size and liquidity beta coefficients vary dramatically in absolute size and statistical significance while explanatory power is generally low. However there is considerable variation in explanatory power with this ranging from $15.84 \%$ in energy sector to $45.03 \%$ in the financial sector. Liquidity is a key determinant in the average returns of both the financial and basic materials industries as well as in the aggregate Philippine blue chip portfolio.

\section{Average Returns of South Korean industries}

The evidence suggests that there is a very good fit of the three factor model in explaining the average industry returns in South Korean blue chip stocks. Jensen alpha, $\alpha_{\mathrm{p}}$, terms are not statistically significant in any of the industry portfolios while these have generally reasonable explanatory power though this ranges from $34.10 \%$ in basic materials to $69.25 \%$ in industrial sectors. Liquidity beta coefficients are generally large, negative and statistically significant indicating that liquidity is a key determinant of average returns while size betas are negative and statistically significant indicating the presence of a reverse size effect across industries with expected returns actually decreasing as firm size or capitalization increases.

Average Returns of Japanese industries 
The evidence from Table 6 regarding Japanese industries is more mixed than in South Korea despite being very similar with large, negative and statistically significant liquidity betas and equally large, negative and statistically significant size betas. Equally similar is the lack of statistical significance in the Jensen alpha, $\alpha_{\mathrm{p}}$, terms across all industry portfolios although notably the explanatory power is dramatically reduced in contrast to South Korea ranging from $23.29 \%$ in Japanese communications to $57.11 \%$ in consumer cyclical sector.

\section{(iv) Modelling industry portfolios with time varying techniques}

The time varying coefficient model based on the augmented CAPM was only estimated with market, size and illiquidity factors. Maximum likelihood convergence was achieved in all individual national market portfolios with the sole exceptions of Australia and Indonesia with results reported in Table $7^{3}$. Generally the results are in line with those from the time-invariant time series regressions for the individual national market portfolios reported earlier in Table 6. This is also reflected in the variation between negative and positive means of the size and liquidity beta coefficients that supports those generated using time invariant methods. These results provide some support for the view that the illiquidity factor does have an important role in valuation using this methodology.

\section{Table 7}

Figures 1 to 8 provide time series plots of the evolution of the liquidity betas for the overall market portfolios for each of the individual market portfolios across the Asia-Pacific region. However while these reveal strong similarities again between both Chinese markets of Shanghai and Shenzen which again in turn are markedly different from that of Hong Kong there are substantial differences between Singapore and neighbouring Malaysia. It is notable that all reveal substantial short term variation during the very recent period of the global financial crisis and recession (2008/2009) while a distinct spike in the Thailand national market corresponding to early 2009 is more likely to be due to the initial period of political civil unrest in that country and ensuing turmoil.

\section{Figures 1 - 8}

Figures 9 to 14 provide similar time series plots for the evolution of liquidity betas for the financial sector portfolios in each of the four countries. These are markedly different from those of the overall markets. However in contrast to the individual market portfolios these support the evidence from the earlier size beta profiles where again both Chinese markets (Shanghai and Shenzen) move largely in tandem while similar evolutions are apparent between Singapore and Malaysia revealing

\footnotetext{
${ }^{3}$ Time varying Kalman filter results were also obtained across all Asia-Pacific industry portfolios although for brevity these results have not been included. These are available from author upon request.
} 
that transactions costs within the financial sectors of both countries are similar. Liquidity profiles of Indonesia reveal that there has been a net decrease in exposure to the liquidity factor for financial stocks while this has actually increased in New Zealand. The evidence that financial stocks have been effected by the global financial crisis is strongest in New Zealand with similar recent shocks in the profiles also apparent between Shanghai and Shenzen.

\section{Figures 9 - 14}

\section{(v) Asia-Pacific industry costs of equity}

Table 8 presents the contrasting estimates of cost of equity for industries across individual national markets within the wider Asia-Pacific region estimated using both the time invariant Martinez three factor size and liquidity augmented model in panel 1 and its time varying (Kalman filter) counterpart in panel 2. While both sets of estimates are generally mutually supportive there are some differences where maximum likelihood convergence was not achieved in the latter time varying model. Japanese industry blue chip stocks have the lowest costs of equity and as such are able to source finance on considerably more competitive terms than anywhere else across the AsiaPacific region which is largely intuitively expected given the dominance of the Tokyo exchange as a world market. Correspondingly costs o equity are highest and subject to greatest variation in Indonesia and Philippines although these are comparable to those across industries in both Chinese markets and Thailand where there has been considerable apathy towards the role of stock exchange finance in relation to a dominant banking sector. Following Japan Australia, New Zealand, South Korea, Singapore and Malaysia have the next lowest costs of equity across their industrial sectors indicating that these markets retain competitive character as sources of finance.

\section{Table 8}

\section{Conclusions}

This paper extends the simple mean-variance techniques proposed originally by Sharpe (1964) and Lintner (1965) in contrasting the additional strength and explanatory power arising from the inclusion of extra state variables related to firm size and book-to-market value effects cited by Fama and French (1993) alongside the size and liquidity effects documented by Martinez et al (2005). Using a unique comprehensive sample of stocks constituent to the top tier blue chip indices from major equity markets across the Asia-Pacific region, namely Australia, New Zealand, Indonesia, Singapore, Malaysia, Thailand, Philippines, Hong Kong, China Shenzen and Shanghai, South Korea and Japan I analyse individual industry portfolios and estimate comparative costs of equity.

I find evidence supporting the preferential inclusion of size and liquidity returns based factors in leading to substantial improvements in explanatory power and model fit across industry portfolios over and above the size and book-to-market value factors of Fama and French (1993). 
Furthermore I find evidence of large and substantial liquidity effects across industries within the Asia-Pacific regions equity markets underlining the importance of this effect in valuation. 


\section{REFERENCES}

Aitken, M. and Comerton-Forde, C. (2003) How should liquidity be measured? Pacific-Basin Journal of Finance, 11, 45-59.

Amihud, Y. (2002) Illiquidity and stock returns: cross section and time series effects. Journal of Financial Markets, 5, 31-56.

Amihud, Y. and Mendelson, H. (1986). Asset pricing and the bid-ask spread. Journal of Financial Economics, 17, 223-249.

ASX website (2009) ASX Australian Securities Exchange. http://www.asx.com.au/ Accessed 20 December 2009

Bekaert, G. \& Harvey, C. (1995). Time-varying world market integration. Journal of Finance, 50, 403-444.

Bertrand M, Johnson S, Samphantharak K and Schoar A (2008). Mixing family with business: A study of Thai business groups and the families behind them. Journal of Financial

Economics

$88466-498$

Bowe, M. and Domuta, D. (2004) Investor herding during financial crisis: A clinical study of the Jakarta Stock Exchange. Pacific-Basin Journal of Finance, 12, 387-418.

Brooks, R.D., Faff, R.W. \& McKenzie, M.D. (1998). Time-varying beta risk of Australian industry portfolios: A comparison of modelling techniques. Australian Journal of Management, 23(1), 1-22.

Chan, H. W. and Faff, R. W. (2003) An investigation into the role of liquidity in asset pricing: Australian evidence. Pacific-Basin Journal of Finance, 11, 555-572.

Chang, Y. Y., Faff, R. and Hwang, C-Y. (2010) Liquidity and stock returns in Japan: New evidence. Pacific-Basin Journal of Finance, 18, 90-115.

da Veiga, B., Chan, F. and McAleer, M. (2008) Evaluating the impact of market reforms on Valueat-Risk forecasts of Chinese A and B shares. Pacific-Basin Journal of Finance, 16, 453-475.

Datar, V. T., Naik, N. Y. and Radcliffe, R. (1998). Liquidity and stock returns: An alternative test. Journal of Financial Markets, 1, 203-219.

Dimson, E. (1979). Risk measurement when shares are subject to infrequent trading. Journal of Financial Economics, 7, 197-226.

Dimson, E. \& Marsh, P. (1983). The stability of UK risk measures and the problem of thin trading. Journal of Finance, 38, 753-783.

Eun, C. S. and Huang, W. (2007) Asset pricing in China's domestic stock markets: Is there a logic? Pacific-Basin Journal of Finance, 15, 452-480.

Fama, E., \& French, K. R. (1992). The cross section of expected stock returns. The Journal of Finance 47, 427-465 
Fama, E., \& French, K. (1993). Common risk factors in the returns on stocks and bonds, Journal of Financial Economics 33, 3-56

Grout, P. A. \& Zalewska, A. (2006). The impact of regulation on market risk. Journal of Financial Economics, 80, 149-184.

Hearn, B. \& Piesse, J. (2009). Sector level cost of equity in African financial markets. Emerging Market Review, 10, 257-278.

Ho R, Strange R and Piesse J (2006), On the Conditional Pricing Effects of Beta, Size, and Bookto-Market Equity in the Hong Kong Market, Journal of International Financial Markets, Institutions and Money, 16:3, 199-214

HKSE website (2009) Hong Kong Stock Exchange and Clearing Ltd. http://www.hkex.com.hk/index.htm Accessed 20 December 2009

IDX website (2009) Indonesian Stock Exchange. http://www.idx.co.id/ Accessed 20 December 2009

KLSE website (2009) Bursa Malaysia. http://www.klse.com.my/website/bm/ Accessed 20

December 2009

Lee, C. (1993). Market fragmentation and price-execution in NYSE-listed securities. Journal of Finance, 48, 1009-1038.

Lesmond, D. A. (2005) Liquidity of emerging markets. Journal of Financial Economics, 77, 411452.

Lintner, J. (1965). The valuation of risk assets and the selection of risky investments in stock portfolios and capital budgets. Review of Economics and Statistics, 17, 13-37.

Liu, W. (2006) A Liquidity-augmented capital asset pricing model. Journal of Financial Economics, $82,631-671$.

Markowitz, H. (1959) Portfolio Selection: Efficient Diversification of Investments. New York: John Wiley and Sons; London: Chapman and Hall.

Martinez, M. A., Nieto, B., Rubio, G. and Tapia, M. (2005) Asset pricing and systematic liquidity risk: An empirical investigation of the Spanish stock market. International Review of Economics and Finance, 14, 81-103.

Narayan, P. K. and Zheng, X. (2010) Market liquidity risk factor and financial market anomalies: Evidence from the Chinese stock market. Pacific-Basin Journal of Finance, 18, 509-520.

Ng, A., Yuce, A. and Chen, E. (2009) Determinants of state ownership, and its effect on value/ performance: China's privatized firms. Pacific-Basin Journal of Finance, 17, 413-443.

Newey, W. K., \& West, K. D. (1987). A simple, positive semi-definite, heteroskedasticity and autocorrelation-consistent covariance matrix, Econometrica, 55, 703-708.

NZX website (2009) NZX New Zealand Stock Exchange. http://www.nzX.com/home Accessed 20 December 2009 
O'Hara, M. (2003). Presidential address: liquidity and price discovery. Journal of Finance, 58, $1335-1354$

Pastor, L. and Stambaugh, R. (2003) Liquidity risk and expected stock returns. Journal of Political Economy, 111, 642-685.

Pettengill, G., Sundaram, S. \& Mathur, I. (1995). The conditional relation between beta and returns. Journal of Financial and Quantitative Analysis, 30, 101-116.

Pukthaunthong-Le, K. and Visaltanachoti, N. (2009) Commonality in liquidity: Evidence from the Stock Exchange of Thailand. Pacific-Basin Journal of Finance, 17, 80-99.

Scholes, M., Williams, J.T., 1977. Estimating betas from nonsynchronous data. Journal of Financial Economics 5, 309-327

SET website (2009) Stock Exchange of Thailand Research. http://www.set.or.th/setresearch/setresearch.html Accessed 20 December 2009

SGX website (2009) SGX Singapore securities exchange. http://www.sgx.com/wps/portal/marketplace/mp-en/home Accessed 20 December 2009

Sharpe, W. F. (1964). Capital asset prices: A theory of market equilibrium under conditions of risk. Journal of Finance, 19, 425-442.

Shum, W. C., and Tang, G. Y. N. (2005) Common risk factors in returns in Asian emerging stock markets. International Business Review, 14, 695-717.

SSE website (2009) Shanghai Stock Exchange. http://www.sse.com.cn/sseportal/en_us/ps/home.shtml Accessed 20 December 2009

SZSE website (2009) Shenzen Stock Exchange. http://www.szse.cn/main/en/ Accessed 20 December 2009

PSE website (2010). Philippine stock exchange. http://www.pse.com.ph/ Accessed 30 November 2009

TSE website, 2009. Tokyo Stock Exchange. http://www.tse.or.jp/english/ Accessed 22 December 2009

Watanabe, A., Watanabe, M., 2008. Time-varying Liquidity Risk and the Cross Section of Stock Returns. The Review of Financial Studies 21, 2449-2486 
Table 1 Market Capitalisation and Traded Value profiles, 2008

\begin{tabular}{|c|c|c|c|c|c|c|c|c|c|c|c|c|}
\hline & Australia & $\begin{array}{c}\text { New } \\
\text { Zealand }\end{array}$ & Indonesia & Singapore & Malaysia & Thailand & $\begin{array}{l}\text { Hong } \\
\text { Kong }\end{array}$ & $\begin{array}{c}\text { China } \\
\text { Shenzen }\end{array}$ & $\begin{array}{c}\text { China } \\
\text { Shanghai }\end{array}$ & Philippines & Japan & $\begin{array}{l}\text { South } \\
\text { Korea }\end{array}$ \\
\hline $\begin{array}{l}\text { Listed Firms/ } \\
\text { Sample size** }\end{array}$ & $2171 / 100$ & $204 / 133$ & $383 / 45$ & $762 / 177$ & $986 / 102$ & $523 / 100$ & $1241 / 201$ & $540 / 100$ & $860 / 180$ & $248 / 54$ & $1749 / 100$ & $/ 101$ \\
\hline \multicolumn{13}{|c|}{ Proportion Sector Market Capitalisation to total (\%) } \\
\hline Financials & 39.68 & 12.46 & 25.09 & 35.94 & 33.21 & 27.49 & 42.63 & 18.42 & 39.82 & 36.83 & 15.36 & 17.04 \\
\hline Comm. & 4.77 & 16.70 & 12.82 & 13.18 & 4.56 & 9.11 & 19.13 & 3.70 & 1.21 & 21.14 & 9.48 & 4.55 \\
\hline Basic Materials & 24.36 & 5.18 & 16.17 & 0.85 & 0.27 & 5.69 & 1.59 & 20.89 & 7.56 & 5.67 & 6.50 & 2.48 \\
\hline Cons cyclical & 7.32 & 11.61 & 8.92 & 9.75 & 10.10 & 8.09 & 5.48 & 10.28 & 4.08 & 12.00 & 20.34 & 3.52 \\
\hline Cons non-cyclical & 9.72 & 14.89 & 14.97 & 18.36 & 17.82 & 4.79 & 3.18 & 14.97 & 4.13 & -- -- & 8.21 & 7.65 \\
\hline Diversified & -- -- & 0.77 & -- -- & 3.51 & 12.95 & ---- & 7.80 & 3.11 & 0.27 & -- -- & -- -- & 4.60 \\
\hline Energy & 6.94 & 3.09 & 7.41 & 0.79 & 1.31 & 30.40 & 10.35 & 8.51 & 5.38 & 3.63 & 0.95 & -- -- \\
\hline Industrial & 5.94 & 23.14 & 12.93 & 16.48 & 9.39 & 11.00 & 3.50 & 16.71 & 34.55 & 16.98 & 22.46 & 32.45 \\
\hline Technology & 0.56 & 0.29 & 1.67 & 1.13 & 0.36 & 0.25 & 1.46 & 1.91 & 0.27 & -- -- & 10.43 & 27.15 \\
\hline Utilities & 0.70 & 11.87 & ---- & 0.01 & 10.02 & 3.19 & 4.88 & 1.49 & 2.73 & 3.75 & 6.26 & 0.55 \\
\hline \multicolumn{13}{|c|}{ Proportion Sector Traded Value to total (\%) } \\
\hline Financials & 35.89 & 8.76 & 16.09 & 36.65 & 34.78 & 25.16 & 37.41 & 19.29 & 35.95 & 36.52 & 28.20 & 16.95 \\
\hline Comm. & 5.79 & 35.29 & 6.05 & 9.47 & 8.04 & 7.54 & 13.84 & 3.92 & 2.35 & 18.64 & 5.50 & 3.05 \\
\hline Basic Materials & 28.32 & 1.06 & 42.31 & 1.63 & 0.07 & 6.93 & 3.89 & 22.85 & 18.04 & 9.88 & 7.30 & 1.56 \\
\hline Cons cyclical & 6.58 & 12.21 & 3.53 & 6.86 & 9.71 & 6.60 & 6.01 & 6.77 & 5.87 & 3.81 & 15.71 & 2.04 \\
\hline Cons non-cyclical & 9.57 & 6.96 & 8.93 & 15.88 & 15.59 & 3.18 & 2.59 & 13.02 & 6.41 & --- & 6.01 & 8.89 \\
\hline Diversified & -- -- & 0.59 & -- -- & 3.66 & 15.10 & -- -- & 6.31 & 5.23 & 0.88 & -- -- & -- -- & 3.44 \\
\hline Energy & 6.72 & 1.24 & 9.01 & 3.68 & 0.68 & 36.74 & 18.10 & 8.37 & 8.84 & 6.92 & 0.71 & --- \\
\hline Industrial & 6.03 & 28.64 & 13.05 & 20.93 & 6.49 & 12.50 & 5.49 & 17.14 & 17.48 & 15.41 & 23.36 & 37.57 \\
\hline Technology & 0.47 & 0.04 & 1.03 & 1.20 & 1.05 & 0.16 & 1.68 & 2.36 & 0.55 & -- -- & 9.44 & 26.06 \\
\hline Utilities & 0.63 & 5.21 & --- & 0.04 & 8.49 & 1.19 & 4.70 & 1.05 & 3.64 & 8.82 & 3.77 & 0.44 \\
\hline
\end{tabular}

Source: Compiled by authors from Bloomberg and Datastream

Notes: (1) *The value on left hand side is the total number of listed firms while that on right hand side is the number of stocks included in the sample and represents the

constituents of the top tier index in each market 
Table 2 Summary Statistics

\begin{tabular}{|c|c|c|c|c|c|c|c|c|c|}
\hline \multirow[b]{2}{*}{ Country } & \multirow[b]{2}{*}{ Sector } & \multirow[b]{2}{*}{$\begin{array}{l}\text { No. } \\
\text { Firm }\end{array}$} & \multicolumn{2}{|l|}{ Local Market } & \multirow[b]{2}{*}{ Volume ('000) } & \multirow[b]{2}{*}{ Mkt. Cap. (m) } & \multicolumn{2}{|c|}{ US\$ equivalent } & \multirow[b]{2}{*}{$\begin{array}{l}\text { Bid-Ask } \\
\text { spread }(\%)\end{array}$} \\
\hline & & & $\begin{array}{l}\text { Zero Return } \\
(\%)\end{array}$ & Price & & & Price & Mkt. Cap. (m) & \\
\hline \multirow[t]{9}{*}{ Australia } & Financials & 28 & $12.34[8.70]$ & $12.86[7.00]$ & $93088.97[66678.43]$ & $11,052.88[4,820.85]$ & $9.36[5.09]$ & $8,147.67[3,601.37]$ & $0.70[0.51]$ \\
\hline & Comm. & 4 & $10.56[8.70]$ & $5.62[4.64]$ & $220378.1[76434.53]$ & $15,214.07[1,933.43]$ & $4.13[3.19]$ & $10,345.12[1,330.73]$ & $0.89[0.69]$ \\
\hline & Basic Mat. & 17 & $13.62[9.09]$ & $8.69[3.55]$ & 86634.17 [36960.9] & $7,615.43[1,275.62]$ & $6.64[2.66]$ & $5,861.21[978.13]$ & $1.36[0.72]$ \\
\hline & Cons cyc. & 12 & $9.20[5.00]$ & $9.94[5.51]$ & $61816.19[36536.7]$ & $8,600.24[4,187.70]$ & $7.08[3.64]$ & $5,881.15[2,992.36]$ & $0.74[0.53]$ \\
\hline & Cons non-cyc. & 12 & $10.49[6.82]$ & $11.14[6.61]$ & $61388.01[48228.73]$ & $5,694.59[3,166.63]$ & $8.09[4.53]$ & $4,231.71[2,428.22]$ & $0.75[0.59]$ \\
\hline & Energy & 8 & $12.50[9.52]$ & $7.82[4.94]$ & $44890.73[31638.95]$ & $4,732.91[2,465.98]$ & $5.96[3.76]$ & $3,631.79[1,890.62]$ & $1.04[0.72]$ \\
\hline & Industrial & 15 & $11.02[8.70]$ & $6.99[5.01]$ & $74927.47[35583.55]$ & $3,015.93[2,211.71]$ & $5.26[3.66]$ & $2,238.67[1,535.41]$ & $0.91[0.65]$ \\
\hline & Technology & 1 & $8.36[8.70]$ & $6.47[6.96]$ & 38706.14 [35014.65] & $3,641.44[3,992.08]$ & $4.75[4.61]$ & $2,683.82[2,545.62]$ & $0.88[0.79]$ \\
\hline & Overall & 100 & $11.69[8.70]$ & $9.78[4.8]$ & $81621.48[44958.83]$ & $7,771.11[3,013.11]$ & $7.19[3.61]$ & $5,689.92[2,112.58]$ & $0.91[0.64]$ \\
\hline New & Financials & 33 & 63.26 [61.39] & $1.92[0.87]$ & $4204.02[929.65]$ & $235.01[90.97]$ & $1.11[0.55]$ & $145.62[56.79]$ & $10.63[2.59]$ \\
\hline \multirow{8}{*}{ Zealand } & Comm. & 8 & $51.02[41.90]$ & $2.69[2.34]$ & 37902.3 [3261.03] & $1,967.53[326.84]$ & $1.63[1.4]$ & $1,159.66$ [236.69] & $3.80[1.64]$ \\
\hline & Basic Mat. & 6 & $65.80[66.65]$ & $2.07[1.25]$ & $3340.51[1258.2]$ & $512.55[262.51]$ & $1.29[0.71]$ & $303.80[146.46]$ & $6.16[3.64]$ \\
\hline & Cons cyc. & 21 & $46.30[40.69]$ & $2.03[1.78]$ & $4183.12[721.65]$ & $428.92[104.79]$ & $1.2[1.04]$ & $254.08[64.14]$ & $4.79[1.63]$ \\
\hline & Cons non-cyc. & 34 & $58.44[57.14]$ & $2.01[1.5]$ & $2231.46[345.65]$ & $180.94[74.42]$ & $1.23[0.94]$ & $113.48[44.95]$ & $5.44[2.79]$ \\
\hline & Diversified & 2 & $29.90[30.00]$ & $2.96[2.81]$ & $1467.53[608.05]$ & $184.71[172.67]$ & $1.84[1.79]$ & 117.75 [117.03] & $1.71[1.29]$ \\
\hline & Industrial & 15 & $47.52[40.91]$ & $2.45[1.87]$ & $9262.51[1516.05]$ & $815.37[174.74]$ & $1.52[1.06]$ & $491.17[102.72]$ & $3.85[1.34]$ \\
\hline & Technology & 7 & $66.57[72.73]$ & $0.71[0.57]$ & $1786.32[530.1]$ & $31.83[22.90]$ & $0.42[0.31]$ & $19.29[13.57]$ & $13.30[4.38]$ \\
\hline & Overall & 132 & $55.46[52.17]$ & $2.08[1.22]$ & $5581.81[766.95]$ & $454.25[95.47]$ & $1.26[0.75]$ & $276.01[61.15]$ & $6.43[2.24]$ \\
\hline \multirow[t]{9}{*}{ Indonesia $\uparrow$} & Financials & 7 & $41.31[33.33]$ & $1,853.46[1,589.41]$ & $547,109.92[261,442.00]$ & $115,564.86[13,903.71]$ & $0.20[0.16]$ & $13.41[1.32]$ & $12.43[1.30]$ \\
\hline & Comm. & 2 & $23.94[21.58]$ & $3,369.76[3,704.77]$ & $1,223,221.08[688,980.4]$ & $57,971.51[65,730.99]$ & $0.36[0.39]$ & $6.18[5.85]$ & $1.03[0.73]$ \\
\hline & Basic Mat. & 7 & $32.12[28.57]$ & $1,461.01[602.63]$ & $889,495.38[467,270.05]$ & $9,396.59[1,392.33]$ & $0.15[0.06]$ & $0.98[0.15]$ & $3.43[0.69]$ \\
\hline & Cons cyc. & 1 & $17.76[17.39]$ & $10,074.16[9187.5]$ & $244,713.85[167,671.50]$ & $39,817.53[37,194.24]$ & $1.07[0.9]$ & $4.23[3.65]$ & $0.72[0.60]$ \\
\hline & Cons non-cyc. & 10 & $31.33[29.77]$ & $3,427.87[1,141.19]$ & $223,561.70[86,972.53]$ & $9,954.09[4,496.38]$ & $0.37[0.13]$ & $1.06[0.46]$ & $1.78[0.98]$ \\
\hline & Energy & 6 & $33.65[31.39]$ & $2,361.42[1,466.88]$ & $378,341.01[178,844.50]$ & $8158.90[6041.09]$ & $0.25[0.16]$ & $0.86[0.61]$ & $1.59[1.38]$ \\
\hline & Industrial & 11 & $37.84[33.33]$ & $1,379.44[631.75]$ & $623,869.45[121,889.00]$ & $5,846.46[3,413.47]$ & $0.15[0.07]$ & $0.62[0.33]$ & $4.13[1.21]$ \\
\hline & Technology & 1 & $19.75[19.05]$ & $4,084.69[4,422.29]$ & $218,381.03[192,296.75]$ & $18,258.65[23,748.49]$ & $0.44[0.47]$ & $1.93[2.45]$ & $0.70[0.69]$ \\
\hline & Overall & 45 & $34.02[30.43]$ & $2,414.94[1,109.05]$ & $548,173.00[188,614.63]$ & $28,377.73[5,508.91]$ & $0.26[0.12]$ & $3.17[0.58]$ & $4.33[1.02]$ \\
\hline \multirow[t]{7}{*}{ Thailand } & Financials & 28 & $28.76[22.61]$ & $16.30[8.91]$ & $275,739.25[87,943.30]$ & $26,904.29[9,210.49]$ & $0.43[0.23]$ & 722.77 [231.99] & $0.91[0.75]$ \\
\hline & Comm. & 10 & $29.14[21.74]$ & $16.40[7.91]$ & $1,468,024.27[118,884.05]$ & $32,965.37[8,537.83]$ & $0.43[0.19]$ & 881.93 [240.59] & $0.86[0.68]$ \\
\hline & Basic Mat. & 10 & $36.90[27.27]$ & $8.13[3.03]$ & $671,120.7[256,169.93]$ & $17,435.81[6,846.55]$ & $0.22[0.08]$ & $482.23[174.25]$ & $1.33[0.71]$ \\
\hline & Cons cyc. & 16 & $29.98[27.27]$ & $20.75[6.42]$ & $166,174.51[37,388.73]$ & $15,419.55[7,741.61]$ & $0.55[0.16]$ & $413.54[195.83]$ & $0.96[0.83]$ \\
\hline & Industrial & 14 & $24.37[22.12]$ & $39.98[17.24]$ & $134,707.09[39,151.55]$ & $27,532.70[14,608.82]$ & $1.05[0.48]$ & 738.59 [388.44] & $0.91[0.78]$ \\
\hline & Technology & 1 & $25.93[26.09]$ & $3.63[3.46]$ & $91,582.38[60,888.50]$ & $8,720.43[6,403.82]$ & $0.1[0.09]$ & $245.64[185.82]$ & $0.89[0.82]$ \\
\hline & Overall & 100 & $29.23[23.81]$ & $24.24[11.71]$ & $353,884.56[57,963.03]$ & $29,646.38[11,270.21]$ & $0.65[0.30]$ & $803.33[286.82]$ & $0.95[0.76]$ \\
\hline
\end{tabular}




\begin{tabular}{|c|c|c|c|c|c|c|c|c|c|}
\hline \multirow[b]{2}{*}{ Country } & \multirow[b]{2}{*}{ Sector } & \multirow[b]{2}{*}{$\begin{array}{l}\text { No. } \\
\text { Firm }\end{array}$} & \multicolumn{2}{|l|}{ Local Market } & \multirow[b]{2}{*}{ Volume ('000) } & \multirow[b]{2}{*}{ Mkt. Cap. (m) $\dagger$} & \multicolumn{2}{|c|}{ US\$ equivalent } & \multirow[b]{2}{*}{$\begin{array}{l}\text { Bid-Ask } \\
\text { spread (\%) }\end{array}$} \\
\hline & & & $\begin{array}{l}\text { Zero Return } \\
(\%)\end{array}$ & Price & & & Price & Mkt. Cap. (m) & \\
\hline \multirow[t]{10}{*}{ Malaysia } & Financials & 25 & $37.69[31.82]$ & $2.70[2.13]$ & $29,706.77[11,030.85]$ & $4,953.78$ [847.32] & $0.74[0.57]$ & $1,375.03[223.75]$ & $1.63[0.99]$ \\
\hline & Comm. & 4 & $29.11[28.57]$ & $4.91[3.08]$ & $71,859.58[14,611.65]$ & $4,471.88[2,709.89]$ & $1.36[0.86]$ & $1,244.47[719.43]$ & $1.06[0.91]$ \\
\hline & Basic Mat. & 3 & $36.43[34.89]$ & $1.70[1.38]$ & $3,182.05[1,171.70]$ & $633.52[663.79]$ & $0.46[0.38]$ & $174.27[178.23]$ & $2.16[1.72]$ \\
\hline & Cons cyc. & 13 & $33.64[30.43]$ & $3.36[2.94]$ & $18,230.34[5,497.85]$ & $2,585.63[1,317.10]$ & $0.92[0.79]$ & $724.50[346.25]$ & $1.54[1.03]$ \\
\hline & Cons non-cyc. & 17 & $39.60[35.68]$ & $6.87[2.66]$ & $22,029.82[2,694.50]$ & $929.43[429.30]$ & $1.89[0.70]$ & $3,318.48[1,589.17]$ & $1.30[1.04]$ \\
\hline & Diversified & 9 & $33.31[31.82]$ & $2.26[1.39]$ & $34,137.62[16,238.40]$ & $3,972.40[959.45]$ & $0.63[0.36]$ & $1,119.12[252.04]$ & $1.42[0.95]$ \\
\hline & Energy & 1 & $35.91[38.10]$ & $4.45[3.79]$ & $7,852.22[6,831.45]$ & $3,746.48[1,891.42]$ & $1.24[1.00]$ & $1,058.45[498.30]$ & $1.12[1.00]$ \\
\hline & Industrial & 20 & $42.46[35.71]$ & $3.32[2.42]$ & $17,207.88[5,564.35]$ & $2,616.59[1,017.46]$ & $0.91[0.65]$ & $723.91[272.25]$ & $1.53[1.11]$ \\
\hline & Technology & 6 & $43.92[35.36]$ & $4.11[1.75]$ & $34,127.12[10,043.80]$ & $844.37[315.10]$ & $1.10[0.49]$ & $227.18[86.84]$ & $1.92[1.11]$ \\
\hline & Overall & 102 & $37.69[31.82]$ & $3.91[2.42]$ & $25,960.94[6,983.25]$ & $3,763.95[1,153.90]$ & $1.08[0.65]$ & $1,046.70[303.60]$ & $1.5[1.02]$ \\
\hline \multirow[t]{9}{*}{ Singapore } & Financials & 38 & 30.39 [26.09] & $2.73[1.01]$ & $44,124.17[10,421.25]$ & $2,881.11$ [652.12] & $1.7[0.61]$ & $1,816.67[385.41]$ & $2.23[1.00]$ \\
\hline & Comm. & 7 & $26.06[22.12]$ & $1.78[1.55]$ & $136,498.66[79,641.03]$ & $8,920.44[1,536.72]$ & $1.1[0.96]$ & $5,532.43[945.02]$ & $1.82[0.82]$ \\
\hline & Basic Mat. & 6 & $33.93[29.99]$ & $1.46[1.21]$ & $71,596.26[4,374.00]$ & 946.50 [394.25] & $0.91[0.72]$ & 596.94 [236.67] & $4.41[1.95]$ \\
\hline & Cons cyc. & 23 & $36.51[34.78]$ & $2.11[0.45]$ & $42,824.38[8,341.98]$ & $1,679.42[227.88]$ & $1.32[0.28]$ & $1,044.55$ [145.12] & $4.03[1.89]$ \\
\hline & Cons non-cyc. & 31 & $36.67[32.97]$ & $0.78[0.39]$ & $68,910.17[13,679.75]$ & $891.30[147.60]$ & $0.49[0.24]$ & $593.11[88.10]$ & $3.95[1.53]$ \\
\hline & Diversified & 7 & $34.00[30.43]$ & $1.72[0.43]$ & $44,103.91[5,237.50]$ & $1,253.99[363.33]$ & $1.09[0.25]$ & $814.21[221.23]$ & $3.75[1.8]$ \\
\hline & Industrial & 51 & $32.76[29.06]$ & $1.31[0.67]$ & $57,052.34[13,993.95]$ & $1,023.46[337.68]$ & $0.81[0.4]$ & 647.20 [199.69] & $3.28[1.15]$ \\
\hline & Technology & 10 & $28.06[20.23]$ & $5.43[0.90]$ & $64,345.58[31,728.53]$ & $1,101.79[480.25]$ & $3.18[0.56]$ & $656.90[282.94]$ & $5.34[0.85]$ \\
\hline & Overall & 177 & $33.03[30.00]$ & $1.77[0.66]$ & $58,875.81[11,782.93]$ & $1,797.16[337.30]$ & $1.10[0.40]$ & $1,132.44[202.01]$ & $3.32[1.18]$ \\
\hline China & Financials & 52 & $16.12[9.09]$ & $8.13[5.96]$ & $336,285.01[65,472.65]$ & $35,332.60[2,321.10]$ & $1.07[0.72]$ & $4,877.65[280.45]$ & $0.23[0.16]$ \\
\hline \multirow[t]{9}{*}{ Shanghai } & Comm. & 2 & $15.32[10.00]$ & $7.21[5.15]$ & $156,686.18[112,159.75]$ & $4,700.94[1,549.43]$ & $0.95[0.63]$ & $639.70[187.22]$ & $0.22[0.17]$ \\
\hline & Basic Mat. & 24 & $14.79[9.09]$ & $9.96[5.56]$ & $505,992.91[111,184.53]$ & $17,728.77[3,702.09]$ & $1.32[0.67]$ & $2,375.82[449.25]$ & $0.21[0.17]$ \\
\hline & Cons cyc. & 17 & $15.04[8.89]$ & $8.64[5.36]$ & $210,028.68[113,808.6]$ & $10,457.86[2,931.88]$ & $1.14[0.66]$ & $1,418.24[355.03]$ & $0.21[0.17]$ \\
\hline & Cons non-cyc. & 20 & $14.93[8.89]$ & $10.04[5.82]$ & $213,815.48[82,071.7]$ & $10,271.26[3,007.31]$ & $1.33[0.71]$ & $1,394.64[365.25]$ & $0.21[0.16]$ \\
\hline & Diversified & 3 & $15.44[9.52]$ & $7.25[2.82]$ & $287,568.71[170,953.2]$ & $4,410.64[1,618.84]$ & $0.95[0.35]$ & 590.89 [197.18] & $0.18[0.16]$ \\
\hline & Energy & 14 & $15.07[8.70]$ & $10.02[6.81]$ & $240,722.21[80,150.95]$ & $11,676.99[2,970.92]$ & $1.33[0.84]$ & $1,630.25[360.41]$ & $0.19[0.14]$ \\
\hline & Industrial & 35 & $13.99[7.14]$ & $9.96[5.98]$ & $264,420.86[71,694.7]$ & $51,247.93[2,569.38]$ & $1.31[0.73]$ & $7,042.46[310.57]$ & $0.22[0.17]$ \\
\hline & Technology & 3 & $12.92[8.70]$ & $8.38[7.75]$ & $237,765.47[92,891.65]$ & $3,785.99[2,283.24]$ & $1.09[0.95]$ & 508.77 [280.49] & $0.19[0.17]$ \\
\hline & Overall & 180 & $15.16[8.70]$ & $9.02[5.67]$ & $316,155.96[80,157.60]$ & $26,795.38[2,431.97]$ & $1.19[0.69]$ & $3,674.59$ [293.64] & $0.21[0.16]$ \\
\hline \multirow[t]{7}{*}{ Philippine } & Financials & 23 & $42.62[38.10]$ & $38.78[7.68]$ & $112672.89[12920.80]$ & 28117.76 [9307.60] & $0.80[0.15]$ & $579.93[188.10]$ & $3.05[1.84]$ \\
\hline & Comm. & 5 & $30.48[28.57]$ & 540.35 [286.87] & $26428.03[2462.15]$ & $109231.06[49233.24]$ & $11.03[5.82]$ & $2290.89[944.38]$ & $1.49[1.38]$ \\
\hline & Basic Mat. & 8 & $51.08[44.24]$ & $2.21[1.13]$ & 128599.01 [26520.03] & $5665.49[1898.65]$ & $0.05[0.02]$ & $118.99[36.35]$ & $7.98[2.69]$ \\
\hline & Cons non-cyc. & 7 & $50.31[50.00]$ & 25.87 [11.17] & $28575.10[7826.10]$ & 40045.09 [18385.76] & $0.52[0.22]$ & $807.90[397.25]$ & $4.45[1.83]$ \\
\hline & Energy & 3 & $28.60[27.92]$ & 25.70 [21.99] & 31516.16 [16046.75] & $17749.85[14690.16]$ & $0.52[0.43]$ & $362.70[271.91]$ & $1.50[1.45]$ \\
\hline & Industrial & 6 & $43.32[38.10]$ & $58.48[6.90]$ & 38371.35 [7162.05] & 321629.39 [14359.37] & $1.20[0.15]$ & 6333.59 [296.63] & $2.46[1.67]$ \\
\hline & Overall & 54 & $43.89[40.24]$ & $78.26[5.23]$ & $86956.71[10410.28]$ & 68736.59 [9407.26] & $1.60[0.11]$ & 1384.34 [209.73] & $3.90[1.83]$ \\
\hline
\end{tabular}




\begin{tabular}{|c|c|c|c|c|c|c|c|c|c|}
\hline Country & Sector & $\begin{array}{l}\text { No. } \\
\text { Firm }\end{array}$ & $\begin{array}{l}\text { Local Market } \\
\text { Zero Return } \\
(\%)\end{array}$ & Price & Volume ('000) & Mkt. Cap. (m) $\dagger$ & $\begin{array}{l}\text { US\$ equivalent } \\
\text { Price }\end{array}$ & Mkt. Cap. (m) & $\begin{array}{l}\text { Bid-Ask } \\
\text { spread (\%) }\end{array}$ \\
\hline China & Financials & 13 & $16.73[9.09]$ & $7.88[4.86]$ & 332272.87 [94754.08] & $9,943.40[1,515.73]$ & $1.04[0.59]$ & $1,363.44$ [183.09] & $0.22[0.16]$ \\
\hline \multirow[t]{9}{*}{ Shenzen } & Comm. & 3 & $12.52[4.76]$ & $12.62[9.12]$ & $196777.20[116009.60]$ & $8,900.75[4,633.86]$ & $1.65[1.10]$ & $1,196.80[559.58]$ & $0.14[0.10]$ \\
\hline & Basic Mat. & 23 & $14.81[8.70]$ & $8.52[5.01]$ & 207409.17 [102465.4] & $8,617.95[3,169.72]$ & $1.13[0.61]$ & $1,158.80[383.00]$ & $0.21[0.18]$ \\
\hline & Cons cyc. & 7 & $16.62[9.52]$ & $9.70[4.41]$ & 238358.18 [133031.48] & $8,765.74[2,759.20]$ & $1.30[0.53]$ & $1,191.73[333.43]$ & $0.25[0.20]$ \\
\hline & Cons non-cyc. & 15 & $15.25[8.70]$ & $11.78[6.85]$ & $111542.03[57847.55]$ & $7,428.21[2,085.11]$ & $1.57[0.83]$ & $1,010.78$ [253.09] & $0.20[0.17]$ \\
\hline & Diversified & 6 & $17.01[11.12]$ & $5.35[3.33]$ & 281427.10 [163046.03] & $4,981.02[1,730.65]$ & $0.70[0.40]$ & 670.95 [210.99] & $0.22[0.16]$ \\
\hline & Energy & 6 & $14.59[9.31]$ & $10.51[5.15]$ & $176359.59[91349.58]$ & $6,951.90[2,749.16]$ & $1.41[0.62]$ & $957.66[336.29]$ & $0.17[0.15]$ \\
\hline & Industrial & 20 & $15.37[8.70]$ & $8.71[5.88]$ & $155632.19[84383.10]$ & $6,125.21[3,085.24]$ & $1.15[0.71]$ & 825.86 [375.19] & $0.20[0.15]$ \\
\hline & Technology & 5 & $13.74[6.85]$ & $8.58[8.54]$ & $134595.25[67071.35]$ & $7,278.08[3,531.83]$ & $1.1[1.04]$ & $935.83[426.16]$ & $0.20[0.16]$ \\
\hline & Overall & 100 & $15.37[8.70]$ & $9.10[5.43]$ & $199226.2[89684.35]$ & $7,778.58[2,426.65]$ & $1.20[0.66]$ & $1,051.19$ [293.65] & $0.21[0.17]$ \\
\hline Hong & Financials & 56 & $23.51[17.39]$ & $17.88[5.22]$ & $165,654.04[44,254.70]$ & $45,041.58[6,766.52]$ & $2.30[0.67]$ & $5,786.39$ [867.59] & $1.32[0.83]$ \\
\hline \multirow[t]{9}{*}{ Kong } & Comm. & 17 & $25.26[21.74]$ & $10.32[2.70]$ & $199,326.84[29,169.70]$ & $81,272.05[4,813.20]$ & $1.32[0.35]$ & $10,439.69$ [618.69] & $1.90[1.04]$ \\
\hline & Basic Mat. & 7 & $30.60[17.39]$ & $7.83[2.57]$ & $324,294.73[14,0155.80]$ & $12,503.30[3,329.15]$ & $1.01[0.33]$ & $1,605.81[428.23]$ & $1.34[0.75]$ \\
\hline & Cons cyc. & 29 & $24.89[19.05]$ & $7.19[2.73]$ & $159,617.51[60,732.45]$ & $23,462.75[4,268.76]$ & $0.92[0.35]$ & $3,012.09[548.25]$ & $1.54[1.00]$ \\
\hline & Cons non-cyc. & 11 & $21.09[18.61]$ & $4.93[2.81]$ & $237,823.87[83,316.45]$ & $9,555.39[4,385.45]$ & $0.63[0.36]$ & $1,228.07$ [562.29] & $1.08[1.01]$ \\
\hline & Diversified & 13 & $21.02[14.29]$ & $17.67[9.60]$ & $127,333.49[84,292.93]$ & $44,051.18[15,478.37]$ & $2.27[1.23]$ & $5,658.45[1992.27]$ & $1.00[0.63]$ \\
\hline & Energy & 7 & $16.55[13.64]$ & $3.88[3.16]$ & $\begin{array}{l}1,212,408.71 \\
{[600,025.20]}\end{array}$ & $57,090.70[8,587.68]$ & $0.50[0.41]$ & $7,338.21[1102.23]$ & $0.73[0.80]$ \\
\hline & Industrial & 25 & $28.13[16.20]$ & $7.37[2.50]$ & $198,049.47[94,538.73]$ & $8,741.33[3,244.09]$ & $0.95[0.32]$ & $1,122.98[417.37]$ & $1.09[0.87]$ \\
\hline & Technology & 25 & $28.32[22.73]$ & $5.03[1.87]$ & $91,201.52[23,265.70]$ & $6,674.97[1,305.03]$ & $0.65[0.24]$ & $857.10[167.55]$ & $1.98[1.30]$ \\
\hline & Overall & 201 & $24.84[17.39]$ & $10.92[3.12]$ & $207,518.74[58,891.05]$ & $32,006.15[4,627.94]$ & $1.40[0.40]$ & $4,111.43[594.90]$ & $1.41[0.91]$ \\
\hline \multirow[t]{8}{*}{ Japan $\dagger$} & Financials & 15 & $9.88[9.09]$ & 3054.38 [1275.69] & 272650.38 [91819.20] & $2770.96[1110.51]$ & $27.27[12.40]$ & 24741.10 [10219.45] & $0.42[0.34]$ \\
\hline & Comm. & 4 & $10.65[9.09]$ & $\begin{array}{l}221002.63 \\
{[102467.62]}\end{array}$ & 103516.39 [24143.25] & 3212.94 [1648.49] & $\begin{array}{l}1994.33 \\
{[910.23]}\end{array}$ & 29196.73 [15168.17] & $0.43[0.37]$ \\
\hline & Basic Mat. & 9 & $12.50[9.52]$ & $1754.51[522.36]$ & 266934.48 [95673.00] & $1241.05[816.21]$ & $15.77[4.89]$ & 11177.89 [7666.07] & $0.52[0.38]$ \\
\hline & Cons cyc. & 16 & $9.26[8.70]$ & 3620.95 [1554.33] & $85124.47[55252.55]$ & 2791.37 [1149.52] & $32.63[14.13]$ & 25016.76 [10776.59] & $0.36[0.32]$ \\
\hline & Cons non-cyc. & 10 & $10.12[9.09]$ & 31277.66 [2439.46] & $33867.97[34207.05]$ & 1604.18 [1083.69] & $282.46[22.53]$ & $14414.44[10225.63]$ & $0.38[0.34]$ \\
\hline & Industrial & 25 & $9.41[8.70]$ & $58589.8[2248.28]$ & 97142.17 [52749.00] & 1461.22 [1232.89] & $523.85[20.85]$ & 13177.17 [11490.57] & $0.39[0.34]$ \\
\hline & Technology & 11 & $9.16[8.70]$ & $7550.46[3347.38]$ & 84994.24 [42063.55] & 2041.88 [1589.05] & $68.08[30.49]$ & 18319.57 [14111.31] & $0.38[0.35]$ \\
\hline & Overall & 100 & $10.05[9.09]$ & 34368.86 [1930.49] & $128152.71[48241.50]$ & $2015.11[1130.10]$ & $309.76[18.54]$ & 18098.93 [10778.93] & $0.40[0.33]$ \\
\hline
\end{tabular}




\begin{tabular}{|c|c|c|c|c|c|c|c|c|c|}
\hline Country & Sector & $\begin{array}{l}\text { No. } \\
\text { Firm }\end{array}$ & $\begin{array}{l}\text { Local Market } \\
\text { Zero Return } \\
(\%)\end{array}$ & Price & Volume ('000) & Mkt. Cap. (m) & $\begin{array}{l}\text { US\$ equivalent } \\
\text { Price }\end{array}$ & Mkt. Cap. (m) & $\begin{array}{l}\text { Bid-Ask } \\
\text { spread } \\
(\%)\end{array}$ \\
\hline South & Financials & 17 & $10.46[8.70]$ & 26529.15 [10339.52] & $34354.00[23060.33]$ & $4245.20[1952.08]$ & $24.78[8.97]$ & 3997.63 [1612.94] & $0.30[0.29]$ \\
\hline \multirow[t]{7}{*}{ Korea $\uparrow$} & Comm. & 5 & $12.81[9.52]$ & 102524.01 [46211.13] & 8044.32 [4901.15] & 7896.14 [5230.23] & $92.72[41.31]$ & 7059.87 [4637.10] & $0.35[0.28]$ \\
\hline & Basic Mat. & 6 & $14.92[10.87]$ & $31072.86[24905.95]$ & 6209.51 [4817.73] & $1755.91[902.08]$ & $28.99[23.58]$ & $1648.41[863.74]$ & $0.45[0.39]$ \\
\hline & Cons non-cyc. & 18 & $11.98[9.52]$ & $113178.83[38755.74]$ & 8449.83 [1998.75] & 2077.46 [1211.17] & $105.39[31.68]$ & 1905.98 [1080.01] & $0.45[0.41]$ \\
\hline & Energy & 2 & $11.29[9.52]$ & 39170.58 [31408.18] & 31736.09 [29103.50] & 17203.49 [15530.59] & $36.22[28.92]$ & $15852.41[13520.23]$ & $0.25[0.26]$ \\
\hline & Industrial & 35 & $10.28[9.09]$ & $44604.70[15668.51]$ & $16920.74[10664.25]$ & $3265.46[1326.62]$ & $41.84[14.98]$ & $3043.90[1270.12]$ & $0.36[0.31]$ \\
\hline & Technology & 12 & $10.31[8.70]$ & $79803.77[30228.13]$ & 35234.15 [12248.85] & $12515.10[1961.81]$ & $72.69[25.41]$ & $11315.49[1632.55]$ & $0.29[0.22]$ \\
\hline & Overall & 100 & $11.17[9.09]$ & $68747.61[21966.21]$ & $19000.43[9142.80]$ & $4586.87[1290.50]$ & $63.87[21.36]$ & $4223.91[1235.73]$ & $0.37[0.32]$ \\
\hline
\end{tabular}

Source: Compiled by authors from Bloomberg, Datastream and National stock exchanges

Notes: $\quad$ indicates that units of billions are used in case of Indonesia 
Table 3. Summary statistics for equally weighted monthly excess returns on 9 size-illiquidity and size-price-to-book value portfolios for period 2001 to 2009

\begin{tabular}{|c|c|c|c|c|c|c|c|c|c|}
\hline Portfolio & $\mathbf{S} / \mathbf{L}$ & $\mathbf{S} / \mathbf{M}$ & $\mathbf{S} / \mathbf{H}$ & $\mathbf{M} / \mathbf{L}$ & $\mathbf{M} / \mathbf{M}$ & $\mathbf{M} / \mathbf{H}$ & $\mathbf{B} / \mathbf{L}$ & $\mathbf{B} / \mathbf{M}$ & $\mathbf{B} / \mathbf{H}$ \\
\hline \multicolumn{10}{|c|}{ Panel A: Portfolios sorted on Size-illiquidity } \\
\hline \multicolumn{10}{|c|}{ Summary statistics for portfolios } \\
\hline Mean & 0.0156 & 0.0167 & 0.0218 & 0.0178 & 0.0121 & 0.0207 & 0.0104 & 0.0108 & 0.0119 \\
\hline Median & 0.0250 & 0.0201 & 0.0169 & 0.0284 & 0.0128 & 0.0194 & 0.0149 & 0.0156 & 0.0176 \\
\hline Std. Dev. & 0.0858 & 0.0681 & 0.0756 & 0.0755 & 0.0650 & 0.0798 & 0.0658 & 0.0584 & 0.0659 \\
\hline Skewness & -0.02 & -0.12 & 1.50 & -0.61 & -0.86 & 0.05 & -0.72 & -0.49 & -0.81 \\
\hline Excess Kurtosis & 6.68 & 6.85 & 9.26 & 5.50 & 6.06 & 6.26 & 6.42 & 3.28 & 5.26 \\
\hline Jarque-Bera statistic & $67.55(0)$ & $74.53(0)$ & $241.04(0)$ & $38.9(0)$ & $61.66(0)$ & $53.21(0)$ & $68.75(0)$ & $5.11(0.1)$ & $38.44(0)$ \\
\hline \multicolumn{10}{|c|}{ Panel B: Average Number of stocks per size-illiquidity sorted portfolio } \\
\hline Indonesia & 1.80 & 4.13 & 2.05 & 5.38 & 3.85 & 0.73 & 7.69 & 0.70 & 0.00 \\
\hline Singapore & 22.24 & 18.08 & 34.16 & 7.10 & 6.19 & 28.71 & 2.36 & 1.20 & 19.97 \\
\hline Australia & 1.18 & 0.26 & 3.80 & 1.31 & 0.45 & 22.18 & 0.63 & 0.78 & 60.74 \\
\hline China Shanghai & 5.09 & 25.19 & 5.18 & 34.43 & 29.42 & 0.83 & 32.19 & 5.23 & 0.23 \\
\hline China Shenzen & 3.23 & 14.79 & 4.30 & 30.12 & 23.30 & 0.20 & 14.30 & 1.58 & 0.00 \\
\hline Hong Kong & 11.88 & 18.30 & 20.48 & 17.10 & 23.25 & 36.14 & 21.32 & 38.67 & 12.35 \\
\hline New Zealand & 56.46 & 14.56 & 22.07 & 5.84 & 1.95 & 12.35 & 1.67 & 0.70 & 4.50 \\
\hline Malaysia & 10.00 & 17.40 & 14.50 & 15.50 & 14.34 & 8.20 & 13.00 & 8.20 & 0.80 \\
\hline Thailand & 5.73 & 13.27 & 27.73 & 2.96 & 19.80 & 3.55 & 8.84 & 2.80 & 0.00 \\
\hline Philippines & 13.21 & 7.44 & 3.10 & 8.73 & 3.98 & 0.60 & 6.88 & 0.80 & 0.30 \\
\hline Japan & 0.03 & 0.40 & 2.03 & 0.00 & 0.90 & 0.90 & 14.75 & 50.83 & 25.90 \\
\hline South Korea & 0.00 & 0.63 & 4.40 & 1.89 & 8.55 & 27.97 & 6.71 & 24.88 & 17.88 \\
\hline Overall Mean & 130.84 & 134.44 & 143.81 & 130.35 & 135.98 & 142.35 & 130.33 & 136.34 & 142.68 \\
\hline \multicolumn{10}{|c|}{ Panel C: Valuation Factor descriptive statistics } \\
\hline & Market & FF-SMB & FF-HML & Size & Illiquidity & & & & \\
\hline Mean & 0.0152 & -0.0148 & -0.0017 & 0.0038 & 0.0003 & & & & \\
\hline Median & 0.0200 & -0.0099 & -0.0032 & 0.0019 & -0.0087 & & & & \\
\hline Std. Dev. & 0.0616 & 0.0468 & 0.0566 & 0.0375 & 0.0457 & & & & \\
\hline Skewness & -0.87 & -1.66 & 0.27 & 1.63 & 0.80 & & & & \\
\hline Excess Kurtosis & 6.50 & 9.20 & 4.34 & 9.20 & 4.06 & & & & \\
\hline Jarque-Bera statistic & $76.6(0)$ & $247.1(0)$ & $10.5(0)$ & $245.1(0)$ & $18.5(0)$ & & & & \\
\hline
\end{tabular}


Table 4. Summary statistics for individual market and sector portfolios and factors

\begin{tabular}{|c|c|c|c|c|c|c|c|c|c|c|c|c|}
\hline & Australia & $\begin{array}{l}\text { New } \\
\text { Zealand }\end{array}$ & Indonesia & Singapore & Malaysia & Thailand & Hong Kong & $\begin{array}{l}\text { China } \\
\text { Shenzen }\end{array}$ & $\begin{array}{l}\text { China } \\
\text { Shanghai }\end{array}$ & Philippines & Japan & $\begin{array}{l}\text { South } \\
\text { Korea }\end{array}$ \\
\hline \multicolumn{13}{|l|}{ Panel 1: Mean } \\
\hline Financials & 0.0107 & 0.0112 & 0.0327 & 0.0134 & 0.0053 & 0.0194 & 0.0148 & 0.0278 & 0.0191 & 0.0100 & 0.0024 & 0.0225 \\
\hline Comm. & 0.0130 & 0.0050 & 0.0275 & 0.0029 & 0.0055 & 0.0083 & 0.0164 & 0.0181 & 0.0181 & 0.0097 & -0.0044 & 0.0006 \\
\hline Basic Mat. & 0.0299 & 0.0026 & 0.0324 & 0.0138 & 0.0035 & 0.0161 & 0.0285 & 0.0214 & 0.0234 & 0.1246 & 0.0091 & 0.0168 \\
\hline Cons cyc. & 0.0127 & 0.0062 & 0.0254 & 0.0127 & 0.0044 & 0.0201 & 0.0111 & 0.0232 & 0.0212 & 0.0163 & 0.0020 & 0.0197 \\
\hline Cons non-cyc. & 0.0139 & 0.0079 & -- -- & 0.0163 & 0.0107 & 0.0351 & 0.0210 & 0.0223 & 0.0183 & -- -- & 0.0018 & 0.0152 \\
\hline Diversified & -- -- & 0.0131 & -- -- & 0.0137 & 0.0081 & -- -- & 0.0107 & 0.0224 & 0.0214 & -- -- & -- -- & -- -- \\
\hline Energy & 0.0271 & 0.0217 & 0.0226 & -- -- & 0.0170 & 0.0256 & 0.0239 & 0.0236 & 0.0273 & 0.0127 & ---- & 0.0076 \\
\hline Industrial & 0.0188 & 0.0093 & 0.0106 & 0.0148 & 0.0050 & 0.0238 & 0.0201 & 0.0220 & 0.0186 & 0.0121 & 0.0017 & 0.0277 \\
\hline Technology & 0.0110 & 0.0024 & 0.0331 & -0.0010 & 0.0019 & 0.0132 & 0.0045 & 0.0153 & 0.0107 & -- -- & -0.0040 & 0.0158 \\
\hline Utilities & 0.0123 & 0.0127 & -- -- & 0.0056 & 0.0146 & 0.0127 & 0.0102 & 0.0155 & -- -- & 0.0038 & 0.0112 & 0.0123 \\
\hline Overall & 0.0175 & 0.0081 & 0.0224 & 0.0135 & 0.0062 & 0.0202 & 0.0143 & 0.0223 & 0.0197 & 0.0337 & 0.0018 & 0.0204 \\
\hline \multicolumn{13}{|c|}{ Panel 2: Standard Deviation } \\
\hline Financials & 0.0695 & 0.0740 & 0.1659 & 0.0966 & 0.0670 & 0.1269 & 0.0841 & 0.1193 & 0.0979 & 0.0978 & 0.0878 & 0.1340 \\
\hline Comm. & 0.0843 & 0.0773 & 0.2198 & 0.0964 & 0.0736 & 0.1089 & 0.2352 & 0.1162 & 0.1054 & 0.0998 & 0.0947 & 0.0969 \\
\hline Basic Mat. & 0.0977 & 0.1007 & 0.1762 & 0.1280 & 0.0795 & 0.1115 & 0.1222 & 0.1122 & 0.1111 & 0.6939 & 0.0813 & 0.1226 \\
\hline Cons cyc. & 0.0738 & 0.0712 & 0.1393 & 0.1009 & 0.0588 & 0.0862 & 0.0817 & 0.0922 & 0.1059 & 0.1322 & 0.0578 & 0.0896 \\
\hline Cons non-cyc. & 0.0574 & 0.0600 & -- -- & 0.0934 & 0.0443 & 0.1862 & 0.0705 & 0.0936 & 0.0953 & -- -- & 0.0490 & 0.1040 \\
\hline Diversified & -- -- & 0.1009 & -- -- & 0.0960 & 0.0869 & -- -- & 0.0816 & 0.1163 & 0.1528 & -- -- & -- -- & --- \\
\hline Energy & 0.0824 & 0.0893 & 0.2104 & -- -- & 0.0618 & 0.1215 & 0.1059 & 0.1162 & 0.1408 & 0.1519 & -- -- & 0.1160 \\
\hline Industrial & 0.0847 & 0.0686 & 0.1743 & 0.0953 & 0.0579 & 0.1167 & 0.1054 & 0.0971 & 0.0962 & 0.0960 & 0.0599 & 0.1164 \\
\hline Technology & 0.1298 & 0.0986 & 0.2761 & 0.1309 & 0.1556 & 0.1240 & 0.0999 & 0.1082 & 0.1120 & -- -- & 0.0659 & 0.1254 \\
\hline Utilities & 0.0674 & 0.0686 & -- -- & 0.0536 & 0.0828 & 0.0640 & 0.1110 & 0.0996 & -- -- & 0.0497 & 0.1172 & 0.0674 \\
\hline Overall & 0.0704 & 0.0621 & 0.1310 & 0.0931 & 0.0603 & 0.1017 & 0.0805 & 0.0985 & 0.0963 & 0.1522 & 0.0566 & 0.1054 \\
\hline \multicolumn{13}{|c|}{ Panel 3: Skewness } \\
\hline Financials & -1.00 & 0.30 & 1.76 & 1.08 & -0.01 & 0.62 & 0.06 & 0.64 & 0.23 & 0.06 & 0.51 & 0.33 \\
\hline Comm. & -0.57 & 0.18 & 1.24 & -0.12 & 0.84 & -0.36 & 8.43 & -0.11 & -0.11 & 0.29 & 0.33 & 0.18 \\
\hline Basic Mat. & -0.72 & 0.58 & 0.69 & 0.29 & -0.11 & -0.14 & 1.01 & -0.03 & -0.04 & 7.04 & 0.34 & -0.40 \\
\hline Cons cyc. & -0.58 & 0.12 & -0.11 & 0.75 & 0.18 & -0.51 & -0.22 & 0.06 & 0.49 & 3.54 & 0.09 & 0.07 \\
\hline Cons non-cyc. & -0.24 & 0.00 & -- -- & 0.09 & -0.27 & 8.50 & -0.48 & 0.38 & 0.32 & -- -- & -0.37 & 0.34 \\
\hline Diversified & -- -- & -0.64 & -- -- & 1.04 & 0.23 & -- -- & 0.00 & 0.10 & 2.71 & -- -- & -- -- & -- -- \\
\hline Energy & -0.59 & -0.31 & 0.29 & --- & 0.83 & -0.05 & -0.12 & 0.33 & 1.89 & 0.71 & ---- & 0.82 \\
\hline Industrial & -0.66 & -0.10 & -0.33 & 0.41 & -0.24 & -0.05 & 1.88 & -0.09 & -0.13 & 0.20 & -0.03 & -0.09 \\
\hline Technology & 0.50 & 1.22 & 1.78 & 0.42 & 4.17 & 1.11 & 0.30 & 0.16 & 0.36 & -- -- & -0.14 & 0.49 \\
\hline Utilities & -0.63 & -0.11 & -- -- & -0.01 & -0.05 & 0.53 & 0.44 & 0.67 & --- & -0.20 & -0.15 & -0.63 \\
\hline Overall & -0.94 & -0.20 & -0.52 & 0.52 & 0.05 & -0.11 & -0.17 & -0.04 & 0.12 & 3.53 & 0.08 & 0.12 \\
\hline
\end{tabular}




\begin{tabular}{|c|c|c|c|c|c|c|c|c|c|c|c|c|}
\hline \multicolumn{13}{|c|}{ Panel 4: Excess Kurtosis } \\
\hline Financials & 7.71 & 5.62 & 12.07 & 10.25 & 3.41 & 5.78 & 4.39 & 4.34 & 3.23 & 3.54 & 3.79 & 4.26 \\
\hline Comm. & 5.86 & 3.21 & 9.15 & 5.13 & 6.68 & 3.78 & 85.44 & 4.18 & 3.47 & 3.82 & 3.59 & 3.33 \\
\hline Basic Mat. & 4.94 & 4.47 & 6.43 & 5.09 & 5.00 & 4.90 & 8.83 & 3.86 & 4.04 & 53.37 & 3.39 & 4.23 \\
\hline Cons cyc. & 5.61 & 4.91 & 5.81 & 8.89 & 3.32 & 4.60 & 4.67 & 4.29 & 5.62 & 29.45 & 2.88 & 3.32 \\
\hline Cons non-cyc. & 3.11 & 4.29 & -- -- & 4.67 & 3.55 & 86.52 & 4.37 & 4.21 & 4.39 & -- -- & 4.28 & 3.77 \\
\hline Diversified & -- -- & 8.00 & -- -- & 10.94 & 4.04 & -- -- & 4.35 & 3.91 & 19.37 & -- -- & -- -- & -- -- \\
\hline Energy & 4.34 & 4.42 & 8.32 & -- -- & 6.06 & 4.81 & 3.10 & 4.80 & 12.94 & 5.33 & -- -- & 6.84 \\
\hline Industrial & 7.95 & 4.69 & 6.35 & 7.08 & 3.22 & 3.63 & 14.51 & 3.31 & 4.12 & 4.33 & 3.01 & 3.52 \\
\hline Technology & 4.26 & 9.09 & 8.50 & 3.74 & 32.07 & 12.31 & 5.11 & 4.20 & 3.76 & -- -- & 2.75 & 3.56 \\
\hline Utilities & 4.54 & 3.40 & -- -- & 3.03 & 7.61 & 5.35 & 4.07 & 5.84 & -- -- & 3.28 & 3.51 & 4.54 \\
\hline Overall & 6.50 & 4.31 & 6.20 & 8.03 & 3.65 & 4.39 & 4.15 & 3.67 & 4.17 & 22.13 & 2.97 & 3.49 \\
\hline \multicolumn{13}{|c|}{ Panel 4: Jarque-Bera statistics } \\
\hline Financials & $7.7(0)$ & $5.6(0)$ & $12.0(0)$ & $10.2(0)$ & $3.4(0)$ & $5.7(0)$ & $4.3(0)$ & $4.3(0)$ & $3.2(0)$ & $3.5(0)$ & $3.7(0)$ & $4.2(0)$ \\
\hline Comm. & $47.4(0)$ & $0.8(0.7)$ & $219.6(0)$ & $22.9(0)$ & $81.6(0)$ & $5.7(0.1)$ & $35404.1(0)$ & $7.2(0)$ & $1.3(0.5)$ & $5.0(0.1)$ & $3.8(0.1)$ & $1.2(0.5)$ \\
\hline Basic Mat. & $29.1(0)$ & $17.5(0)$ & $68.2(0)$ & $23.5(0)$ & $20.3(0)$ & $18.4(0)$ & $189.9(0)$ & $3.7(0.2)$ & $5.4(0.1)$ & $13678.2(0)$ & $3.0(0.2)$ & $10.7(0)$ \\
\hline Cons cyc. & $40.8(0)$ & $18.4(0)$ & $39.7(0)$ & $184.5(0)$ & $1.1(0.6)$ & $17.9(0)$ & $14.9(0)$ & $8.4(0)$ & $39.3(0)$ & $3749.0(0)$ & $0.2(0.9)$ & $0.5(0.7)$ \\
\hline Cons non-cyc. & $1.2(0.5)$ & $8.3(0)$ & --- & $14.0(0)$ & $2.9(0.2)$ & $36327.3(0)$ & $14.0(0)$ & $10.1(0)$ & $11.6(0)$ & --- & $10.9(0)$ & $5.2(0.1)$ \\
\hline Diversified & -- -- & $133.0(0)$ & -- -- & $336.9(0)$ & -- -- & -- -- - - & $9.1(0)$ & $4.3(0.1)$ & $1487.3(0)$ & -- -- & -- -- & -- -- \\
\hline Energy & $15.7(0)$ & $12.0(0)$ & $143.0(0)$ & -- -- & $60.6(0)$ & $16.4(0)$ & $0.3(0.8)$ & $18.3(0)$ & $564.7(0)$ & $37.2(0)$ & -- -- & $87.1(0)$ \\
\hline Industrial & $131.2(0)$ & $14.4(0)$ & $58.1(0)$ & $86.4(0)$ & $1.3(0.5)$ & $2.0(0.4)$ & $733.4(0)$ & $0.6(0.7)$ & $6.5(0)$ & $9.6(0)$ & $0.0(1)$ & $1.5(0.5)$ \\
\hline Technology & $12.9(0)$ & $215.0(0)$ & $214.7(0)$ & $6.24(0)$ & $4573.3(0)$ & $458.2(0)$ & $24.1(0)$ & $7.7(0)$ & $5.5(0.1)$ & -- -- & $0.7(0.7)$ & $6.2(0)$ \\
\hline Utilities & $19.7(0)$ & $1.0(0.6)$ & -- -- & $0.0(1)$ & $106.4(0)$ & $33.1(0)$ & $9.5(0)$ & $49.1(0)$ & -- -- & $1.2(0.5)$ & $1.7(0.4)$ & $19.7(0)$ \\
\hline Overall & $79.1(0)$ & $9.4(0)$ & $56.8(0)$ & $131.7(0)$ & $2.2(0.3)$ & $9.9(0)$ & $7.2(0)$ & $2.3(0.3)$ & $7.2(0)$ & $2078.3(0)$ & $0.1(0.9)$ & $1.5(0.5)$ \\
\hline
\end{tabular}


Table 5 Time series regressions using equally weighted monthly contemporaneous market excess returns for 9 portfolios formed on size and illiquidity for period: $2000-2009$, for all sample markets.

\begin{tabular}{|c|c|c|c|c|c|c|c|c|c|}
\hline Portfolio & $\mathbf{S} / \mathbf{L}$ & $\mathbf{S} / \mathbf{M}$ & $\mathbf{S} / \mathbf{H}$ & $\mathbf{M} / \mathbf{L}$ & $\mathbf{M} / \mathbf{M}$ & $\mathbf{M} / \mathbf{H}$ & $\mathrm{B} / \mathrm{L}$ & $\mathbf{B} / \mathbf{M}$ & $\mathbf{B} / \mathbf{H}$ \\
\hline \multicolumn{10}{|c|}{ Panel A: CAPM-adjusted performance } \\
\hline$\hat{\alpha}(\%)$ & $-0.004(-1.35)$ & $0.001(0.46)$ & $0.010(1.96)$ & $0.004(0.14)$ & $-0.002(-0.83)$ & $0.005(1.04)$ & $-0.004(-1.29)$ & $-0.002(-0.86)$ & $-0.003(-0.74)$ \\
\hline$\hat{\beta}$ & $1.285(19.93)$ & $1.028(20.41)$ & $0.785(14.79)$ & $1.145(23.11)$ & $0.956(18.56)$ & $1.031(10.78)$ & $0.954(15.59)$ & $0.84(15.98)$ & $0.949(16.05)$ \\
\hline $\operatorname{Adj} R^{2}(1)$ & 0.8522 & 0.8654 & 0.4086 & 0.8736 & 0.8207 & 0.6322 & 0.7983 & 0.7865 & 0.7870 \\
\hline \multicolumn{10}{|c|}{ Panel B: Three-factor Fama and French model } \\
\hline$\hat{\alpha}$ & $-0.003(-1.36)$ & $-0.003(-1.36)$ & $0.001(0.39)$ & $0.006(2.97)$ & $-0.005(-2.47)$ & $-0.002(-0.62)$ & $0.002(1.02)$ & $0.005(3.09)$ & $-0.002(-0.95)$ \\
\hline$\hat{\beta}$ & $1.194(20.99)$ & $1.025(29.04)$ & $0.545(8.69)$ & $1.083(30.39)$ & $1.062(31.49)$ & $1.214(17.91)$ & $0.928(18.62)$ & $0.842(19.48)$ & $1.084(31.42)$ \\
\hline$\hat{s}$ & $-0.085(-0.63)$ & $-0.274(-3.81)$ & $-0.863(-5.73)$ & $0.271(4.9)$ & $-0.027(-0.67)$ & $-0.179(-1.62)$ & $0.376(7.21)$ & $0.468(10.37)$ & $0.213(4.44)$ \\
\hline$\hat{h}$ & $0.244(3.61)$ & $-0.16(-2.81)$ & $0.238(2.76)$ & $0.373(8.33)$ & $-0.362(-7.31)$ & $-0.708(-7.01)$ & $0.319(5.16)$ & $0.289(6.53)$ & $-0.307(-4.52)$ \\
\hline $\operatorname{Adj} R^{2}(4)$ & 0.8836 & 0.8923 & 0.7872 & 0.9281 & 0.9036 & 0.8197 & 0.8677 & 0.8956 & 0.9053 \\
\hline \multicolumn{10}{|c|}{ Panel C: Three-factor Size and Illiquidity CAPM performance } \\
\hline$\hat{\alpha}$ & $-0.003(-2.00)$ & $0.003(0.17)$ & 0.007 (2.12) & $0.002(1.73)$ & $-0.003(-1.25)$ & 0.003 (1.22) & $-0.002(-1.02)$ & $-0.005(-0.28)$ & $-0.003(-1.67)$ \\
\hline$\hat{\beta}$ & $1.119(39.46)$ & $0.996(32.23)$ & $0.713(12.61)$ & $1.056(49.08)$ & $1.038(21.20)$ & $1.252(21.45)$ & $0.889(23.94)$ & $0.842(15.80)$ & $1.098(45.14)$ \\
\hline$\hat{s}$ & $0.424(5.11)$ & $0.33(2.94)$ & $1.088(4.40)$ & $-0.059(-0.77)$ & $-0.245(-3.55)$ & $-0.330(-2.58)$ & $-0.200(-2.29)$ & $-0.373(-6.35)$ & $-0.588(-8.33)$ \\
\hline$\hat{h}$ & $-0.563(-9.12)$ & $0.037(0.57)$ & $0.282(2.01)$ & $-0.467(-11.23)$ & $0.257(4.12)$ & $0.884(8.02)$ & $-0.433(-6.76)$ & $-0.210(-4.95)$ & $0.385(6.39)$ \\
\hline $\operatorname{Adj} R^{2}(4)$ & 0.9580 & 0.8986 & 0.7326 & 0.9495 & 0.8654 & 0.8770 & 0.9006 & 0.8740 & 0.9440 \\
\hline
\end{tabular}

Notes: (1) Numbers in parentheses are t-statistics.

(2) 10 year US Treasury yield taken as risk free rate 
Table 6 Time series regressions for equally weighted monthly excess returns on country portfolios with size and illiquidity for 2002 to 2009

\begin{tabular}{|c|c|c|c|c|c|c|c|c|c|c|c|}
\hline & Financials & Comm. & $\begin{array}{c}\text { Basic } \\
\text { Materials }\end{array}$ & $\begin{array}{c}\text { Cons } \\
\text { cyclical }\end{array}$ & $\begin{array}{c}\text { Cons non- } \\
\text { cyclical }\end{array}$ & Diversified & Energy & Industrial & Tech & Utilities & Overall \\
\hline $\begin{array}{l}\text { Australia } \\
\hat{\alpha}\end{array}$ & $\begin{array}{l}-0.001 \\
(-0.26)\end{array}$ & $\begin{array}{l}-0.001 \\
(-0.25)\end{array}$ & $\begin{array}{l}0.014 \\
(2.54)\end{array}$ & $\begin{array}{l}0.001 \\
(0.03)\end{array}$ & $\begin{array}{l}0.005 \\
(1.40)\end{array}$ & -- -- & $\begin{array}{l}0.016 \\
(2.66)\end{array}$ & $\begin{array}{l}0.005 \\
(0.97)\end{array}$ & $\begin{array}{l}-0.001 \\
(-0.12)\end{array}$ & $\begin{array}{l}0.004 \\
(0.73)\end{array}$ & $\begin{array}{l}0.005 \\
(1.34)\end{array}$ \\
\hline$\hat{\beta}$ & $\begin{array}{c}0.821 \\
(14.31)\end{array}$ & $\begin{array}{c}0.999 \\
(15.17)\end{array}$ & $\begin{array}{c}1.129 \\
(12.97)\end{array}$ & $\begin{array}{c}0.879 \\
(17.36)\end{array}$ & $\begin{array}{c}0.599 \\
(10.80)\end{array}$ & -- -- & $\begin{array}{c}0.800 \\
(11.66)\end{array}$ & $\begin{array}{c}0.955 \\
(11.07)\end{array}$ & $\begin{array}{l}0.933 \\
(5.41)\end{array}$ & $\begin{array}{l}0.563 \\
(8.58)\end{array}$ & $\begin{array}{c}0.880 \\
(19.99)\end{array}$ \\
\hline$\hat{s}$ & $\begin{array}{l}-0.161 \\
(-1.10)\end{array}$ & $\begin{array}{l}-0.183 \\
(-0.80)\end{array}$ & $\begin{array}{l}-0.134 \\
(-0.94)\end{array}$ & $\begin{array}{l}-0.168 \\
(-0.98)\end{array}$ & $\begin{array}{l}-0.140 \\
(-0.99)\end{array}$ & -- -- & $\begin{array}{l}-0.098 \\
(-0.84)\end{array}$ & $\begin{array}{l}-0.110 \\
(-0.65)\end{array}$ & $\begin{array}{l}-0.454 \\
(-1.63)\end{array}$ & $\begin{array}{l}0.034 \\
(0.17)\end{array}$ & $\begin{array}{l}-0.142 \\
(-1.11)\end{array}$ \\
\hline$\hat{h}$ & $\begin{array}{l}-0.366 \\
(-4.21)\end{array}$ & $\begin{array}{l}-0.320 \\
(-2.24)\end{array}$ & $\begin{array}{l}-0.589 \\
(-4.61)\end{array}$ & $\begin{array}{l}-0.377 \\
(-3.57)\end{array}$ & $\begin{array}{l}-0.297 \\
(-2.92)\end{array}$ & -- -- & $\begin{array}{l}-0.561 \\
(-4.49)\end{array}$ & $\begin{array}{l}-0.549 \\
(-4.46)\end{array}$ & $\begin{array}{l}-0.381 \\
(-1.31)\end{array}$ & $\begin{array}{l}-0.230 \\
(-2.10)\end{array}$ & $\begin{array}{l}-0.436 \\
(-5.16)\end{array}$ \\
\hline $\operatorname{Adj} R^{2}$ & 0.6695 & 0.6170 & 0.6804 & 0.6708 & 0.5422 & -- -- & 0.5502 & 0.6742 & 0.2425 & 0.3378 & 0.7788 \\
\hline New Zealand & & & & & & & & & & & \\
\hline$\hat{\alpha}$ & $\begin{array}{l}0.001 \\
(0.27)\end{array}$ & $\begin{array}{l}-0.004 \\
(-0.62)\end{array}$ & $\begin{array}{l}-0.010 \\
(-1.34)\end{array}$ & $\begin{array}{l}-0.006 \\
(-1.22)\end{array}$ & $\begin{array}{l}-0.001 \\
(-0.40)\end{array}$ & $\begin{array}{l}0.003 \\
(0.28)\end{array}$ & $\begin{array}{l}0.012 \\
(1.52)\end{array}$ & $\begin{array}{l}-0.004 \\
(-0.09)\end{array}$ & $\begin{array}{l}-0.008 \\
(-1.33)\end{array}$ & $\begin{array}{l}0.004 \\
(0.88)\end{array}$ & $\begin{array}{l}-0.002 \\
(-0.51)\end{array}$ \\
\hline$\hat{\beta}$ & $\begin{array}{l}0.580 \\
(7.90)\end{array}$ & $\begin{array}{l}0.583 \\
(7.36)\end{array}$ & $\begin{array}{l}0.754 \\
(7.85)\end{array}$ & $\begin{array}{c}0.726 \\
(10.68)\end{array}$ & $\begin{array}{c}0.544 \\
(10.82)\end{array}$ & $\begin{array}{l}0.561 \\
(3.37)\end{array}$ & $\begin{array}{l}0.587 \\
(7.83)\end{array}$ & $\begin{array}{l}0.578 \\
(7.71)\end{array}$ & $\begin{array}{l}0.793 \\
(5.14)\end{array}$ & $\begin{array}{l}0.539 \\
(7.77)\end{array}$ & $\begin{array}{c}0.613 \\
(12.62)\end{array}$ \\
\hline$\hat{s}$ & $\begin{array}{l}0.258 \\
(1.78)\end{array}$ & $\begin{array}{l}0.087 \\
(0.48)\end{array}$ & $\begin{array}{l}0.342 \\
(2.36)\end{array}$ & $\begin{array}{l}0.218 \\
(1.87)\end{array}$ & $\begin{array}{l}0.291 \\
(3.12)\end{array}$ & $\begin{array}{l}0.574 \\
(4.34)\end{array}$ & $\begin{array}{l}0.322 \\
(1.66)\end{array}$ & $\begin{array}{l}0.278 \\
(2.14)\end{array}$ & $\begin{array}{l}-0.363 \\
(-1.20)\end{array}$ & $\begin{array}{l}0.165 \\
(1.35)\end{array}$ & $\begin{array}{l}0.226 \\
(2.16)\end{array}$ \\
\hline$\hat{h}$ & $\begin{array}{l}-0.258 \\
(-1.99)\end{array}$ & $\begin{array}{l}-0.331 \\
(-2.72)\end{array}$ & $\begin{array}{l}-0.680 \\
(-3.68)\end{array}$ & $\begin{array}{l}-0.297 \\
(-2.76)\end{array}$ & $\begin{array}{l}-0.366 \\
(-4.44)\end{array}$ & $\begin{array}{l}-0.743 \\
(-4.36)\end{array}$ & $\begin{array}{l}-0.361 \\
(-2.38)\end{array}$ & $\begin{array}{l}-0.436 \\
(-3.62)\end{array}$ & $\begin{array}{l}-0.255 \\
(-1.23)\end{array}$ & $\begin{array}{l}-0.512 \\
(-4.09)\end{array}$ & $\begin{array}{l}-0.352 \\
(-3.58)\end{array}$ \\
\hline $\operatorname{Adj} \mathrm{R}^{2}$ & 0.3409 & 0.3135 & 0.4233 & 0.5374 & 0.5448 & 0.3634 & 0.2777 & 0.4877 & 0.2853 & 0.4650 & 0.5725 \\
\hline Indonesia & & & & & & & & & & & \\
\hline$\hat{\alpha}$ & $\begin{array}{l}0.018 \\
(1.42)\end{array}$ & $\begin{array}{l}0.013 \\
(0.96)\end{array}$ & $\begin{array}{l}0.011 \\
(0.80)\end{array}$ & $\begin{array}{l}0.006 \\
(0.51)\end{array}$ & -- -- & --- & $\begin{array}{l}0.004 \\
(0.20)\end{array}$ & $\begin{array}{l}-0.014 \\
(-0.96)\end{array}$ & $\begin{array}{l}0.021 \\
(1.30)\end{array}$ & -- -- & $\begin{array}{l}0.002 \\
(0.19)\end{array}$ \\
\hline$\hat{\beta}$ & $\begin{array}{l}0.889 \\
(3.16)\end{array}$ & $\begin{array}{l}1.156 \\
(4.55)\end{array}$ & $\begin{array}{l}1.280 \\
(6.17)\end{array}$ & $\begin{array}{l}1.231 \\
(6.27)\end{array}$ & -- -- & -- -- & $\begin{array}{l}1.038 \\
(2.84)\end{array}$ & $\begin{array}{l}1.657 \\
(6.11)\end{array}$ & $\begin{array}{l}0.856 \\
(2.61)\end{array}$ & -- -- & $\begin{array}{l}1.305 \\
(7.24)\end{array}$ \\
\hline$\hat{s}$ & $\begin{array}{l}0.210 \\
(0.48)\end{array}$ & $\begin{array}{l}-0.790 \\
(-1.67)\end{array}$ & $\begin{array}{l}0.498 \\
(1.20)\end{array}$ & $\begin{array}{l}0.321 \\
(1.26)\end{array}$ & ---- & ---- & $\begin{array}{l}0.694 \\
(1.19)\end{array}$ & $\begin{array}{l}-0.092 \\
(-0.25)\end{array}$ & $\begin{array}{l}-0.102 \\
(-0.14)\end{array}$ & ---- & $\begin{array}{l}0.257 \\
(0.95)\end{array}$ \\
\hline$\hat{h}$ & $\begin{array}{l}-0.244 \\
(-1.07) \\
\end{array}$ & $\begin{array}{l}-0.603 \\
(-2.11) \\
\end{array}$ & $\begin{array}{l}-0.447 \\
(-1.06) \\
\end{array}$ & $\begin{array}{l}-0.365 \\
(-1.83) \\
\end{array}$ & -- -- & -- -- & $\begin{array}{l}-0.658 \\
(-2.01) \\
\end{array}$ & $\begin{array}{l}-0.306 \\
(-1.28) \\
\end{array}$ & $\begin{array}{l}-0.591 \\
(-1.40) \\
\end{array}$ & -- -- & $\begin{array}{l}-0.434 \\
(-2.02) \\
\end{array}$ \\
\hline $\operatorname{Adj} R^{2}$ & 0.1340 & 0.1455 & 0.2711 & 0.3721 & -- -- & $\begin{array}{ll}---- \\
\end{array}$ & 0.1656 & 0.3712 & 0.0556 & -- -- & 0.4733 \\
\hline
\end{tabular}




\begin{tabular}{|c|c|c|c|c|c|c|c|c|c|c|c|}
\hline & Financials & Comm. & $\begin{array}{c}\text { Basic } \\
\text { Materials }\end{array}$ & $\begin{array}{c}\text { Cons } \\
\text { cyclical }\end{array}$ & $\begin{array}{c}\text { Cons non- } \\
\text { cyclical }\end{array}$ & Diversified & Energy & Industrial & Tech & Utilities & Overall \\
\hline \multicolumn{12}{|l|}{ Malaysia } \\
\hline$\hat{\alpha}$ & $\begin{array}{l}-0.007 \\
(-1.54)\end{array}$ & $\begin{array}{l}-0.003 \\
(-0.48)\end{array}$ & $\begin{array}{l}-0.008 \\
(-1.18)\end{array}$ & $\begin{array}{l}-0.005 \\
(-1.46)\end{array}$ & $\begin{array}{l}0.003 \\
(0.96)\end{array}$ & $\begin{array}{l}-0.008 \\
(-1.81)\end{array}$ & $\begin{array}{l}0.010 \\
(1.98)\end{array}$ & $\begin{array}{l}-0.005 \\
(-1.18)\end{array}$ & $\begin{array}{l}-0.015 \\
(-1.33)\end{array}$ & $\begin{array}{l}-0.002 \\
(-0.68)\end{array}$ & $\begin{array}{l}-0.005 \\
(-1.21)\end{array}$ \\
\hline \multirow[t]{2}{*}{$\hat{\beta}$} & 0.735 & 0.563 & 0.702 & 0.615 & 0.468 & 1.006 & 0.520 & 0.603 & 1.007 & 0.509 & 0.671 \\
\hline & $(9.59)$ & $(5.43)$ & (6.63) & $(9.62)$ & $(8.55)$ & (13.28) & $(5.61)$ & $(9.90)$ & $(3.68)$ & $(7.83)$ & (10.46) \\
\hline \multirow[t]{2}{*}{$\hat{s}$} & 0.176 & -0.076 & 0.105 & 0.126 & 0.100 & 0.281 & -0.180 & 0.093 & 0.363 & 0.082 & 0.142 \\
\hline & (1.11) & $(-0.27)$ & $(0.58)$ & $(0.82)$ & $(1.00)$ & $(1.86)$ & $(-1.17)$ & $(0.67)$ & $(0.87)$ & $(0.57)$ & $(0.95)$ \\
\hline \multirow{2}{*}{$\hat{h}$} & 0.092 & 0.232 & -0.119 & 0.024 & 0.076 & 0.161 & 0.168 & 0.067 & 0.282 & 0.068 & 0.092 \\
\hline & $(0.78)$ & $(1.09)$ & $(-0.75)$ & $(0.23)$ & $(1.15)$ & $(1.57)$ & $(1.67)$ & $(0.78)$ & $(0.75)$ & $(0.66)$ & $(0.93)$ \\
\hline Adj $R^{2}$ & 0.4744 & 0.1991 & 0.3344 & 0.4352 & 0.4310 & 0.5323 & 0.2372 & 0.4157 & 0.1696 & 0.3437 & 0.4793 \\
\hline \multicolumn{12}{|l|}{ Thailand } \\
\hline$\hat{\alpha}$ & $\begin{array}{l}0.004 \\
(0.05)\end{array}$ & $\begin{array}{l}-0.007 \\
(-0.85)\end{array}$ & $\begin{array}{c}0.000 \\
(-0.03)\end{array}$ & $\begin{array}{l}0.008 \\
(1.39)\end{array}$ & $\begin{array}{l}0.019 \\
(1.92)\end{array}$ & -- -- & $\begin{array}{l}0.006 \\
(0.77)\end{array}$ & $\begin{array}{l}0.005 \\
(0.55)\end{array}$ & $\begin{array}{l}-0.004 \\
(-0.53)\end{array}$ & $\begin{array}{l}0.005 \\
(1.09)\end{array}$ & $\begin{array}{l}0.003 \\
(0.56)\end{array}$ \\
\hline$\hat{\beta}$ & $\begin{array}{l}1.181 \\
(945)\end{array}$ & $\begin{array}{l}1.059 \\
(7.40)\end{array}$ & 0.964 & $\begin{array}{l}0.781 \\
(974)\end{array}$ & 0.933 & -- -- & 1.226 & $\begin{array}{l}1.193 \\
(958)\end{array}$ & $\begin{array}{l}1.087 \\
(8.45)\end{array}$ & 0.595 & 1.048 \\
\hline \multirow[t]{2}{*}{$\hat{S}$} & 0.335 & -0.048 & 0.496 & 0.232 & 0.566 & ---- & 0.399 & 0.352 & 0.230 & 0.226 & 0.306 \\
\hline & (1.79) & $(-0.27)$ & $(2.41)$ & $(1.32)$ & (1.43) & & $(2.23)$ & (1.91) & (1.01) & $(1.25)$ & (1.91) \\
\hline \multirow{2}{*}{$\hat{h}$} & -0.685 & -0.478 & -0.693 & -0.579 & -0.035 & -- -- & -0.416 & -0.552 & -0.771 & -0.231 & -0.544 \\
\hline & $(-4.65)$ & $(-3.43)$ & $(-5.52)$ & $(-4.89)$ & $(-0.09)$ & & $(-3.03)$ & $(-3.78)$ & $(-3.07)$ & $(-2.13)$ & $(-4.68)$ \\
\hline $\operatorname{Adj} R^{2}$ & 0.4977 & 0.4623 & 0.5071 & 0.5308 & 0.1237 & -- -- & 0.5089 & 0.5576 & 0.4754 & 0.2710 & 0.5879 \\
\hline \multicolumn{12}{|l|}{ Hong Kong } \\
\hline$\hat{\alpha}$ & $\begin{array}{l}-0.001 \\
(-0.36)\end{array}$ & $\begin{array}{l}-0.003 \\
(-0.16)\end{array}$ & $\begin{array}{l}0.008 \\
(1.05)\end{array}$ & $\begin{array}{l}-0.004 \\
(-1.09)\end{array}$ & $\begin{array}{l}0.008 \\
(2.25)\end{array}$ & $\begin{array}{l}-0.005 \\
(-1.23)\end{array}$ & $\begin{array}{l}0.008 \\
(1.22)\end{array}$ & $\begin{array}{l}0.003 \\
(0.45)\end{array}$ & $\begin{array}{l}-0.015 \\
(-3.12)\end{array}$ & $\begin{array}{l}0.003 \\
(0.80)\end{array}$ & $\begin{array}{l}-0.002 \\
(-0.64)\end{array}$ \\
\hline \multirow{2}{*}{$\hat{\beta}$} & 1.060 & 1.471 & 1.442 & 1.031 & 0.845 & 1.048 & 1.085 & 1.131 & 1.288 & 0.723 & 1.110 \\
\hline & $(17.72)$ & $(2.93)$ & $(7.81)$ & $(16.58)$ & $(15.80)$ & (13.63) & $(7.93)$ & (18.23) & (14.87) & $(10.62)$ & $(17.45)$ \\
\hline \multirow[t]{2}{*}{$\hat{s}$} & 0.067 & -0.972 & -0.301 & -0.037 & 0.016 & -0.077 & -0.111 & 0.051 & 0.009 & -0.318 & -0.098 \\
\hline & $(0.55)$ & $(-1.10)$ & $(-1.28)$ & $(-0.46)$ & $(0.17)$ & $(-0.60)$ & $(-0.48)$ & $(0.22)$ & $(0.04)$ & $(-2.72)$ & $(-0.75)$ \\
\hline \multirow{2}{*}{$\hat{h}$} & -0.438 & 1.090 & -0.141 & -0.333 & -0.254 & -0.429 & -0.379 & -0.324 & -0.354 & -0.044 & -0.235 \\
\hline & $(-4.68)$ & $(0.81)$ & $(-0.95)$ & $(-4.13)$ & $(-3.85)$ & $(-6.15)$ & $(-2.80)$ & $(-2.04)$ & $(-3.07)$ & $(-0.30)$ & $(-1.77)$ \\
\hline Adj $R^{2}$ & 0.7709 & 0.1461 & 0.5355 & 0.7149 & 0.6425 & 0.7788 & 0.4741 & 0.5131 & 0.7294 & 0.4814 & 0.7888 \\
\hline
\end{tabular}




\begin{tabular}{|c|c|c|c|c|c|c|c|c|c|c|c|}
\hline & Financials & Comm. & $\begin{array}{c}\text { Basic } \\
\text { Materials }\end{array}$ & $\begin{array}{c}\text { Cons } \\
\text { cyclical }\end{array}$ & $\begin{array}{l}\text { Cons non- } \\
\text { cyclical }\end{array}$ & Diversified & Energy & Industrial & Tech & Utilities & $\overline{\text { Overall }}$ \\
\hline \multicolumn{12}{|l|}{ China Shenzen } \\
\hline$\hat{\alpha}$ & $\begin{array}{l}0.010 \\
(1.49)\end{array}$ & $\begin{array}{l}-0.004 \\
(-0.07)\end{array}$ & $\begin{array}{l}0.001 \\
(0.19)\end{array}$ & $\begin{array}{l}0.008 \\
(1.52)\end{array}$ & $\begin{array}{l}0.007 \\
(1.51)\end{array}$ & $\begin{array}{l}0.004 \\
(0.48)\end{array}$ & $\begin{array}{l}0.003 \\
(0.42)\end{array}$ & $\begin{array}{l}0.005 \\
(0.98)\end{array}$ & $\begin{array}{l}-0.003 \\
(-0.49)\end{array}$ & $\begin{array}{l}-0.005 \\
(-0.74)\end{array}$ & $\begin{array}{l}0.004 \\
(0.94)\end{array}$ \\
\hline$\hat{\beta}$ & $\begin{array}{c}1.370 \\
(10.86)\end{array}$ & $\begin{array}{l}1.327 \\
(8.33)\end{array}$ & $\begin{array}{c}1.471 \\
(14.77)\end{array}$ & $\begin{array}{c}1.123 \\
(10.99)\end{array}$ & $\begin{array}{l}1.109 \\
(12.2)\end{array}$ & $\begin{array}{l}1.313 \\
(9.49)\end{array}$ & $\begin{array}{l}1.494 \\
(9.99)\end{array}$ & $\begin{array}{c}1.160 \\
(13.30)\end{array}$ & $\begin{array}{c}1.240 \\
(10.76)\end{array}$ & $\begin{array}{l}1.064 \\
(7.5)\end{array}$ & $\begin{array}{c}1.286 \\
(15.05)\end{array}$ \\
\hline$\hat{s}$ & $\begin{array}{l}-0.793 \\
(-2.87)\end{array}$ & $\begin{array}{l}-0.526 \\
(-2.75)\end{array}$ & $\begin{array}{l}-0.633 \\
(-4.44)\end{array}$ & $\begin{array}{l}-0.454 \\
(-4.02)\end{array}$ & $\begin{array}{l}-0.419 \\
(-3.40)\end{array}$ & $\begin{array}{l}-0.475 \\
(-2.41)\end{array}$ & $\begin{array}{l}-0.647 \\
(-3.85)\end{array}$ & $\begin{array}{l}-0.368 \\
(-2.78)\end{array}$ & $\begin{array}{l}-0.242 \\
(-1.57)\end{array}$ & $\begin{array}{l}-0.254 \\
(-1.32)\end{array}$ & $\begin{array}{l}-0.518 \\
(-4.37)\end{array}$ \\
\hline$\hat{h}$ & $\begin{array}{l}1.593 \\
(7.12)\end{array}$ & $\begin{array}{l}1.254 \\
(7.52)\end{array}$ & $\begin{array}{c}1.486 \\
(12.60)\end{array}$ & $\begin{array}{l}1.157 \\
(7.58)\end{array}$ & $\begin{array}{l}1.210 \\
(9.06)\end{array}$ & $\begin{array}{l}1.401 \\
(8.17)\end{array}$ & $\begin{array}{l}1.226 \\
(6.28)\end{array}$ & $\begin{array}{l}1.315 \\
(9.18)\end{array}$ & $\begin{array}{l}1.386 \\
(9.87)\end{array}$ & $\begin{array}{l}1.197 \\
(5.81)\end{array}$ & $\begin{array}{c}1.367 \\
(11.73)\end{array}$ \\
\hline $\operatorname{Adj} R^{2}$ & 0.6149 & 0.5210 & 0.7151 & 0.6245 & 0.6146 & 0.5497 & 0.6188 & 0.6450 & 0.5918 & 0.4147 & 0.7326 \\
\hline \multicolumn{12}{|l|}{ China Shanghai } \\
\hline$\hat{\alpha}$ & $\begin{array}{l}0.002 \\
(0.44)\end{array}$ & $\begin{array}{l}0.002 \\
(0.30)\end{array}$ & $\begin{array}{l}0.004 \\
(0.68)\end{array}$ & $\begin{array}{l}0.002 \\
(0.44)\end{array}$ & $\begin{array}{l}0.003 \\
(0.68)\end{array}$ & $\begin{array}{l}-0.001 \\
(-0.14)\end{array}$ & $\begin{array}{l}0.007 \\
(0.87)\end{array}$ & $\begin{array}{l}0.001 \\
(0.27)\end{array}$ & $\begin{array}{l}-0.005 \\
(-0.80)\end{array}$ & $\begin{array}{l}-0.001 \\
(-0.16)\end{array}$ & $\begin{array}{l}0.002 \\
(0.49)\end{array}$ \\
\hline$\hat{\beta}$ & $\begin{array}{c}1.191 \\
(10.99)\end{array}$ & $\begin{array}{l}1.126 \\
(8.37)\end{array}$ & $\begin{array}{c}1.406 \\
(12.92)\end{array}$ & $\begin{array}{c}1.296 \\
(11.05)\end{array}$ & $\begin{array}{c}1.117 \\
(11.93)\end{array}$ & $\begin{array}{l}1.591 \\
(6.15)\end{array}$ & $\begin{array}{l}1.558 \\
(8.05)\end{array}$ & $\begin{array}{c}1.224 \\
(13.76)\end{array}$ & $\begin{array}{l}1.103 \\
(6.36)\end{array}$ & $\begin{array}{l}1.126 \\
(9.85)\end{array}$ & $\begin{array}{c}1.245 \\
(13.15)\end{array}$ \\
\hline$\hat{s}$ & $\begin{array}{l}-0.483 \\
(-4.07)\end{array}$ & $\begin{array}{l}-0.429 \\
(-2.54)\end{array}$ & $\begin{array}{l}-0.559 \\
(-4.27)\end{array}$ & $\begin{array}{l}-0.332 \\
(-2.12)\end{array}$ & $\begin{array}{l}-0.500 \\
(-4.13)\end{array}$ & $\begin{array}{l}-0.633 \\
(-2.43)\end{array}$ & $\begin{array}{l}-0.901 \\
(-2.62)\end{array}$ & $\begin{array}{l}-0.459 \\
(-3.99)\end{array}$ & $\begin{array}{l}-0.277 \\
(-1.27)\end{array}$ & $\begin{array}{l}-0.328 \\
(-2.28)\end{array}$ & $\begin{array}{l}-0.468 \\
(-4.43)\end{array}$ \\
\hline$\hat{h}$ & $\begin{array}{c}1.300 \\
(10.74)\end{array}$ & $\begin{array}{l}1.054 \\
(5.20)\end{array}$ & $\begin{array}{c}1.554 \\
(11.95)\end{array}$ & $\begin{array}{l}1.458 \\
(8.32)\end{array}$ & $\begin{array}{l}1.367 \\
(8.63)\end{array}$ & $\begin{array}{l}2.042 \\
(5.08)\end{array}$ & $\begin{array}{l}1.411 \\
(3.5)\end{array}$ & $\begin{array}{l}1.250 \\
(8.82)\end{array}$ & $\begin{array}{l}1.123 \\
(6.18)\end{array}$ & $\begin{array}{l}1.382 \\
(8.31)\end{array}$ & $\begin{array}{l}1.353 \\
(11.2)\end{array}$ \\
\hline $\operatorname{Adj} R^{2}$ & 0.6497 & 0.4539 & 0.7092 & 0.6735 & 0.6614 & 0.5442 & 0.4864 & 0.6780 & 0.4073 & 0.6173 & 0.7296 \\
\hline \multicolumn{12}{|l|}{ Singapore } \\
\hline$\hat{\alpha}$ & $\begin{array}{l}-0.005 \\
(-1.02)\end{array}$ & $\begin{array}{l}-0.013 \\
(-1.93)\end{array}$ & $\begin{array}{l}-0.008 \\
(-1.33)\end{array}$ & $\begin{array}{l}-0.007 \\
(-1.89)\end{array}$ & $\begin{array}{l}-0.001 \\
(-0.26)\end{array}$ & $\begin{array}{l}-0.003 \\
(-0.60)\end{array}$ & -- -- & $\begin{array}{l}-0.004 \\
(-1.12)\end{array}$ & $\begin{array}{l}-0.021 \\
(-2.37)\end{array}$ & ---- & $\begin{array}{l}-0.005 \\
(-1.47)\end{array}$ \\
\hline$\hat{\beta}$ & $\begin{array}{c}1.037 \\
(14.07)\end{array}$ & $\begin{array}{c}0.938 \\
(10.22)\end{array}$ & $\begin{array}{c}1.338 \\
(10.24)\end{array}$ & $\begin{array}{c}1.171 \\
(15.47)\end{array}$ & $\begin{array}{c}1.048 \\
(16.35)\end{array}$ & $\begin{array}{c}0.974 \\
(14.52)\end{array}$ & -- -- & $\begin{array}{c}1.121 \\
(21.87)\end{array}$ & $\begin{array}{l}1.259 \\
(8.69)\end{array}$ & ---- & $\begin{array}{c}1.096 \\
(19.81)\end{array}$ \\
\hline$\hat{s}$ & $\begin{array}{l}0.682 \\
(3.25)\end{array}$ & $\begin{array}{l}0.420 \\
(2.99)\end{array}$ & $\begin{array}{l}0.495 \\
(1.95)\end{array}$ & $\begin{array}{l}0.648 \\
(3.38)\end{array}$ & $\begin{array}{l}0.448 \\
(5.15)\end{array}$ & $\begin{array}{l}0.454 \\
(1.50)\end{array}$ & -- -- & $\begin{array}{l}0.558 \\
(4.06)\end{array}$ & $\begin{array}{l}0.219 \\
(0.87)\end{array}$ & -- -- & $\begin{array}{l}0.562 \\
(3.65)\end{array}$ \\
\hline$\hat{h}$ & $\begin{array}{l}-0.628 \\
(-5.85)\end{array}$ & $\begin{array}{l}-0.505 \\
(-3.89)\end{array}$ & $\begin{array}{l}-0.469 \\
(-2.48)\end{array}$ & $\begin{array}{l}-0.431 \\
(-3.40)\end{array}$ & $\begin{array}{l}-0.551 \\
(-5.22)\end{array}$ & $\begin{array}{l}-0.565 \\
(-3.95)\end{array}$ & --- & $\begin{array}{l}-0.558 \\
(-6.20)\end{array}$ & $\begin{array}{l}-0.852 \\
(-5.63)\end{array}$ & --- & $\begin{array}{l}-0.560 \\
(-5.92)\end{array}$ \\
\hline $\operatorname{Adj} R^{2}$ & 0.7667 & 0.5581 & 0.5582 & 0.7483 & 0.7310 & 0.6272 & -- -- & 0.8112 & 0.5542 & -- -- & 0.8234 \\
\hline
\end{tabular}




\begin{tabular}{|c|c|c|c|c|c|c|c|c|c|c|c|}
\hline & Financials & Comm. & $\begin{array}{c}\text { Basic } \\
\text { Materials }\end{array}$ & $\begin{array}{c}\text { Cons } \\
\text { cyclical }\end{array}$ & $\begin{array}{l}\text { Cons non- } \\
\text { cyclical }\end{array}$ & Diversified & Energy & Industrial & Tech & Utilities & $\overline{\text { Overall }}$ \\
\hline \multicolumn{12}{|l|}{ Philippines } \\
\hline$\hat{\alpha}$ & $\begin{array}{l}-0.005 \\
(-0.66)\end{array}$ & $\begin{array}{l}-0.003 \\
(-0.39)\end{array}$ & $\begin{array}{l}0.082 \\
(1.84)\end{array}$ & $\begin{array}{l}0.004 \\
(0.34)\end{array}$ & -- -- & -- -- & $\begin{array}{l}-0.002 \\
(-0.17)\end{array}$ & $\begin{array}{l}-0.001 \\
(-0.11)\end{array}$ & -- -- & ---- & $\begin{array}{l}0.014 \\
(1.36)\end{array}$ \\
\hline$\hat{\beta}$ & $\begin{array}{c}0.923 \\
(10.44)\end{array}$ & $\begin{array}{l}0.826 \\
(7.64)\end{array}$ & $\begin{array}{l}0.230 \\
(0.32)\end{array}$ & $\begin{array}{l}0.858 \\
(8.82)\end{array}$ & -- -- & -- -- & $\begin{array}{l}1.017 \\
(7.46)\end{array}$ & $\begin{array}{l}0.802 \\
(8.43)\end{array}$ & -- -- & -- -- & $\begin{array}{l}0.748 \\
(4.95)\end{array}$ \\
\hline$\hat{s}$ & $\begin{array}{l}0.209 \\
(1.01)\end{array}$ & $\begin{array}{l}0.038 \\
(0.15)\end{array}$ & $\begin{array}{l}9.948 \\
(2.41)\end{array}$ & $\begin{array}{l}-0.056 \\
(-0.23)\end{array}$ & -- -- & -- -- & $\begin{array}{l}-0.183 \\
(-0.49)\end{array}$ & $\begin{array}{l}0.209 \\
(0.89)\end{array}$ & -- -- & -- -- & $\begin{array}{l}2.049 \\
(2.80)\end{array}$ \\
\hline$\hat{h}$ & $\begin{array}{l}-0.381 \\
(-2.18)\end{array}$ & $\begin{array}{l}-0.268 \\
(-1.22)\end{array}$ & $\begin{array}{l}4.484 \\
(1.96)\end{array}$ & $\begin{array}{l}-0.232 \\
(-1.21)\end{array}$ & -- -- & -- -- & $\begin{array}{l}0.110 \\
(0.36)\end{array}$ & $\begin{array}{l}-0.244 \\
(-1.27)\end{array}$ & -- -- & -- -- & $\begin{array}{l}0.675 \\
(1.72)\end{array}$ \\
\hline Adj $R^{2}$ & 0.4503 & 0.3123 & 0.3899 & 0.1821 & -- -- & -- -- & 0.1584 & 0.3340 & ---- & -- -- & 0.4212 \\
\hline \multicolumn{12}{|l|}{ Japan } \\
\hline$\hat{\alpha}$ & $\begin{array}{l}-0.006 \\
(-0.80)\end{array}$ & $\begin{array}{l}-0.010 \\
(-1.29)\end{array}$ & $\begin{array}{l}-0.001 \\
(-0.22)\end{array}$ & $\begin{array}{l}-0.006 \\
(-1.70)\end{array}$ & $\begin{array}{l}-0.003 \\
(-0.76)\end{array}$ & -- -- & -- -- & $\begin{array}{l}-0.006 \\
(-1.76)\end{array}$ & $\begin{array}{l}-0.012 \\
(-3.23)\end{array}$ & $\begin{array}{l}0.003 \\
(0.85)\end{array}$ & $\begin{array}{l}-0.005 \\
(-1.50)\end{array}$ \\
\hline$\hat{\beta}$ & $\begin{array}{l}0.607 \\
(7.15)\end{array}$ & $\begin{array}{l}0.539 \\
(4.48)\end{array}$ & $\begin{array}{l}0.759 \\
(9.61)\end{array}$ & $\begin{array}{l}0.589 \\
(11.4)\end{array}$ & $\begin{array}{l}0.329 \\
(6.33)\end{array}$ & -- -- & -- -- & $\begin{array}{c}0.605 \\
(14.41)\end{array}$ & $\begin{array}{l}0.653 \\
(8.43)\end{array}$ & $\begin{array}{l}0.037 \\
(0.51)\end{array}$ & $\begin{array}{c}0.552 \\
(12.70)\end{array}$ \\
\hline$\hat{s}$ & $\begin{array}{l}-0.199 \\
(-1.06)\end{array}$ & $\begin{array}{l}-0.504 \\
(-1.78)\end{array}$ & $\begin{array}{l}-0.327 \\
(-1.92)\end{array}$ & $\begin{array}{l}-0.235 \\
(-1.89)\end{array}$ & $\begin{array}{l}-0.075 \\
(-0.61)\end{array}$ & -- -- & -- -- & $\begin{array}{l}-0.352 \\
(-2.80)\end{array}$ & $\begin{array}{l}-0.348 \\
(-3.17)\end{array}$ & $\begin{array}{l}-0.039 \\
(-0.36)\end{array}$ & $\begin{array}{l}-0.259 \\
(-2.22)\end{array}$ \\
\hline$\hat{h}$ & $\begin{array}{l}-0.486 \\
(-3.10)\end{array}$ & $\begin{array}{l}-0.465 \\
(-3.03)\end{array}$ & $\begin{array}{l}-0.305 \\
(-2.83)\end{array}$ & $\begin{array}{l}-0.370 \\
(-4.21)\end{array}$ & $\begin{array}{l}-0.248 \\
(-2.38)\end{array}$ & -- -- & -- -- & $\begin{array}{l}-0.379 \\
(-5.33)\end{array}$ & $\begin{array}{l}-0.400 \\
(-5.43)\end{array}$ & $\begin{array}{l}-0.229 \\
(-2.19)\end{array}$ & $\begin{array}{l}-0.369 \\
(-4.63)\end{array}$ \\
\hline $\operatorname{Adj} R^{2}$ & 0.2995 & 0.2329 & 0.4056 & 0.5711 & 0.2718 & ---- & ---- & 0.5708 & 0.5393 & 0.0525 & 0.5423 \\
\hline South Korea & & & & & & & & & & & \\
\hline$\hat{\alpha}$ & $\begin{array}{l}0.004 \\
(0.61)\end{array}$ & $\begin{array}{l}-0.008 \\
(-1.68)\end{array}$ & $\begin{array}{l}0.005 \\
(0.61)\end{array}$ & $\begin{array}{l}0.007 \\
(1.00)\end{array}$ & $\begin{array}{l}0.001 \\
(0.22)\end{array}$ & -- -- & $\begin{array}{l}-0.008 \\
(-1.32)\end{array}$ & $\begin{array}{l}0.009 \\
(1.68)\end{array}$ & $\begin{array}{l}-0.002 \\
(-0.26)\end{array}$ & $\begin{array}{l}0.002 \\
(0.23)\end{array}$ & $\begin{array}{l}0.004 \\
(0.90)\end{array}$ \\
\hline$\hat{\beta}$ & $\begin{array}{c}1.462 \\
(13.35)\end{array}$ & $\begin{array}{l}0.793 \\
(7.22)\end{array}$ & $\begin{array}{l}0.969 \\
(4.89)\end{array}$ & $\begin{array}{c}0.892 \\
(11.00)\end{array}$ & $\begin{array}{c}1.06 \\
(10.89)\end{array}$ & -- -- & $\begin{array}{l}1.208 \\
(7.58)\end{array}$ & $\begin{array}{c}1.405 \\
(13.21)\end{array}$ & $\begin{array}{l}1.352 \\
(8.35)\end{array}$ & $\begin{array}{l}0.681 \\
(3.90)\end{array}$ & $\begin{array}{c}1.260 \\
(15.56)\end{array}$ \\
\hline$\hat{s}$ & $\begin{array}{l}-0.986 \\
(-5.00)\end{array}$ & $\begin{array}{l}-0.862 \\
(-5.29)\end{array}$ & $\begin{array}{l}-0.589 \\
(-2.53)\end{array}$ & $\begin{array}{l}-0.222 \\
(-1.37)\end{array}$ & $\begin{array}{l}-0.496 \\
(-3.02)\end{array}$ & --- & $\begin{array}{l}-0.775 \\
(-2.84)\end{array}$ & $\begin{array}{l}-0.698 \\
(-3.75)\end{array}$ & $\begin{array}{l}-0.768 \\
(-5.04)\end{array}$ & $\begin{array}{l}-0.252 \\
(-1.57)\end{array}$ & $\begin{array}{l}-0.700 \\
(-4.64)\end{array}$ \\
\hline$\hat{h}$ & $\begin{array}{l}-0.769 \\
(-6.25)\end{array}$ & $\begin{array}{l}-0.681 \\
(-4.15)\end{array}$ & $\begin{array}{l}-0.572 \\
(-1.53)\end{array}$ & $\begin{array}{l}-0.299 \\
(-1.59)\end{array}$ & $\begin{array}{l}-0.733 \\
(-4.86)\end{array}$ & -- -- & $\begin{array}{l}-0.490 \\
(-2.80)\end{array}$ & $\begin{array}{l}-0.594 \\
(-3.76)\end{array}$ & $\begin{array}{l}-0.690 \\
(-4.44)\end{array}$ & $\begin{array}{l}-0.591 \\
(-3.31)\end{array}$ & $\begin{array}{l}-0.653 \\
(-5.44)\end{array}$ \\
\hline $\operatorname{Adj} R^{2}$ & 0.6273 & 0.5008 & 0.3410 & 0.4388 & 0.6024 & -- -- & 0.5203 & 0.6925 & 0.5943 & 0.2237 & 0.7342 \\
\hline
\end{tabular}

Notes: (1) The risk free rate is the 10 year yield on US Treasury instruments adjusted for monthly values.

(2) Numbers in parentheses are Newey-West HAC covariance adjusted t-statistics. 
Table 7 Time varying CAPM model parameters

\begin{tabular}{|c|c|c|c|c|c|c|c|c|c|c|c|}
\hline Country & & $\begin{array}{l}\text { Overall } \\
\text { Mean }\end{array}$ & $\begin{array}{c}\text { Overall High/ } \\
\text { Low }\end{array}$ & 2003 & 2004 & 2005 & 2006 & 2007 & 2008 & 2009 & $\begin{array}{c}\text { Convergence } \\
\text { (Iterations) }\end{array}$ \\
\hline Australia & Constant & -- -- & -- -- & -- -- & -- -- & -- -- & -- -- & -- -- & -- -- & -- -- & No \\
\hline \multirow[t]{3}{*}{ Overall } & Market Beta & -- -- & -- -- & ---- & -- -- & ---- & -- -- & -- -- & -- -- & -- -- & convergence \\
\hline & Size Beta & -- -- & -- -- & -- -- & -- -- & -- -- & -- -- & -- -- & -- -- & -- -- & \\
\hline & Illiquidity Beta & -- -- & -- -- & ---- & -- -- & -- -- & -- -- & -- -- & -- -- & -- -- & \\
\hline New Zealand & Constant & -0.007 & $0.057 /-0.105$ & 0.010 & 0.019 & -0.003 & -0.017 & -0.029 & -0.008 & -0.007 & 11 \\
\hline \multirow{3}{*}{ Overall } & Market Beta & 0.793 & $0.833 / 0.689$ & 0.843 & 0.797 & 0.818 & 0.813 & 0.800 & 0.738 & 0.748 & \\
\hline & Size Beta & -- -- & -- -- & -- -- & -- -- & -- -- & -- -- & -- -- & -- -- & -- -- & \\
\hline & Illiquidity Beta & -- -- & -- -- & -- -- & -- -- & -- -- & -- -- & -- -- & -- -- & -- -- & \\
\hline Indonesia & Constant & -- -- & -- -- & -- -- & -- -- & -- -- & -- -- & -- -- & -- -- & -- -- & No \\
\hline \multirow[t]{3}{*}{ Overall } & Market Beta & -- -- & -- -- & -- -- & -- -- & -- -- & -- -- & -- -- & -- -- & -- -- & convergence \\
\hline & Size Beta & -- -- & -- -- & -- -- & -- -- & -- -- & -- -- & -- -- & ---- & -- -- & \\
\hline & Illiquidity Beta & -- -- & -- -- & -- -- & -- -- & -- -- & -- -- & -- -- & -- -- & -- -- & \\
\hline Malaysia & Constant & -0.006 & $0.046 /-0.067$ & -0.008 & -0.004 & -0.013 & 0.000 & -0.005 & -0.010 & 0.011 & 84 \\
\hline \multirow[t]{3}{*}{ Overall } & Market Beta & 0.838 & $1.946 /-0.061$ & 0.938 & 1.183 & 0.755 & 0.806 & 0.922 & 0.522 & 0.295 & \\
\hline & Size Beta & 0.055 & $0.766 /-0.725$ & 0.627 & 0.236 & 0.006 & -0.317 & 0.401 & -0.049 & 0.068 & \\
\hline & Illiquidity Beta & 0.239 & $0.628 /-0.205$ & 0.499 & 0.519 & 0.480 & 0.307 & -0.006 & -0.107 & -0.155 & \\
\hline Thailand & Constant & -0.020 & $0.109 /-0.151$ & 0.051 & -0.027 & -0.012 & -0.009 & -0.047 & -0.006 & 0.012 & 29 \\
\hline \multirow[t]{3}{*}{ Overall } & Market Beta & 1.305 & $1.974 / 0.692$ & 1.474 & 1.691 & 1.367 & 1.264 & 1.309 & 0.894 & 0.916 & \\
\hline & Size Beta & -- -- & -- -- & -- -- & -- -- & -- -- & -- -- & -- -- & -- -- & -- -- & \\
\hline & Illiquidity Beta & -0.117 & $0.131 /-0.429$ & -0.134 & -0.300 & -0.222 & -0.094 & -0.049 & 0.081 & 0.228 & \\
\hline Hong Kong & Constant & -0.007 & $0.060 /-0.071$ & 0.002 & -0.002 & -0.008 & -0.013 & -0.017 & 0.003 & 0.001 & 16 \\
\hline \multirow[t]{3}{*}{ Overall } & Market Beta & 1.197 & $1.235 / 1.092$ & 1.233 & 1.224 & 1.214 & 1.213 & 1.184 & 1.149 & 1.083 & \\
\hline & Size Beta & 0.047 & $0.877 /-0.556$ & 0.176 & 0.626 & 0.139 & -0.184 & -0.309 & -0.036 & 0.413 & \\
\hline & Illiquidity Beta & -- -- & -- -- & ---- & ---- & -- -- & -- -- & -- -- & -- -- & ---- & \\
\hline China Shenzen & Constant & 0.003 & $0.078 /-0.102$ & -0.023 & -0.012 & -0.010 & 0.007 & 0.018 & 0.012 & -0.011 & 24 \\
\hline \multirow[t]{3}{*}{ Overall } & Market Beta & 1.316 & $1.738 / 0.690$ & 1.297 & 0.976 & 1.487 & 1.437 & 1.163 & 1.515 & 1.762 & \\
\hline & Size Beta & 0.088 & $0.378 /-0.226$ & -0.109 & 0.029 & 0.227 & 0.239 & 0.088 & -0.146 & -0.375 & \\
\hline & Illiquidity Beta & 0.919 & $1.946 /-0.509$ & 1.041 & -0.105 & 0.622 & 1.156 & 1.260 & 1.665 & 1.745 & \\
\hline China & Constant & -0.001 & $0.058 /-0.110$ & -0.023 & -0.009 & -0.006 & -0.002 & 0.014 & 0.000 & -0.012 & 31 \\
\hline Shanghai & Market Beta & 1.203 & $1.583 / 0.454$ & 1.171 & 0.746 & 1.378 & 1.327 & 1.156 & 1.408 & 1.663 & \\
\hline
\end{tabular}




\begin{tabular}{|c|c|c|c|c|c|c|c|c|c|c|c|}
\hline Overall & $\begin{array}{l}\text { Size Beta } \\
\text { Illiquidity Beta }\end{array}$ & $\begin{array}{l}0.315 \\
0.829\end{array}$ & $\begin{array}{l}0.764 /-0.151 \\
1.845 /-0.631\end{array}$ & $\begin{array}{l}0.042 \\
1.044\end{array}$ & $\begin{array}{l}0.201 \\
-0.254\end{array}$ & $\begin{array}{l}0.526 \\
0.434\end{array}$ & $\begin{array}{l}0.525 \\
0.961\end{array}$ & $\begin{array}{l}0.313 \\
1.481\end{array}$ & $\begin{array}{l}0.010 \\
1.521\end{array}$ & $\begin{array}{l}-0.589 \\
1.457\end{array}$ & \\
\hline $\begin{array}{l}\text { Singapore } \\
\text { Overall }\end{array}$ & $\begin{array}{l}\text { Constant } \\
\text { Market Beta } \\
\text { Size Beta } \\
\text { Illiquidity Beta }\end{array}$ & $\begin{array}{c}0.008 \\
0.834 \\
0.242 \\
-0.503\end{array}$ & $\begin{array}{c}0.094 /-0.053 \\
1.038 / 0.743 \\
1.369 /-1.135 \\
-0.376 /-0.664\end{array}$ & $\begin{array}{l}-0.025 \\
0.822 \\
0.975 \\
-0.693\end{array}$ & $\begin{array}{c}-0.004 \\
0.844 \\
0.765 \\
-0.606\end{array}$ & $\begin{array}{c}0.002 \\
0.774 \\
-0.190 \\
-0.517\end{array}$ & $\begin{array}{c}0.027 \\
0.758 \\
-0.430 \\
-0.424\end{array}$ & $\begin{array}{c}0.026 \\
0.797 \\
0.559 \\
-0.460\end{array}$ & $\begin{array}{c}-0.009 \\
0.997 \\
0.506 \\
-0.505\end{array}$ & $\begin{array}{c}-0.001 \\
1.000 \\
0.918 \\
-0.336\end{array}$ & 55 \\
\hline $\begin{array}{l}\text { Philippines } \\
\text { Overall }\end{array}$ & $\begin{array}{l}\text { Constant } \\
\text { Market Beta } \\
\text { Size Beta } \\
\text { Illiquidity Beta }\end{array}$ & $\begin{array}{l}0.050 \\
0.303 \\
0.669 \\
0.115\end{array}$ & $\begin{array}{l}0.345 /-0.075 \\
1.415 /-0.426 \\
4.558 /-1.074 \\
0.771 /-0.609\end{array}$ & $\begin{array}{c}0.050 \\
0.130 \\
-0.141 \\
0.361\end{array}$ & $\begin{array}{l}0.042 \\
0.040 \\
0.088 \\
0.716\end{array}$ & $\begin{array}{c}0.089 \\
-0.182 \\
1.866 \\
0.557\end{array}$ & $\begin{array}{l}0.048 \\
0.231 \\
0.438 \\
0.000\end{array}$ & $\begin{array}{c}0.057 \\
0.274 \\
0.541 \\
-0.386\end{array}$ & $\begin{array}{c}0.012 \\
1.150 \\
0.413 \\
-0.313\end{array}$ & $\begin{array}{c}0.000 \\
0.868 \\
0.418 \\
-0.013\end{array}$ & 61 \\
\hline Japan Overall & $\begin{array}{l}\text { Constant } \\
\text { Market Beta } \\
\text { Size Beta } \\
\text { Illiquidity Beta }\end{array}$ & $\begin{array}{c}-0.011 \\
0.674 \\
-0.757 \\
-0.104\end{array}$ & $\begin{array}{c}0.093 /-0.077 \\
0.868 / 0.326 \\
-0.095 /-1.773 \\
0.021 /-0.337\end{array}$ & $\begin{array}{l}0.021 \\
0.643 \\
-1.024 \\
-0.179\end{array}$ & $\begin{array}{c}-0.007 \\
0.829 \\
-1.334 \\
-0.017\end{array}$ & $\begin{array}{c}-0.010 \\
0.780 \\
-1.196 \\
-0.021\end{array}$ & $\begin{array}{c}-0.006 \\
0.736 \\
-0.538 \\
-0.038\end{array}$ & $\begin{array}{c}-0.023 \\
0.621 \\
-0.428 \\
-0.166\end{array}$ & $\begin{array}{l}-0.010 \\
0.402 \\
-0.289 \\
-0.279\end{array}$ & $\begin{array}{l}-0.019 \\
0.459 \\
-0.067 \\
-0.395\end{array}$ & 78 \\
\hline $\begin{array}{l}\text { South Korea } \\
\text { Overall }\end{array}$ & $\begin{array}{l}\text { Constant } \\
\text { Market Beta } \\
\text { Size Beta } \\
\text { Illiquidity Beta }\end{array}$ & $\begin{array}{c}-0.009 \\
1.540 \\
-1.120 \\
-0.254\end{array}$ & $\begin{array}{c}0.072 /-0.139 \\
1.792 / 1.043 \\
-0.849 /-1.286 \\
0.118 /-0.551\end{array}$ & $\begin{array}{l}-0.017 \\
1.867 \\
-1.048 \\
-0.206\end{array}$ & $\begin{array}{l}-0.009 \\
1.670 \\
-1.112 \\
-0.110\end{array}$ & $\begin{array}{r}0.013 \\
1.625 \\
-1.141 \\
-0.338\end{array}$ & $\begin{array}{l}-0.015 \\
1.550 \\
-1.215 \\
-0.222\end{array}$ & $\begin{array}{l}-0.031 \\
1.557 \\
-1.207 \\
-0.205\end{array}$ & $\begin{array}{l}-0.005 \\
1.298 \\
-0.925 \\
-0.397\end{array}$ & $\begin{array}{l}-0.013 \\
1.203 \\
-1.072 \\
-1.271\end{array}$ & 51 \\
\hline
\end{tabular}


Table 8 Cost of equity estimates

\begin{tabular}{|c|c|c|c|c|c|c|c|c|c|c|c|c|}
\hline & Australia & $\begin{array}{c}\text { New } \\
\text { Zealand }\end{array}$ & Indonesia & Singapore & Malaysia & Thailand & $\begin{array}{l}\text { Hong } \\
\text { Kong }\end{array}$ & $\begin{array}{c}\text { China } \\
\text { Shenzen }\end{array}$ & $\begin{array}{c}\text { China } \\
\text { Shanghai }\end{array}$ & Philippines & Japan & $\begin{array}{l}\text { South } \\
\text { Korea }\end{array}$ \\
\hline \multicolumn{13}{|c|}{ Panel 1: Size-Liquidity CAPM } \\
\hline Financials & 17.71 & 14.93 & 20.84 & 25.82 & 17.77 & 27.01 & 23.48 & 26.43 & 24.23 & 21.44 & 13.22 & 26.35 \\
\hline Comm. & 21.13 & 14.15 & 21.29 & 22.67 & 13.24 & 22.90 & 27.38 & 26.69 & 23.08 & 18.76 & 10.47 & 13.74 \\
\hline Basic Materials & 23.84 & 18.59 & 29.84 & 30.97 & 16.69 & 23.47 & 29.44 & 29.15 & 28.24 & 55.36 & 15.71 & 18.54 \\
\hline Cons cyclical & 18.80 & 17.62 & 28.08 & 28.39 & 15.12 & 18.65 & 22.45 & 22.94 & 27.07 & 18.99 & 12.76 & 18.85 \\
\hline Cons non-cyclical & 13.44 & 14.33 & -- -- & 24.97 & 12.12 & 23.47 & 19.05 & 22.86 & 22.70 & -- -- & 8.40 & 20.70 \\
\hline Diversified & -- -- & 15.84 & -- -- & 23.52 & 23.66 & -- -- & 22.55 & 26.73 & 31.75 & -- -- & -- -- & -- -- \\
\hline Energy & 17.50 & 15.33 & 25.89 & -- -- & 11.88 & 28.32 & 23.15 & 29.43 & 29.58 & 21.68 & -- -- & 22.43 \\
\hline Industrial & 20.52 & 14.91 & 34.61 & 26.94 & 14.76 & 27.40 & 24.85 & 24.15 & 24.97 & 19.10 & 24.14 & 26.65 \\
\hline Technology & 18.53 & 16.24 & 18.57 & 27.94 & 24.12 & 24.63 & 27.75 & 26.35 & 23.37 & -- -- & 13.47 & 25.25 \\
\hline Utilities & 13.56 & 13.58 & -- -- & -- -- & 12.84 & 15.09 & 15.15 & 22.74 & 23.70 & -- -- & 2.79 & 14.40 \\
\hline Overall & 18.92 & 15.40 & 29.21 & 26.45 & 16.33 & 24.31 & 23.77 & 25.96 & 25.38 & 27.03 & 11.91 & 23.76 \\
\hline \multicolumn{13}{|c|}{ Panel 2: Time-varying CAPM } \\
\hline Financials & 18.68 & 17.43 & 13.97 & 19.12 & 22.51 & 32.81 & 25.18 & 27.36 & 26.96 & 15.85 & ---- & 20.94 \\
\hline Comm. & 21.44 & 19.01 & 9.25 & 20.27 & 11.96 & 19.61 & 24.47 & 30.66 & 29.56 & 12.55 & 10.01 & 14.90 \\
\hline Basic Materials & 31.98 & 13.09 & ---- & 18.64 & 18.82 & -- -- & 29.77 & 32.94 & 32.01 & 11.72 & 20.05 & 30.29 \\
\hline Cons cyclical & 20.55 & 19.22 & 20.74 & 21.97 & 17.11 & 20.18 & -- -- & 20.67 & 29.55 & -- -- & 13.18 & 21.17 \\
\hline Cons non-cyclical & 16.37 & 17.38 & ---- & 23.71 & 13.36 & 12.67 & 18.51 & 28.72 & 20.64 & -- -- & 7.21 & 15.23 \\
\hline Diversified & -- -- & 15.59 & -- -- & 19.99 & 25.59 & -- -- & 22.18 & 30.29 & 27.60 & -- -- & -- -- & -- -- \\
\hline Energy & 20.37 & 19.03 & 19.76 & --- & 9.58 & 28.93 & 41.31 & 23.44 & 23.64 & 25.83 & -- -- & 19.52 \\
\hline Industrial & 14.68 & -- -- & 20.46 & 20.50 & 18.31 & 28.54 & 32.12 & 29.54 & 31.10 & 6.43 & 13.92 & 30.51 \\
\hline Technology & 16.33 & 11.42 & 31.00 & 26.09 & 19.15 & 6.63 & 27.04 & 26.42 & 25.11 & -- -- & 13.66 & 24.07 \\
\hline Utilities & -- -- & -- -- & -- -- & --- & 11.84 & 16.43 & 18.38 & 21.14 & 25.57 & -- -- & 5.11 & 8.85 \\
\hline Overall & ---- & 18.05 & & 19.79 & 19.29 & 28.15 & 26.27 & 29.20 & 28.00 & 11.52 & 12.10 & 27.50 \\
\hline
\end{tabular}


Figure 1 Malaysia time-varying liquidity beta

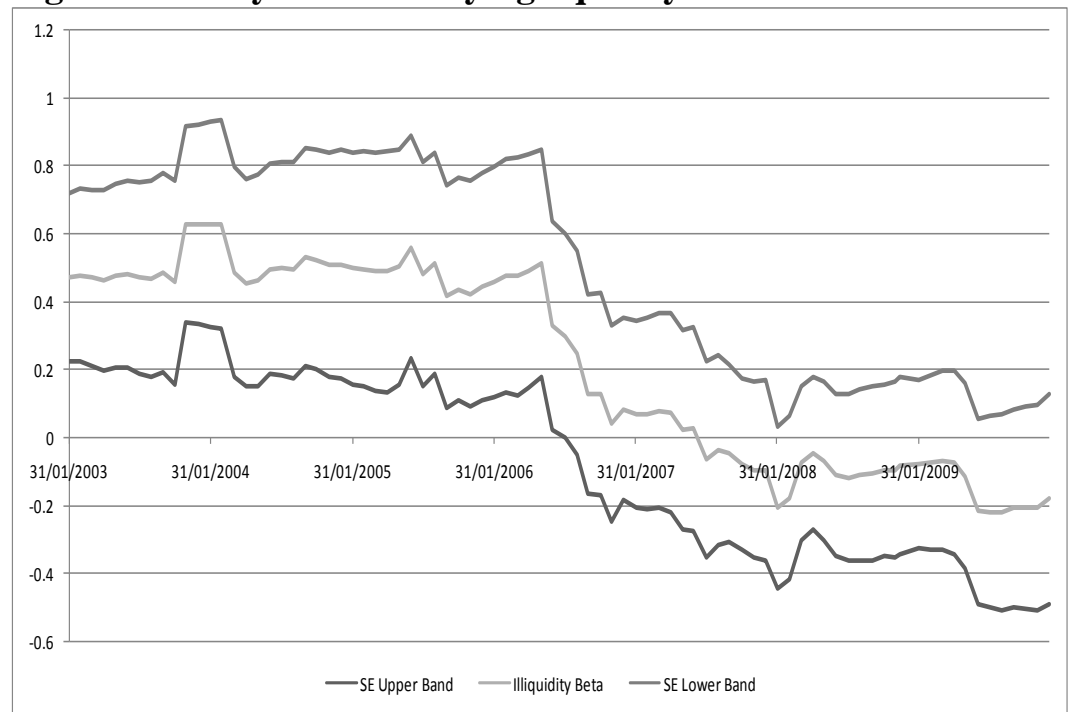

Figure 3 China Shenzen time-varying liquidity beta

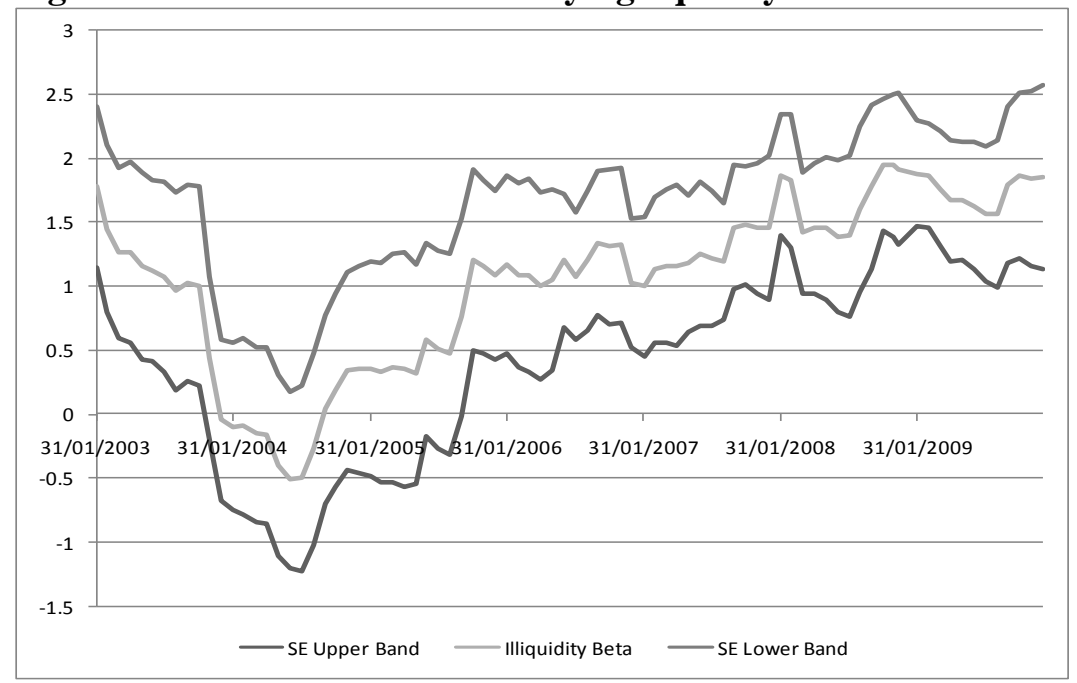

Figure 2 Thailand time-varying illiquidity beta

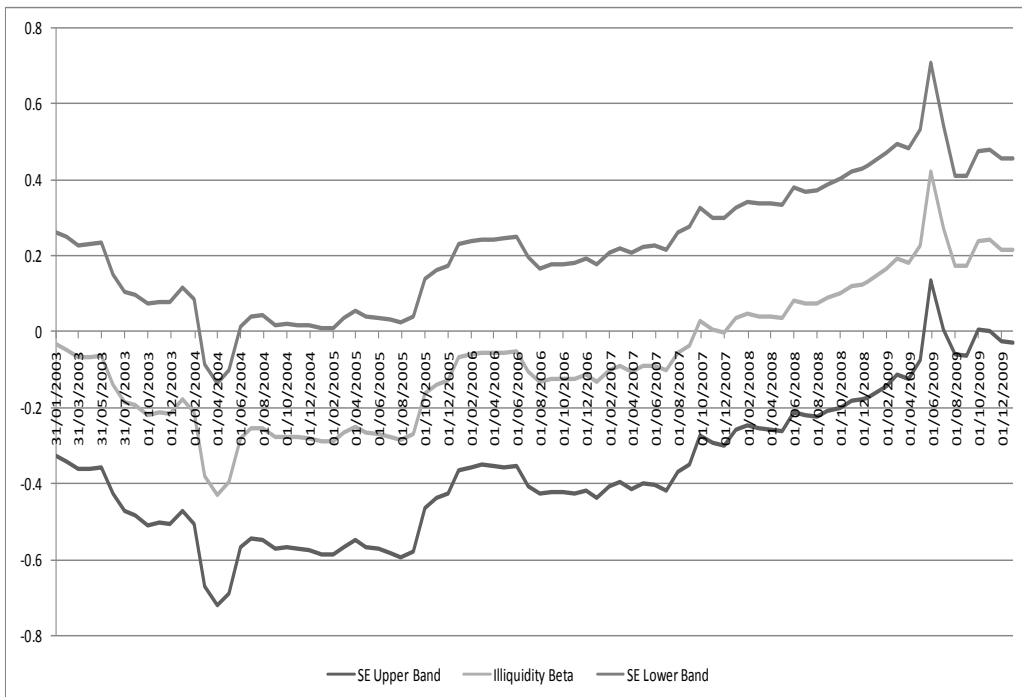

Figure 4 China Shanghai time-varying liquidity beta

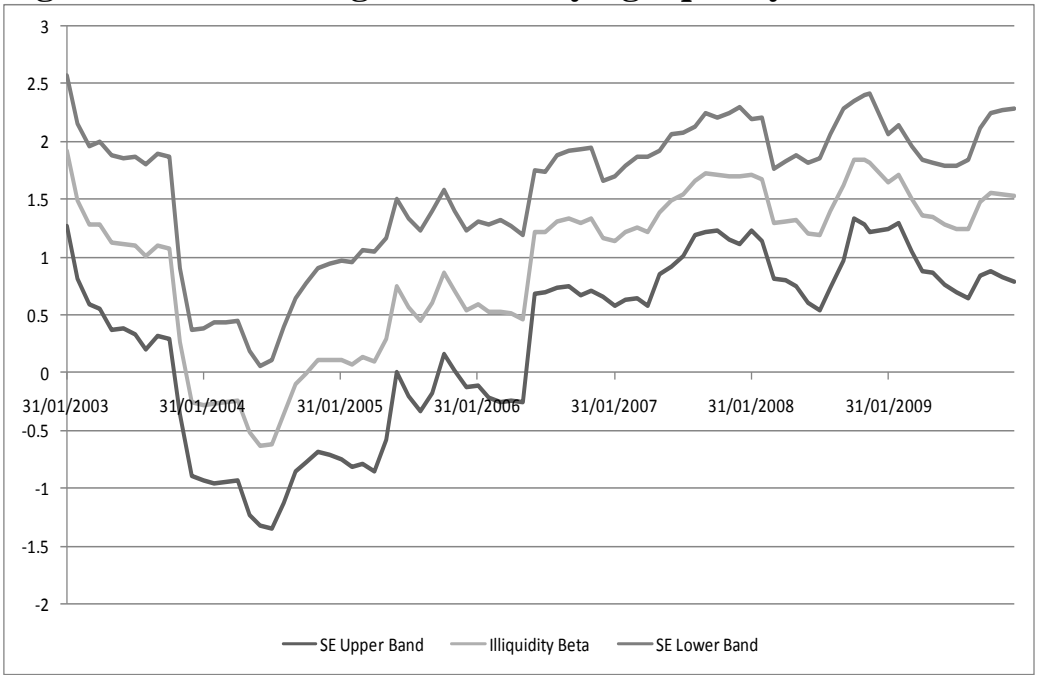


Figure 5 Singapore time-varying liquidity beta

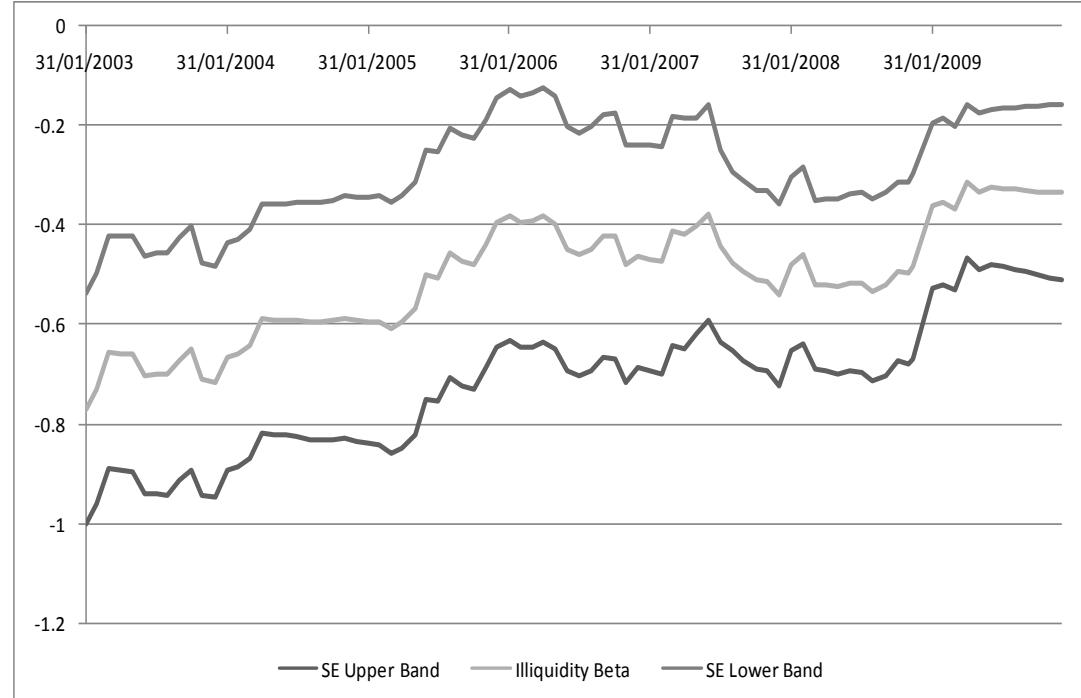

Figure 7 Japan time-varying liquidity beta

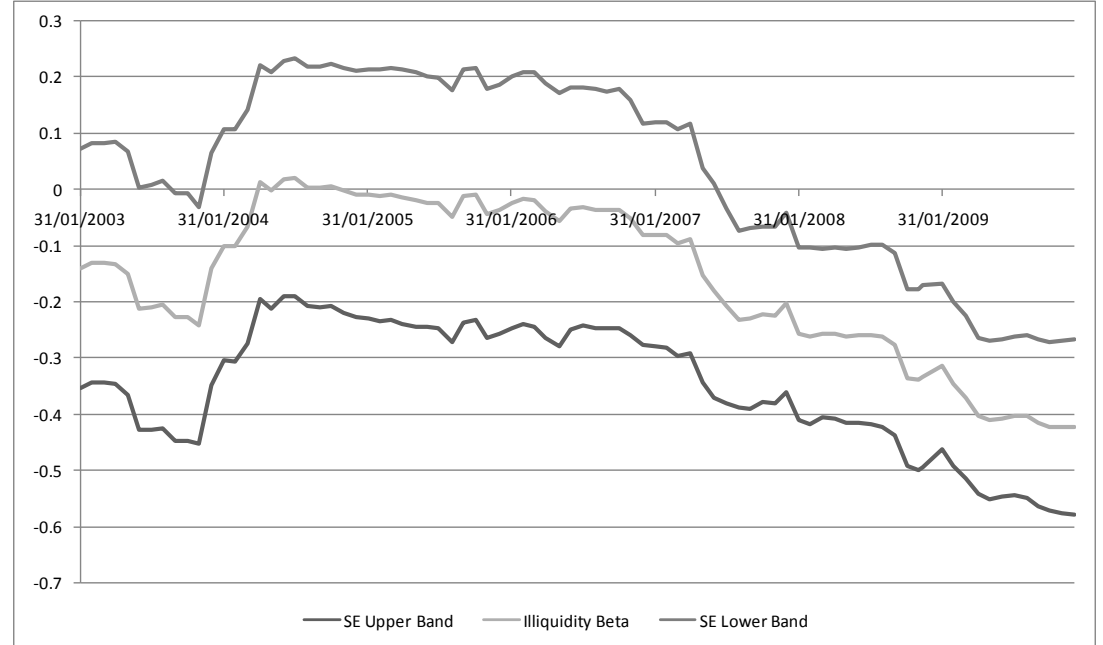

Figure 6 Philippines time-varying liquidity beta

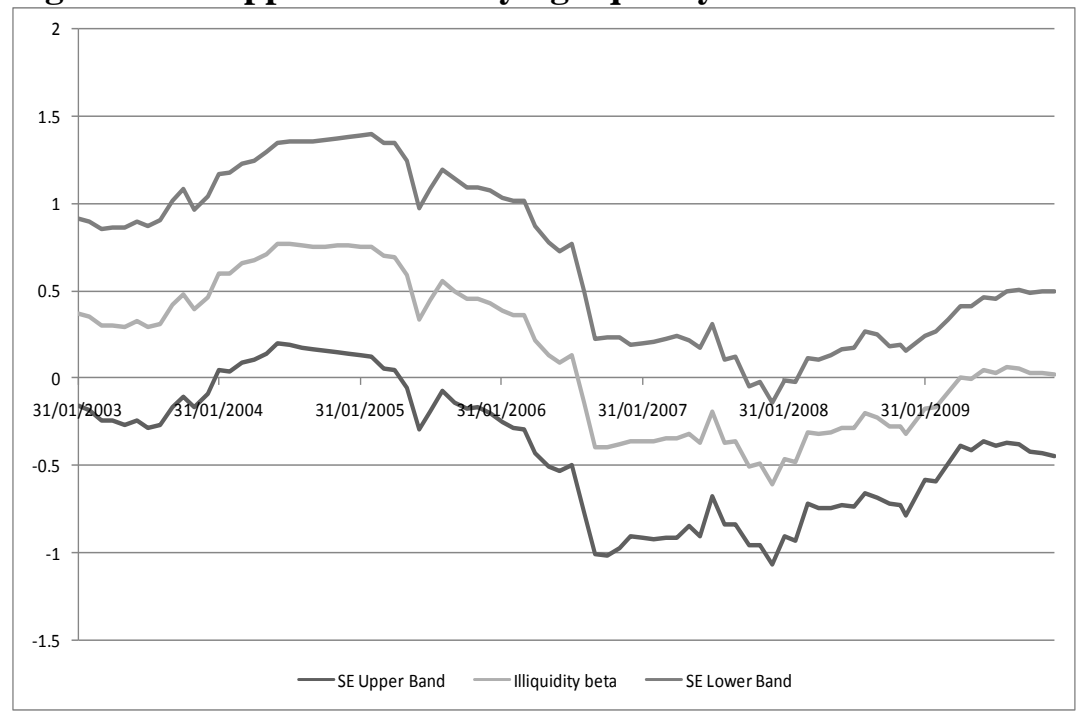

Figure 8 South Korea time-varying liquidity beta

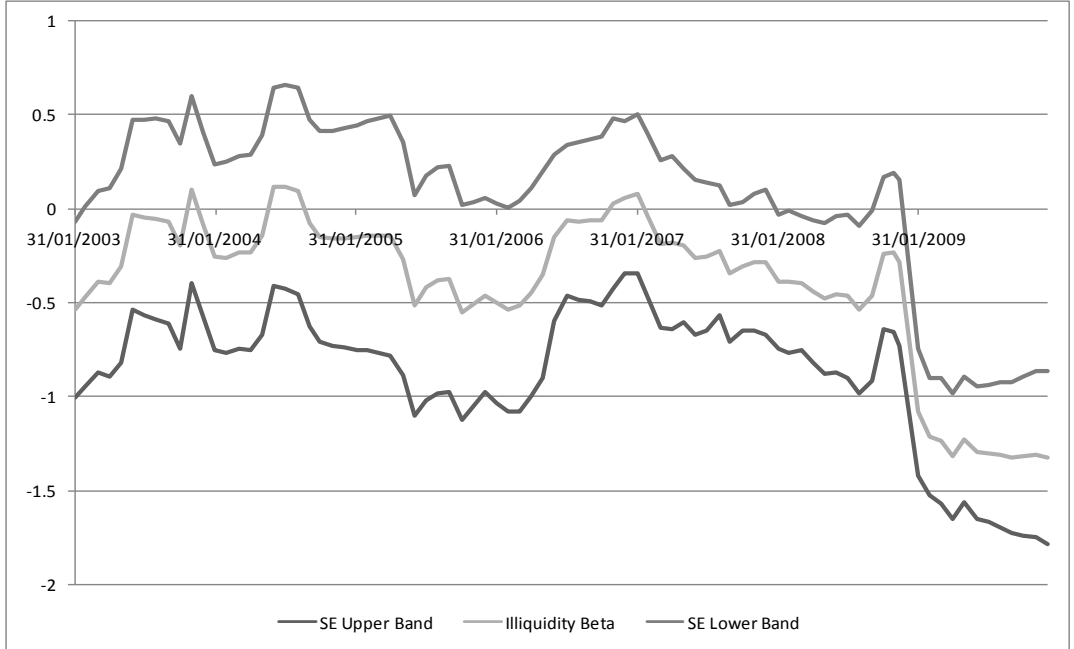


Figure 9 New Zealand Financials time-varying liquidity beta

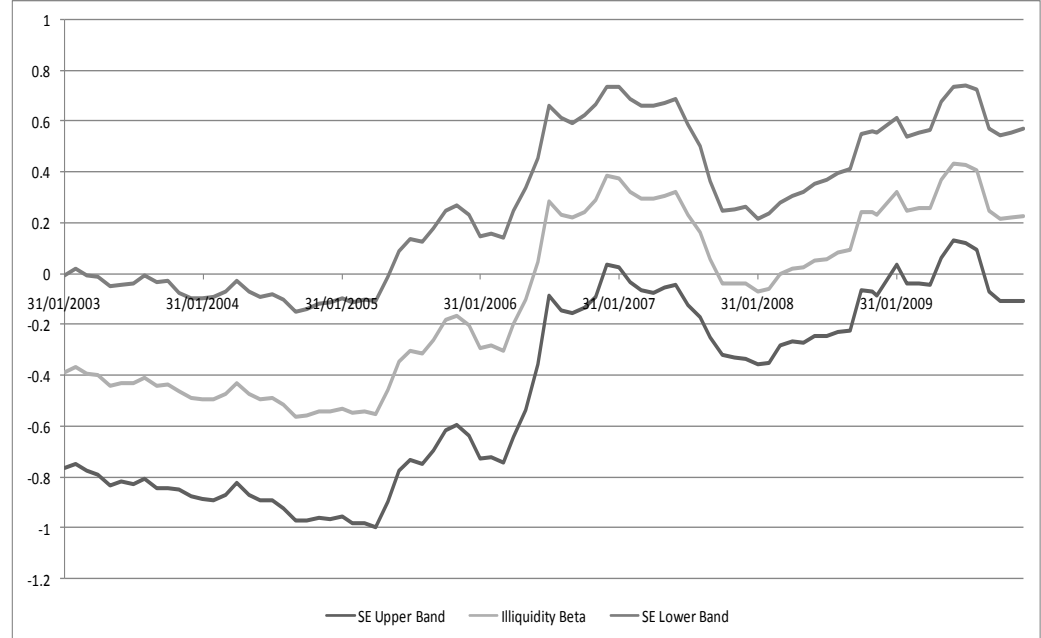

Figure 11 Singapore Financials time-varying liquidity beta

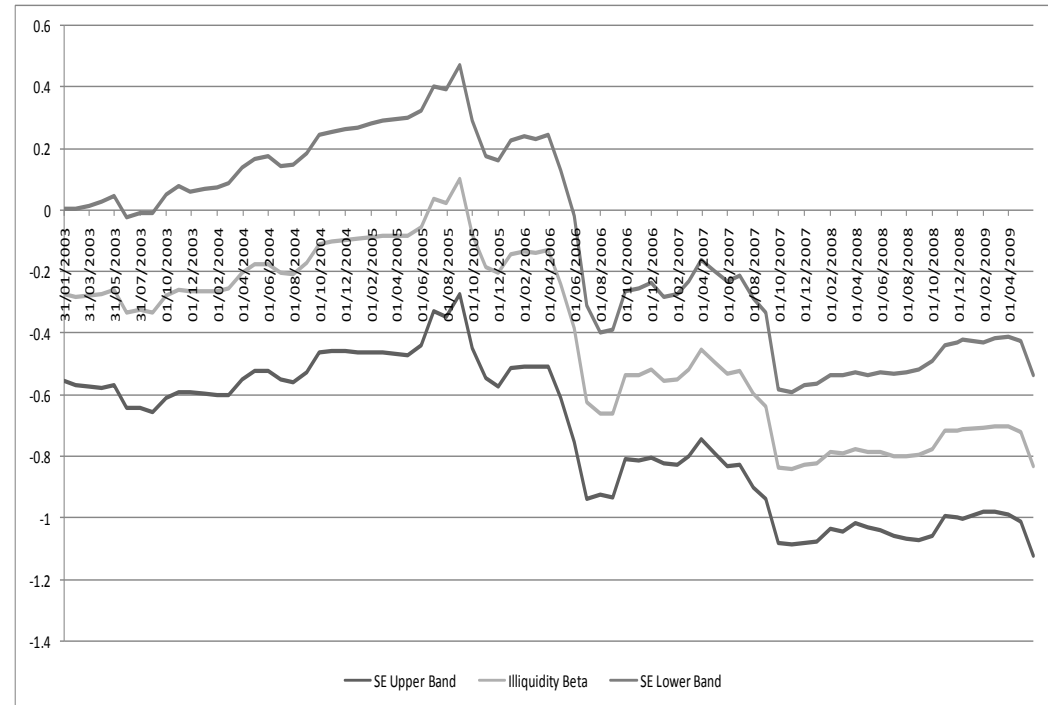

Figure 10 Indonesia Financials time-varying liquidity beta

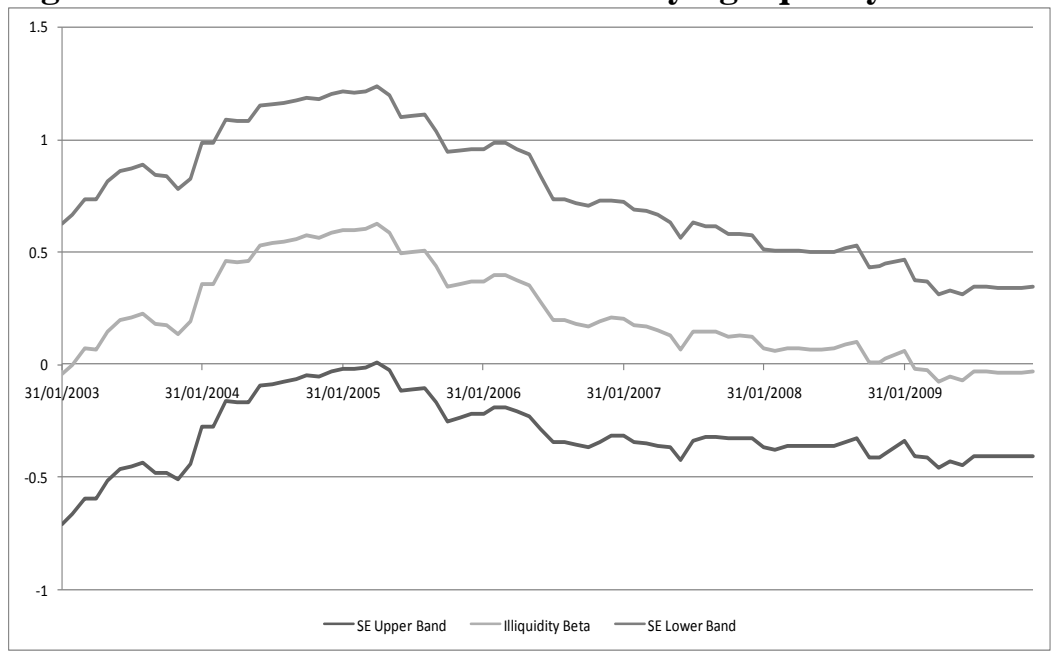

Figure 12 Malaysia Financials time-varying liquidity beta

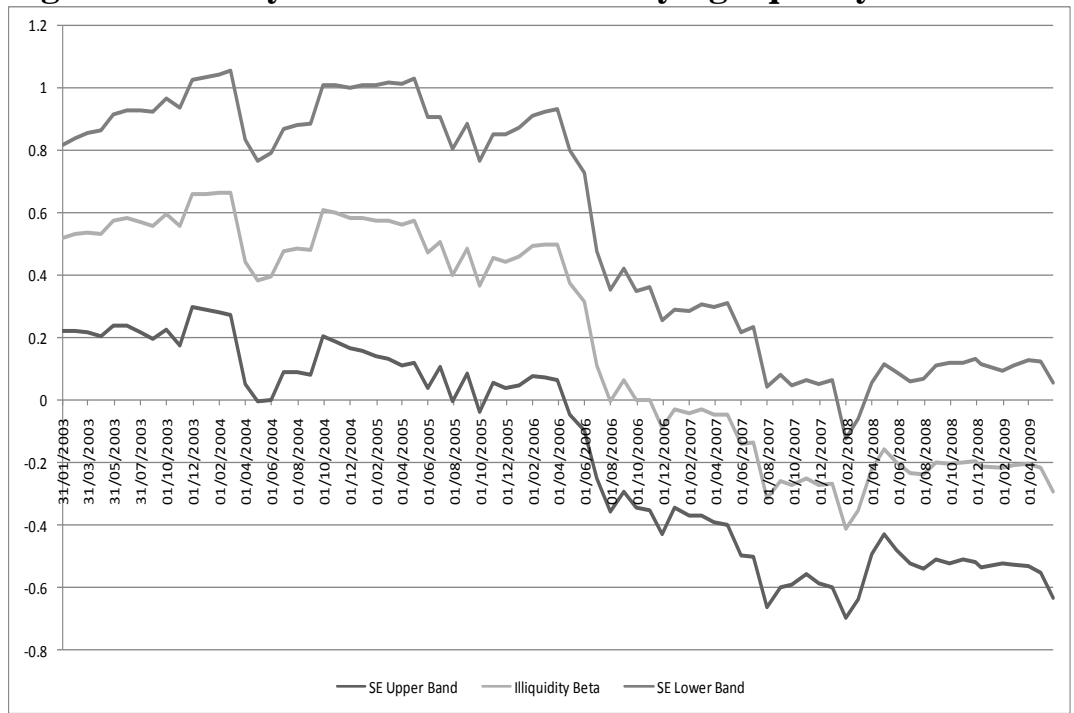


Figure 13 China Shenzen Financials time-varying liquidity beta

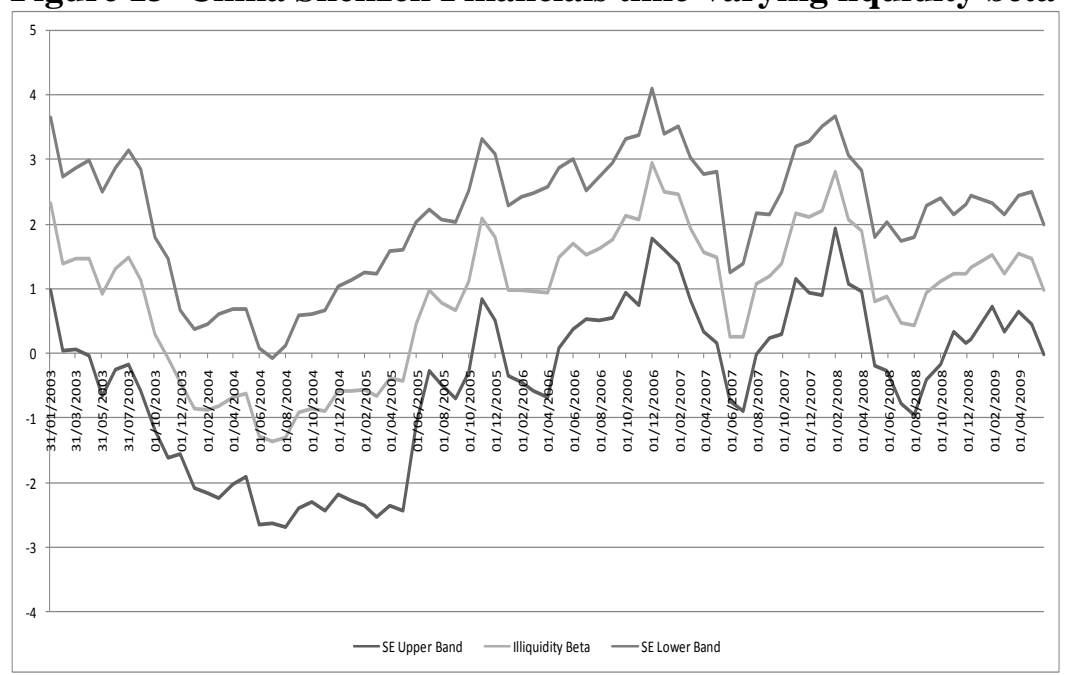

Figure 14 China Shanghai Financials time-varying liquidity beta

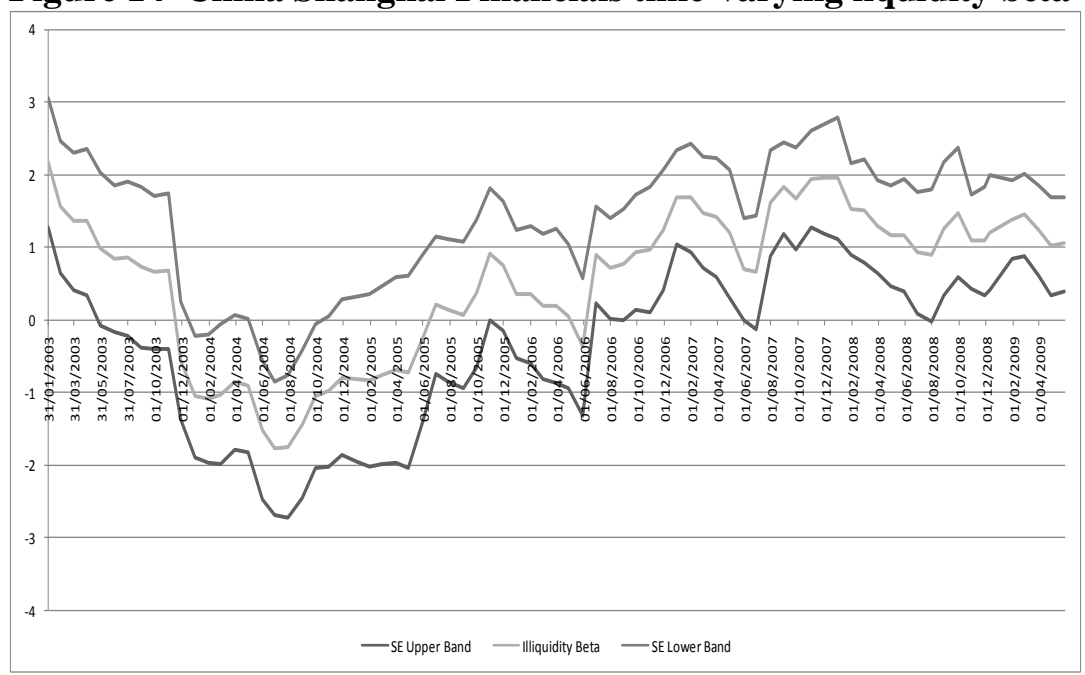




\begin{tabular}{|c|c|c|c|c|c|c|c|}
\hline Country & $\begin{array}{l}\text { Commercial } \\
\text { Law }\end{array}$ & Min no shareholders & $\begin{array}{l}\text { Min } \\
\text { amount } \\
\text { issued }\end{array}$ & $\begin{array}{l}\text { Min amount } \\
\text { issued (US\$) }\end{array}$ & $\begin{array}{l}\text { No shares } \\
\text { issued }\end{array}$ & Min sales & $\begin{array}{l}\text { No years } \\
\text { financial } \\
\text { statements }\end{array}$ \\
\hline Australia & Common Law & $\begin{array}{l}\text { Min. } 500 \text { shareholders each having a } \\
\text { parcel of main class of securities worth a } \\
\text { min. A } \$ 2000 \\
\text { or } \\
\text { Min. } 400 \text { investors each having a parcel of } \\
\text { main class of securities worth a min. } \\
\text { A } \$ 2000 \text { and } 25 \% \text { held by unrelated parties }\end{array}$ & $\mathrm{A} \$ 10 \mathrm{~m}$ & 9.78 & $\begin{array}{ll}--- \\
\end{array}$ & $\begin{array}{l}\text { Net profit after tax of } \mathrm{A} \$ 1.0 \text { million (in } \\
\text { aggregate) over the last } 3 \text { years plus } \mathrm{A} \$ 0.4 \\
\text { million over the last } 12 \text { months and your } \\
\text { organisation is still profitable }\end{array}$ & 3 years \\
\hline $\begin{array}{l}\text { New } \\
\text { Zealand }\end{array}$ & Common Law & $\begin{array}{l}\text { Min. } 500 \text { shareholders with } 25 \% \text { of total } \\
\text { issued equity }\end{array}$ & $\mathrm{NZ} \$ 5 \mathrm{~m}$ & 3.81 & -- -- & & \\
\hline Indonesia & Civil Code & Min. $30 \%$ to public & IDR $20 \mathrm{~b}$ & 2.20 & -- -- & Operating history for previous 3 years & 1 year \\
\hline Singapore & Common Law & $\begin{array}{l}\text { Min. } 1,000 \text { shareholders. Public float } \\
\text { must be } 25 \% \text { if issue }<\mathrm{S} \$ 300 \mathrm{~m} ; 20 \% \text { if } \\
\text { issue } \mathrm{S} \$ 300 \mathrm{~m} \text { to } \mathrm{S} \$ 400 \mathrm{~m} ; 15 \% \text { if issue } \\
\mathrm{S} 4400 \mathrm{~m} \text { to } \mathrm{S} \$ 1 \mathrm{~b} ; 12 \% \text { if issue }>\mathrm{S} \$ 1 \mathrm{~b}\end{array}$ & $\mathrm{~S} \$ 80 \mathrm{~m}$ & 61.00 & $400,000,000$ & $\begin{array}{l}\text { Min. cumulative profits of } S \$ 7.5 \mathrm{~m} \text { and a } \\
\text { min, profit of } S \$ 1 \mathrm{~m} \text { in each of } 3 \text { years }\end{array}$ & 3 years \\
\hline Malaysia & Common Law & $\begin{array}{l}\text { Min. 1,000 shareholders holding } 25 \% \text { each } \\
\text { holding min. } 100 \text { shares }\end{array}$ & & & & & \\
\hline Thailand & Common Law & Min 1,000 shareholders & THB 300m & 9.96 & & $\begin{array}{l}\text { Net profit characteristics: } \\
\text { 1. combined minimum net profits from } \\
\text { operations of THB 50m over the past two or } \\
\text { three years. } \\
\text { 2. net profits from operations of THB } 30 \\
\text { million for the latest full year. } \\
\text { 3. net profits from operations in the year of } \\
\text { filing the listing application, when all } \\
\text { quarterly results from that year are } \\
\text { combined }\end{array}$ & 3 years \\
\hline $\begin{array}{l}\text { Hong } \\
\text { Kong }\end{array}$ & Common Law & Min 1,000 shareholders & $\mathrm{HK} \$ 200 \mathrm{~m}$ & 25.77 & & $\begin{array}{l}\text { Min. HK } \$ 50 \text { million in the last } 3 \text { financial } \\
\text { years (with profits of at least } \mathrm{HK} \$ 20 \\
\text { million recorded in the most recent year, } \\
\text { and aggregate profits of at least } \mathrm{HK} \$ 30\end{array}$ & 3 years \\
\hline
\end{tabular}




\begin{tabular}{|c|c|c|c|c|c|c|c|}
\hline & & & & & & million recorded in the 2 years before that) & \\
\hline $\begin{array}{l}\text { China } \\
\text { Shenzen }\end{array}$ & Civil Code & $\begin{array}{l}\text { Min. } 1,000 \text { shareholders with } 25 \% \text { public } \\
\text { free float }\end{array}$ & -- -- & -- -- & -- -- & $\begin{array}{l}\text { Profitable credit records over previous } 3 \\
\text { years with IPO being granted by the China } \\
\text { Securities Regulatory Commission. Min. } \\
\text { total issued and paid up share capital: RMB } \\
\text { 30M }\end{array}$ & 3 years \\
\hline $\begin{array}{l}\text { China } \\
\text { Shanghai }\end{array}$ & Civil Code & $\begin{array}{l}\text { Min. } 1,000 \text { shareholders with } 25 \% \text { public } \\
\text { free float }\end{array}$ & ---- & -- -- & -- -- & $\begin{array}{l}\text { Profitable credit records over previous } 3 \\
\text { years with IPO being granted by the China } \\
\text { Securities Regulatory Commission. Min. } \\
\text { total issued and paid up share capital: RMB } \\
\text { 30M }\end{array}$ & 3 years \\
\hline Philippines & Civil Code & $\begin{array}{l}\text { Min. 1,000 shareholders (sliding scale } \\
\text { between } 33 \% \text { to } 10 \% \text { free float to public } \\
\text { depending on amount issued) }\end{array}$ & P 50m & 1.13 & -- -- & $\begin{array}{l}\text { Cumulative consolidated pre-tax profit of at } \\
\text { least at least P50 Million and a minimum } \\
\text { pre-tax profit of P10 Million for each of the } \\
3 \text { full fiscal years immediately preceding } \\
\text { the application for listing }\end{array}$ & 3 years \\
\hline Japan & Civil Code & $\begin{array}{l}\text { Min. } 800 \text { shareholders (min. free float of } \\
30 \% \text { ) }\end{array}$ & Y 2b & 24.01 & ---- & $\begin{array}{l}\text { Cumulative consolidated pre-tax profit of at } \\
\text { least at least Y } 600 \mathrm{~m} \text { with this being Y } \\
100 \mathrm{~m} \text { in first year pre-listing and Y } 400 \mathrm{~m} \text { in } \\
\text { second year pre-listing }\end{array}$ & 3 years \\
\hline $\begin{array}{l}\text { South } \\
\text { Korea }\end{array}$ & Civil Code & $\begin{array}{l}\text { Min. } 1,000 \text { shareholders with } 25 \% \\
\text { distributed to public and minority } \\
\text { shareholders }\end{array}$ & KRW 10b & 8.68 & $1,000,000$ & $\begin{array}{l}\text { Recent year sales of at least KRW } 30 \\
\text { billion \& } 3 \text { year average sales of at least } \\
\text { KRW } 20 \text { billion \& Should realize recent } \\
\text { year operating profit }\end{array}$ & 3 years \\
\hline
\end{tabular}

